UNIVERSIDADE DE SÃO PAULO

ESCOLA DE ENFERMAGEM DE RIBEIRÃO PRETO

DEPARTAMENTO DE ENFERMAGEM GERAL E ESPECIALIZADA

PROGRAMA DE PÓS-GRADUAÇÃO - DOUTORADO

ÁREA ENFERMAGEM FUNDAMENTAL

\title{
A VIVENCCIA DO ENVELHECER: \\ SENTIDO E SIGNIFICADOS PARA A PRÁTICA DE ENFERMAGEM
}

\author{
Maria da Graça da Silva
}

Ribeirão Preto 
MARIA DA GRAÇA DA SILVA

\title{
A VIVÊNCIA DO ENVELHECER: \\ Sentido e significados para a prática de Enfermagem
}

\author{
Tese apresentada à Escola de Enfermagem de \\ Ribeirão Preto da Universidade de São Paulo, como \\ requisito parcial para obtenção do título de Doutor, \\ junto ao Programa de Pós-Graduação em Enfermagem \\ Fundamental.
}

ORIENTADORA: Prof ${ }^{a}$. Dr. ${ }^{a}$ Magali Roseira Boemer

\author{
ÁREA: ENFERMAGEM FUNDAMENTAL \\ DEPARTAMENTO DE ENFERMAGEM GERAL E ESPECIALIZADA \\ LINHA DE PESQUISA: PROCESSO DE CUIDAR DO ADULTO EM DOENÇAS \\ AGUDAS E CRÔNICO-DEGENERATIVAS
}

Ribeirão Preto 


\section{FICHA CATALOGRÁFICA}

Silva, Maria da Graça da

A vivência do envelhecer: sentido e significados para prática de enfermagem. Ribeirão Preto, 2007.

$173 \mathrm{f..;} 30 \mathrm{~cm}$.

Tese de Doutorado apresentada à Escola de Enfermagem de Ribeirão Preto/USP - Programa de Pós-graduação em Enfermagem Fundamental.

Orientador: Boemer, Magali Roseira

1. Idoso. 2. Enfermagem. Envelhecimento. 


\section{FOLHA DE APROVAÇÃO}

Maria da Graça da Silva

A vivência do envelhecer

Tese apresentada à Escola de Enfermagem de Ribeirão Preto da Universidade de São Paulo, como requisito parcial para obtenção do título de Doutor, junto ao Programa de PósGraduação em Enfermagem Fundamental.

Aprovado em:

\section{BANCA EXAMINADORA}

Profa. Dra.

Instituição: Assinatura:

Profa. Dra.

Instituição: Assinatura:

Profa. Dra.

Instituição: Assinatura:

Profa. Dra.

Instituição: Assinatura:

Profa. Dra.

Instituição: Assinatura: 


\section{DEDICATÓRIA}

Àqueles que já se foram, mas continuam presentes porque marcaram minha vida, preenchendo-a com amor: meu pai Benedicto, meus avós maternos Humberto e Maria Ferrante (Dona Zinha) e minha avó paterna Maria da Glória.

Aos idosos dos Centros de Convivência que freqüentei que, de uma maneira ou de outra, influenciaram na realização deste trabalho. Sem as suas colaborações, não chegaria ao fim. 


\section{AGRADECIMENTOS ESPECIAIS}

A $\boldsymbol{D E} \boldsymbol{U} \boldsymbol{S}$, Senhor da minha vida e ao seu Filho Jesus Cristo, na certeza de suas presenças em minha vida, amparo nas horas de desânimo, ouvidos inclinados a escutar minhas súplicas, lâmpada para os meus pés e luz para os meus caminhos do início ao fim desta jornada.

Ao meu esposo Sérgio, por sempre acreditar em mim e ter incentivado o cumprimento de mais uma etapa na minha vida acadêmica. Pelo amor e companheirismo constantes, sem os quais seria impossível terminar este trabalho.

A minha amada neta Rayane Cristina, presente divino na minha vida, com quem estou aprendendo a conjugar o verbo amar na sua plenitude.

A minha filha Iael Cristina, também enfermeira por opção, de quem tenho orgulho de ser mãe e que, mais uma vez, soube compreender minhas ausências e as viagens constantes.

A minha mãe Ednéa, que muito me ensinou sobre como envelhecer com esperança e independência. Pela acolhida incondicional no seu lar, durante minha presença em Ribeirão Preto.

\section{JAMAIS PODEREI RETRIBUIR TUDO O QUE FIZERAM POR MIM.}




\section{AGRADECIMENTOS}

À Professora Doutora Magali Roseira Boemer, pela orientação serena e segura, que possibilitou meu crescimento pessoal e profissional de modo tranqüilo, respeitando meu tempo.

Ás Professoras Doutoras Lúcia Hisako Takase Gonçalves, Regina Célia Popim, Adriana Kátia Corrêa e Maria Manuela Rino Mendes, pelas sugestões que enriqueceram meu trabalho.

A minha irmã Ligia, que me recebeu em seu lar por tantas vezes, respeitando meu cansaço e esforço para alcançar meu objetivo.

Aos meus irmãos Edmar e Ronaldo, minhas cunhadas Lúcia e Maria de Lourdes, pelo apoio e disposição para ajudar-me durante minha estadia em Ribeirão Preto.

À amiga Vilma Ribeiro da Silva, companheira de viagem e de estudos. Amizade fortalecida na convivência mais próxima durante este percurso.

Às amigas Maria Gorette dos Reis e Marisa Dias Rolan, companheiras de disciplina e com as quais pude dividir as angústias e conquistas neste caminhar.

Às colegas do Departamento de Enfermagem da Universidade Federal de Mato Grosso do Sul, pelo incentivo na busca da minha capacitação e pelo apoio durante meu afastamento do curso.

À Secretaria Municipal de Assistência Social de Campo Grande-MS, na pessoa da Sra. Lacy Severo Pupim, pela concessão do livre acesso às dependências dos Centros de Convivência, dando-me liberdade para desenvolvimento do projeto.

Ao coordenador do CCI "Elias Lahdo", Sr. Aymoré Alves Marinho, pela acolhida e respeito ao meu trabalho e incentivo para participar das atividades realizadas naquele local. 
Às assistentes sociais do CCI “João Nogueira Vieira”, Ana Cristina e Janete, pela receptividade e liberdade concedida para circular nas dependências do CCI.

À Nice, Maria Gorette, professores e aos demais funcionários dos Centros de Convivência pelo apoio na realização deste estudo.

À CAPES (Coordenação de Aperfeiçoamento de Pessoal de Nível Superior)- MEC, pelo apoio financeiro, sem o qual não seria possível realizar esta pesquisa.

Aos amigos da Igreja Presbiteriana do Bairro Amambaí, pelo interesse e respeito ao meu trabalho, compreendendo minha ausência em algumas atividades.

Às pessoas da Escola de Enfermagem de Ribeirão Preto da Universidade de São Paulo, pela oportunidade de convivermos mais uma vez juntos.

Agradeço a todos que apoiaram, direta ou indiretamente, a realização deste trabalho.

"Que Deus os abençoe e conduza a uma vida longa e com muita saúde" 


\section{Reinauguração}

Nossa idade - velho ou moço - pouco importa.

Importa é nos sentirmos vivos e alvoroçados

mais uma vez, e revestidos de beleza, a exata

beleza que vem dos gestos espontâneos e do

profundo instinto de subsistir enquanto as coisas

em redor se derretem e somem como nuvens

errantes no universo estável.

Prosseguimos. Reinauguramos. Abrimos olhos

gulosos a um sol diferente que nos acorda para

os descobrimentos.

Esta é a magia do tempo.

Esta é a colheita particular que se exprime no cálido abraço e no beijo comungante, no acreditar na vida e na doação de vivê-la em perpétua procura e perpétua criação.

E já não somos finitos e sós.

Carlos Drummond de Andrade 


\section{SUMÁRIO}

1. Revisitando o passado: a gênese das inquietações sobre o envelhecer..... 4

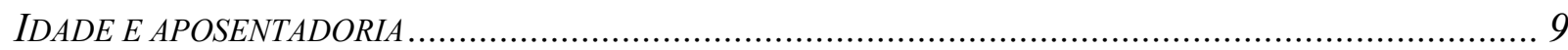

2. Falando sobre o envelhecimento humano ....................................... 15

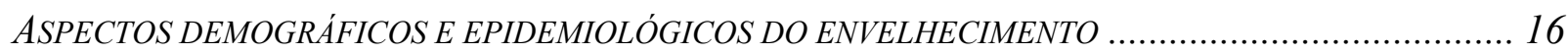

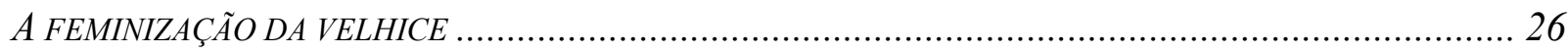

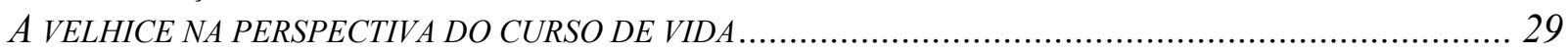

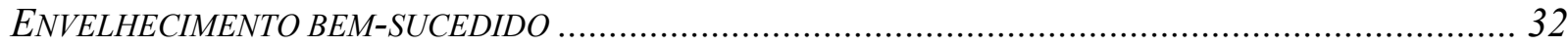

3. O caminhar metodológico............................................................ 41

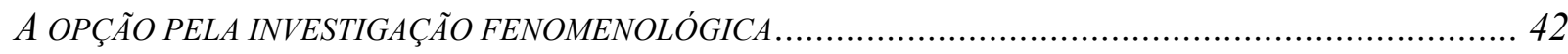

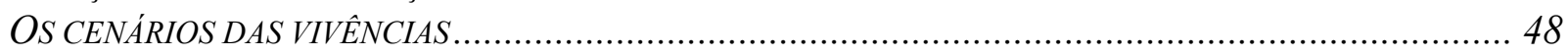

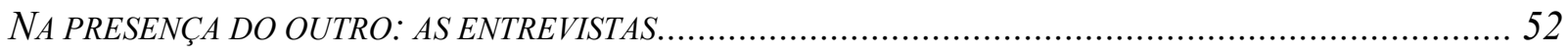

4. Os depoimentos das pessoas idosas................................................... 57

5. As possibilidades de ser com o envelhecimento.................................. 80

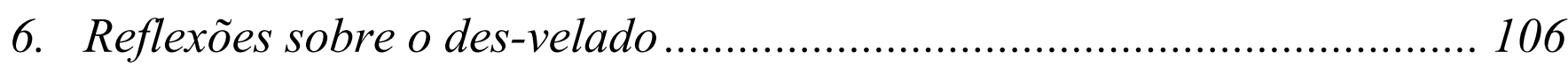

7. Sentido e Significados do Envelhecimento para a Prática de Enfermagem ...................................................................... 117

ALGUMAS CONSIDERAÇÕES SOBRE ENFERMAGEM GERONTOLÓGICA _......................................... 125

8. Referências.

Apêndices.

Anexos. 


\section{RESUMO}

SILVA, Maria da Graça da. A vivência do envelhecer: sentido e significados para a prática de Enfermagem. 2007. 149 f Tese (Doutorado) - Ribeirão Preto: Escola de Enfermagem de Ribeirão Preto da Universidade de São Paulo, 2007.

Neste estudo, de natureza qualitativa, conduzido segundo a abordagem fenomenológica, tendo como sujeitos as pessoas idosas, ou seja, com 60 anos de idade ou mais, freqüentadoras de dois Centros de Convivência do Idoso, localizados na cidade de Campo Grande, Mato Grosso do Sul, Brasil. busquei a compreensão da vivência do envelhecer. A opção pela fenomenologia se deu pelo fato da minha busca ser no sentido de compreender a experiência vivida pelo sujeito que está envelhecendo, descrevendo a mesma sob a perspectiva da pessoa idosa. Utilizei os recursos da entrevista fenomenológica, conforme proposto por Carvalho (1987), tendo como questão norteadora "Como é chegar a esta idade? Viver tantos anos?" Deste modo, ao interrogar qual o significado de viver até a chamada terceira idade, encontrei sentido para a prática de enfermagem voltada a essas pessoas que, talvez, possa contribuir para uma formação acadêmica mais humana, visando a assistência integral a este segmento populacional significativo na nossa sociedade, compreendendo quem é este ser humano a quem cuido. As principais preocupações das pessoas entrevistadas são mostrar que não perdem sua identidade por ficarem velhas e, às vezes, apesar da idade cronológica, não se sentem envelhecidas; esperam o reconhecimento enquanto cidadãs, reafirmam que ter saúde é essencial e as possibilita manter autonomia sobre suas vidas; enfatizam a importância do apoio, da convivência e do cuidado na família; valorizam a independência financeira e evitam falar sobre a finitude do ser humano.

Palavras Chave: enfermagem, envelhecimento, idoso. 


\begin{abstract}
SILVA, Maria da Graça da. The experience of the aging: sense and meanings for practice of Nursing. 2007. 149 f Thesis (Doctorate) - Ribeirão Preto/SP: School of Nursing of Ribeirão Preto of the University of São Paulo, 2007.

In this study, of qualitative nature, driven according to the sight phenomenological, we have as subjects the older person, with 60 years of age or plus, visitors of two Centers of Coexistence of the Elder, located in the city of Campo Grande, Mato Grosso do Sul, Brazil, I looked for the understanding of the existence of the aging. The option for the phenomenology felt for the need of understanding the experience lived by the subject that it is aging, describing that experience under the old person's perspective. Did I use the presuppositions of the interview phenomenological, as proposed by Carvalho (1987), establishing the following question "As it is to arrive that age? How is it to live so many years?" This way, when interrogating which the meaning of living to the call third age, I found sense for the practice of returned nursing the those people that, maybe, it can contribute to a more human academic formation, seeking the intere attendance to that significant population's segment in our society, understanding that he is of who we had the care. The main concerns of the interviewees were: to show that they don't lose their identity because they age and, sometimes, in spite of the chronological age, they don't feel old; they wait for the recognition while citizens, and it reinforces that to have the health it is essential and she makes possible to maintain the autonomy about their lives; they give emphasis to the importance of the support, of the coexistence and of the care in the family; the financial independence and they also value they avoid to talk about the human being's finite condition.
\end{abstract}

Key words: Nursing; Aging; Elder. 


\section{RESÚMEN}

SILVA, Maria da Graça da. La vivencia del envejecer: el sentido y significados para la práctica de la enfermería. 2007. 149 f Tesis (Doctorado) Ribeirão Preto: Escola de Enfermagem de Ribeirão Preto da Universidade de São Paulo, 2007.

En este estudio, de naturaleza cualitativa, conducido según la abordage fenomenologica, tenemos como informantes los ancianos, con 60 años de edad o más, los visitantes de dos Centros de Convivencia de la Persona anciana, localizados en la ciudad de Campo Grande, Mato Grosso do Sul, Brasil, que yo busqué la comprensión de la vivencia del envejecer. La opción para la fenomenología fué por la necesidad de entender la experiencia vivida por la persona que está envejeciendo, mientras describiendo esa experiencia bajo la perspectiva de lo anciano. Yo usé las presuposiciones del fenómeno de la entrevista, como propuesto por Carvalho (1987), estableciendo la pregunta siguiente "¿Como es llegar esa edad? ¿Como es vivir tantos años?" Así, al interrogar cual el significado de vivir a la llamada tercera edad, yo encontré el sentido para la práctica de la enfermería direccionada para aquéllas personas o que, quizá, puede contribuir a una formación académica más humana, mientras buscando la asistencia íntegra a ese segmento de la población significante en nuestra sociedad, entendiendo que ella es de quién nosotros tuvimos el cuidado. Las preocupaciones principales de los entrevistados eran: mostrar que ellos no pierden su identidad porque ellos envejecen y, a veces, a pesar de la edad cronológica, ellos no se sienten viejos; ellos esperan por el reconocimiento mientras ciudadanos, y refuerza que para tener la salud es esencial y hace posible mantener la autonomía sobre sus vidas; ellos dan énfasis a la importancia del apoyo, de la coexistencia y del cuidado en la familia; también valoran la independencia financiera y ellos evitan hablar sobre la condición finita del ser humano.

Palabras-llave: Enfermería; Envejecimiento; Anciano. 
1. Revisitando o passado: a gênese das inquietações sobre o envelhecer

"Na mocidade aprendemos, na velhice compreendemos".

Marie von Ebner-Eschenbach (1830-1916) Aforismos. 
$A$

iniciar a leitura deste estudo, alguém pode se perguntar o porquê do meu interesse por este tema - "envelhecimento". Para tanto, narro, ainda que de maneira resumida, como caminhei até aqui.

$\mathrm{Na}$ infância e na mocidade quase não pensava no envelhecimento como algo que pudesse atingir-me. "Velhos" eram os outros, os "caretas", aqueles que não compreendiam minha ânsia de viver intensamente cada minuto, que não acreditavam nos meus sonhos e tolhiam minha criatividade. Ou, então, eram os que me acalentavam e contavam histórias de seu tempo vivido.

Com o passar dos anos, na idade adulta, pensei que estava crescendo, mas ainda não envelhecendo. Na adolescência, defini minha opção pela profissão - Enfermagem- ao cuidar do meu avô materno, durante sua internação na fase crítica da doença que o levou à morte. $\mathrm{O}$ hospital tornou-se parte do meu cotidiano e, no momento da escolha no vestibular, não tive dúvidas, apesar de alguns protestos familiares.

No decorrer do curso, a certeza de ter feito a escolha certa só se fortalecia e, aos vinte e um anos, lá estava a enfermeira "padrão" da família. Minha vida pessoal foi se reconfigurando: casamento, filhos, mudança de cidade, outro Estado. Trabalhar, viver, estudar para buscar uma condição melhor, no âmbito profissional e financeiro.

O envelhecimento foi, então, mostrando-se cada vez mais nos outros: mãe, pai, tios, vizinhos. As perdas também passaram a ser quase freqüentes e mais próximas. A vida profissional voltada, praticamente em sua totalidade, para a clínica médica, começou a dar-me a visão de que ficar velho era sinônimo de doença e morte. Tal visão é facilmente entendida por quem conhece as pessoas que necessitam de atendimento nesta especialidade. Geralmente são idosos, com doenças crônico degenerativas, com internações prolongadas e alto índice de mortalidade. 
Minha vivência no setor hospitalar de Clínica Médica tornou expressiva esta visão, consolidando-a como se fosse a única perspectiva real ao envelhecermos. Atendendo o idoso apenas como "paciente" na instituição, desvinculava-o do contexto social e familiar, vendo-o fragmentado e limitado em suas possibilidades. As interrogações eram freqüentes: "de onde vem esta vontade de se curar e voltar para casa?"; "fazer mais o quê na vida, nesta idade?".

Gelain e cols (1997) reafirmam esta vivência, pois, ao pesquisarem aspectos éticos envolvidos na assistência de enfermagem às pessoas idosas, constataram que o setor de Clínica Médica de um hospital geral admite um grande número de idosos, com predominância de idades entre 60 e 64 anos e 70 a 79 anos, destacando-se um número significante de mulheres com mais de 80 anos e com doenças crônico-degenerativas. Os dilemas éticos puderam ser evidenciados nas seguintes questões: vale a pena investir todos os recursos disponíveis quando nada mais se tem a fazer?; devemos abandonar o idoso por não valer a pena investir? Vamos respeitar o curso da natureza, mas oferecendo conforto e apoio familiar?

Considero importante pontuar minhas experiências com idosos, pois dessas vivências foi configurando-se meu tema de pesquisa. As inquietações sempre foram muitas, uma vez que a proximidade com pessoas idosas ocorreu em momentos de doença e finitude. As queixas dessas pessoas eram constantes e eu sentia uma negação da vida, advinda da perda da saúde e pela dependência.

Porém, no cotidiano, isto era absorvido e contornado. As questões educativas da profissão tornaram-se prioridade e foram o foco da dissertação de mestrado, em 1997, uma vez que exerço a docência em um curso de graduação em enfermagem, desde 1993.

Passados os anos, os filhos crescidos, vislumbrei um novo panorama: estaria eu “envelhecendo"? Então, passei a questionar: "Seria isto a vida: sonhos realizados, frustrados, 
trabalho, doença e morte?" "Mas, apesar das mudanças fisicas, sinto que posso muito mais!"

Após vinte anos de exercício profissional, permanecia na Clínica Médica, tendo que lidar com a morte dos pacientes e com a resistência dos estudantes em aceitá-la. Passei a estudar o tema da morte, acreditando que, se esta é única certeza da vida, então melhor estar preparada para o fim e, quem sabe, auxiliar alguns outros a aceitarem-na.

Com este propósito, fui em busca de complemento espiritual, tanto religioso como humano e, em 2004, fiz o curso de Capelania Hospitalar, no qual pude estudar e debater vários temas da vida humana, dentre eles a morte.

Com a consolidação da minha crença pessoal e os estudos complementares, foi surgindo a dúvida: "Somos tão especiais e será mesmo que envelhecer significa somente adoecer e morrer?" "Haverá algo entre estes dois pólos?" "Então, o que é isto: o envelhecer?"

Nesse percurso, minha filha, então acadêmica de enfermagem, começou a desenvolver atividades práticas no Centro de Convivência do Idoso. Contava-me, então, dos "velhos" alegres, dispostos, cheios de vida e energia, ativos e que não se consideravam "idosos".

Assim, amadureceu a idéia de buscar compreender a esta vivência do envelhecer para aqueles que estão em condições consideradas mais favoráveis que outros. Para desenvolver tal proposta, inseri-me num programa de doutorado e optei por estudar este tema segundo a abordagem fenomenológica, partindo do vivido pelos sujeitos e não de teorias sobre o envelhecimento. Precisava buscar respostas, ainda que parciais, para ampliar os horizontes do meu fazer atual, como docente enfermeira, e vislumbrar outras possibilidades de se viver a velhice.

Nesse sentido, voltei-me, mais especificamente, para compreender o envelhecimento na perspectiva daqueles que estão em idade considerada "avançada", pois, minhas inquietações 
estão aí refletidas. Num primeiro momento, procurei assisti a diversos filmes que abordavam o tema sob vários enfoques e também busquei bibliografia diversificada.

Concomitantemente aos fatos mencionados, presenciei a polêmica da regulamentação dos planos de saúde, pois alguns, além do aumento abusivo das mensalidades vinculadas ao fator idade, apresentam cláusulas limitando alguns tipos de atendimento a essa faixa etária.

Hoje, principalmente nas sociedades ocidentais, ser idoso tornou-se sinônimo de imprestável, de fraqueza, doença e estorvo. Mais uma vez, a razão desta representação advém de raízes seculares, uma herança cultural negativa que acabamos herdando de nossos antepassados. Alguns povos consideravam o velho como algo inútil, já incapaz de produzir bons frutos para a sociedade, sendo muitas vezes abandonado nas montanhas ou à margem das estradas para aguardar a morte (SCHIRRMACHER, 2004).

Junqueira (1998, p. 37) refere que "a escassez de literatura científica brasileira e internacional sobre idosos faz com que predomine, desde a Antiguidade, o pensamento médico de velhice como sinônimo de doença, conferindo aos velhos a conotação de doentes ou incapazes."

Segundo Borini e Cintra (2002), na sociedade brasileira alguns "verbetes" são comumente utilizados para designar a idade na qual o envelhecer é mais notado: velho, idoso, terceira idade, melhor idade, idade madura. Considerando a construção social da velhice, essas autoras relatam que há diferenças no significado e na aplicação da cada termo. Ao "velho", são atribuídas as imagens de doença, solidão, inatividade; se a questão é jurídicolegal, emprega-se o termo idoso e, em se tratando de saúde e bem estar, o termo terceira idade/melhor idade é mais utilizado.

Porém, Debert (2000), quando faz um resgate histórico da condição social da pessoa idosa, diz que a tendência contemporânea é rever os estereótipos associados ao envelhecimento. Siqueira e cols. (2002) dizem que o termo "terceira idade" é uma construção 
das sociedades contemporâneas e vem sendo empregado por acreditar-se que é isento de conotações depreciativas e para atender aos interesses de um mercado de consumo emergente. Refere-se, em geral, àqueles idosos que ainda não atingiram a velhice em idade mais “avançada”, após 80 anos; estão na faixa dos 55 aos 70 anos, e incluem, fundamentalmente, pessoas que ainda têm boa saúde e tempo livre para o lazer e para novas experiências nessa etapa da vida.

Olievenstein (2001) diz que Terceira Idade é a idade em que tudo é possível, pois o corpo e o psiquismo estão ainda suficientemente vivazes para permitir a iniciativa, a felicidade, inclusive a possibilidade de realizar os sonhos de toda uma vida. Junqueira (1998) faz um alerta para que a expressão $3^{\mathrm{a}}$ idade não se torne apenas uma categoria específica e as pessoas deixem de ser vistas como tal, tendo que se comportarem de maneira pré-estabelecida por regras e normas impostas pela sociedade.

No cotidiano com as pessoas idosas foi possível perceber esta preocupação, pois elas lutam para serem tratadas e ouvidas como cidadãs e não como meros integrantes de uma categoria, pela qual outros falam e por ela respondem.

\section{Idade e aposentadoria}

A dureza da sociedade onde vivemos, dominada por uma exigência de produção e de eficiência, contribui para agravar o peso do envelhecimento. Esta exigência manifesta-se brutalmente quando o limite de idade obriga a aposentadoria (recolher-se ao interior da habitação, aos aposentos, ou seja, retirar-se do convívio social, marginalizar-se). A imposição da incapacidade para produção e a exclusão do ciclo de rentabilidade equivalem, para muitos, a uma condenação, sem apelo, à morte social (BASTIDE, 1999). 
Silvestre e cols. (1996), no entanto, relatam que não se deve temer a aposentadoria, se esta ocorre voluntariamente, com o indivíduo em bom estado de saúde, com um confortável rendimento e permanecendo socialmente ativo.

Pessoalmente, acredito que o idoso pode continuar sendo referência na família e até mesmo no ambiente de trabalho onde dedicou sua vida, podendo ainda descobrir novas fontes de criatividade, percepção e valorização de sua existência. Schirrmacher (2005) refere que a sociedade não pode prescindir das experiências, da autoconsciência, sabedoria e conhecimento das pessoas idosas.

Barbosa e Duarte (2001) alertam que a pessoa idosa, excluída da atividade econômica, em função da aposentadoria, sente-se improdutiva e passa a vislumbrar o próprio fim. Olievenstein (2001) lembra que, quando vêm os golpes das aposentadorias compulsórias, instalam-se, dissimuladamente, os sentimentos de inutilidade, de inferioridade. O que era para ser um meio de concretizar projetos, por outro lado, quando vem acompanhado de uma severa redução de renda, pode levar a uma depressão ou à negação de si mesmo.

Segundo Minayo e Coimbra Jr. (2002), a visão depreciativa dos mais velhos tem sido, através dos tempos modernos, alimentada profundamente pela ideologia "produtivista" que sustentou a sociedade capitalista industrial, para a qual se uma pessoa não é capaz de trabalhar e ter renda própria, sua existência de pouco ou nada serve para sua comunidade ou seu país.

Em 1982, a Organização das Nações Unidas (ONU) propôs um limite cronológico para o início da chamada Terceira Idade, baseado na média de idade da aposentadoria estabelecida na maioria dos países, o que induziu a associação entre velhice e aposentadoria, ainda que, na prática, isto nem sempre seja verdadeiro (JACQUES; CARLOS, 2002). Assim, a imagem do velho é associada com a não produção de bens e serviços e, portanto, inútil nos contextos sociais pautados pelo valor produtivo. 
Junqueira (1998) refere que o envelhecimento populacional desajustou a estrutura social do Brasil, principalmente quanto ao Sistema Previdenciário, o qual não estava preparado para o crescente número de aposentadorias. Devido a tal desajuste, o valor da aposentadoria não pôde manter-se nos níveis imaginados e, por questões financeiras, muitos idosos, após aposentarem-se, precisam voltar ao trabalho. $\mathrm{O}$ valor recebido pela aposentadoria pode ser a única fonte de renda da família, uma vez que o desemprego e o trabalho informal atingem grande parte dos demais membros da família, como filhos e netos. Veras (2002) confirma este dado, ressaltando que as famílias podem ter os mais idosos do clã como grande sustentáculo, pelo fato de possuírem aposentadoria e terem conseguido uma nova reinserção no mercado de trabalho.

Camarano (2002) refere-se à importância da aposentadoria na renda dos idosos e também a contribuição da mesma enquanto uma parcela importante da renda familiar. Salienta que, em 1998, enquanto apenas $8 \%$ da população brasileira eram idosos, em $26 \%$ das famílias encontrava-se pelo menos um idoso contribuindo financeiramente no orçamento familiar.

Silva (2005) menciona que a ajuda financeira do idoso no orçamento familiar pode ser um ponto positivo, desde que ele não seja explorado, mas seja visto como sujeito que tem uma contribuição social a oferecer.

Siqueira e cols. (2002, p. 902) ressaltam que a velhice, às vezes, é delimitada pela aposentadoria, considerada como um advento social, uma data administrativa, “... que marca a passagem da pessoa da categoria de trabalhador para a de ex-trabalhador; de produtivo para improdutivo; de cidadão ativo para inativo.” Salgado (1990, p. 14) também ressalta que a aposentadoria, “... decreta funcionalmente a velhice, ainda que a pessoa não seja velha sob o ponto de vista biológico". 
Ferrigno (2002) designa a aposentadoria como um fenômeno social, que lança a pessoa em uma condição estigmatizante, na qual ela é percebida como alguém incapaz, uma vez que nada mais tem a contribuir com sua força de trabalho. Esta imagem é reafirmada pelos preconceitos de incapacitação que atingem o corpo envelhecido.

Apesar disto, Debert (2000) lembra que, em um país como o Brasil, onde os direitos básicos do cidadão são tão desrespeitados, a universalização do direito à aposentadoria, mesmo não sendo superior a um salário mínimo, significou uma conquista social importante.

A velhice também é vista como sinônimo de degradação física e psicológica e a maioria das sociedades não se encontra capacitada para conviver com as limitações naturais, decorrentes do processo de envelhecer. Entretanto, esses conceitos são injustos, pois velhice não significa decadência. Exceto situações nas quais o corpo sofre limitações devido à doenças crônicas com agravos progressivos, o envelhecer é uma fase de grande riqueza e vitalidade do ser humano. É o momento em que a pessoa pode olhar para trás e perceber o quanto aprendeu com a vida. Errou e acertou, mas, acima de tudo, viveu. O envelhecimento nada mais é do que o curso natural da existência humana.

É fato que, se considerarmos o curso natural da vida, quanto mais se vive, mais perto da morte se está. Porém, mais importante que ter uma vida longa, é viver bem e morrer com dignidade.

Para Heidegger (2005, parte II), a idéia de temporalidade está ligada à finitude do homem no mundo, pois desde que nasce, ele já é suficientemente velho para morrer. A morte atravessa a existência e está "inacabada" ao final da jornada. Assim, também entendo que a longevidade está vinculada ao envelhecimento.

A existência humana compreende vários momentos, passando pela infância, adolescência, vida adulta, velhice e morte. O envelhecer é, então, considerado um processo normal e fisiológico da vida do ser humano e é, sem dúvida, a maior fase do desenvolvimento 
humano. Entretanto, estes momentos não são estanques, pois isto seria uma visão positivista do ciclo da vida. "Envelhecer, nos dias de hoje, não é exceção, é regra" (KOMATSU, 1996, p. 7).

Deste modo, ao interrogar qual o significado da vida longa como perspectiva do ser humano, espero encontrar sentido para a prática de enfermagem voltada a essa parcela da população idosa e contribuir para uma formação acadêmica mais humana, visando a assistência integral a este segmento populacional significativo na nossa sociedade.

Assim, a proposta deste estudo é compreender o significado de estar envelhecendo, na perspectiva das pessoas que vivenciam essa situação. Uma busca pela compreensão do sentido da existência humana, do existir mesmo de cada uma das pessoas entrevistadas.

Além disso, desejo contribuir para a produção do conhecimento em enfermagem no que se refere ao envelhecimento, disponibilizando os resultados deste estudo para reorientar o ensino, a pesquisa e a assistência de enfermagem, e, quem sabe, até mesmo subsidiar discussões de políticas públicas direcionadas aos idosos.

Após o exposto neste primeiro capítulo, sigo o seguinte percurso, como um viajante compromissado com a descoberta.

No capítulo 2, mostro a relevância de refletir sobre as questões do envelhecer, uma vez que tal tema tem sido estudado sob vários aspectos, considerando o comprovado envelhecimento demográfico e a inversão da pirâmide populacional. A temática é mostrada sob alguns destes enfoques, mas deixo claro qual a perspectiva abordada neste estudo.

No capítulo 3, descrevo minha trajetória metodológica, explicitando as etapas percorridas na construção do estudo. A descrição dos cenários das vivências mostra o mundo habitado pelas pessoas, sujeitos desta pesquisa, e como foi o estar - com elas. 
No capítulo 4, apresento os depoiemntos na íntegra, possibilitando olhar o "todo" de cada um. No capítulo 5, exponho a essência do estudo, explicitando as possibilidades de se viver o envelhecer, conforme captado nos depoimentos dos entrevistados.

No capítulo 6, meu olhar se detém nas implicações da compreensão do envelhecer para o cuidado de enfermagem no contexto deste estudo e finalizo, no Capítulo $7 \mathrm{com}$ minhas reflexões sobre o vivido, como enfermeira e pesquisadora,. 


\section{Falando sobre o envelhecimento humano}

"Nosso amor pela pessoa velha não deve ser uma opressão, uma tirania a inventar cuidados chocantes, temores que machucam. Façam o que bem entendam, cometam imprudências, desobedeçam conselhos. Libertemos os velhos de nossa fatigante bondade".

Paulo Mendes Campos (1922-) O anjo bêbado. 


\section{Aspectos demográficos e epidemiológicos do envelhecimento}

\section{$\int$ nicialmente, quero abordar as diferenças conceituais entre velhice,}

envelhecimento, envelhecer e idoso, considerando que são termos utilizados no contexto deste estudo. No consenso, envelhecimento é um processo natural que ocorre em todos os seres humanos, em qualquer momento da vida. Nele ocorrem alterações no organismo, nas relações, na capacidade de adaptar-se ao seu meio e na maneira de ser e agir.

Já velhice é definida como a etapa da vida do ser humano em que as alterações ocorridas no envelhecimento acentuam-se, sendo, portanto, o resultado deste. É delimitada por eventos de natureza múltipla, ocorrendo perdas psicomotoras e sociais (NERI, 2005).

Idoso, do ponto de vista cronológico e legal, que o classificam na realidade brasileira, é a pessoa com idade igual ou superior a 60 (sessenta) anos. (Lei n. 10.741, de $1^{\circ}$ de outubro de 2003). O conceito de idoso deve levar em consideração a idade cronológica da pessoa e o grau de desenvolvimento do país em que vive. Nos países desenvolvidos, a pessoa é considerada idosa ao completar 65 anos de idade e, nos países em desenvolvimento, aos 60 anos (ORGANIZAÇÃO MUNDIAL DA SAÚDE - OMS, 2005).

No entanto, para além do critério cronológico, é preciso ressaltar outros elementos que se mesclam com a idade cronológica e são determinantes para as diferenças entre os idosos. Gênero, classe social, saúde, educação, fatores de personalidade, história de vida e contexto sócio histórico marcam a heterogeneidade desta população (NERI, 2005).

Envelhecer, segundo a Organização Pan-americana de Saúde (OPS, 1993), é um processo seqüencial, individual, irreversível, não patológico, resultado do desgaste de um organismo maduro, próprio a todos os membros de uma espécie, de maneira que o tempo o torne menos capaz de fazer frente ao estresse do meio ambiente e, portanto, aumente sua 
possibilidade de morte. É um processo contínuo e progressivo, no qual ocorrem modificações morfológicas, funcionais, bioquímicas, sociais e psicológicas (DUARTE; LEBRÃO, 2006, p. 471).

O envelhecimento é um curso gradual, natural, universal, inexorável; estruturado ao longo do tempo. Caracteriza-se por mudanças e transformações em nível bio-psico-social (HEINSIUS, 2005).

Do ponto de vista biológico, o processo de envelhecimento normal implica em algumas mudanças estruturais no corpo; há uma substituição gradual do tecido muscular por tecido adiposo e, por isso, o idoso tem menor quantidade de massa magra. Há ainda diminuição da água corporal e da massa óssea, entre outras, que acabam levando a pessoa idosa a tornar-se frágil e susceptível à alterações internas e externas, como doença, calor ou frio excessivos, além do uso de medicamentos (ANTONELLI, 2004).

Durante este processo, ocorrem alterações que variam entre pessoas. O declínio de cada sistema orgânico sofre influência de múltiplos fatores (BARBOSA; DUARTE, 2001). O ritmo, a duração e os efeitos do envelhecimento estão relacionados às diferenças individuais e de grupos etários, dependentes de eventos de natureza genético-biológica, sócio histórica e psicológica (NERI, 2005).

Senescência ou senectude (de senex = velho; latim) é o processo fisiológico de envelhecimento, com transformações orgânicas, morfológicas e funcionais que ocorrem com o passar dos anos, porém com ausência de afecções biológicas ou psicológicas. A velhice patológica ou senilidade significa a presença de doenças crônicas ou outras alterações biológicas ou psicológicas que podem acometer e modificar a saúde dos idosos; é a decrepitude, com alterações físicas e, algumas vezes, mentais, isto é, o envelhecimento acompanhado de processos mórbidos (CIDRACK e cols, 2004; TOLEDO; DIOGO, 2003).

A figura 1 representa as fases do envelhecimento fisiológico e patológico. 


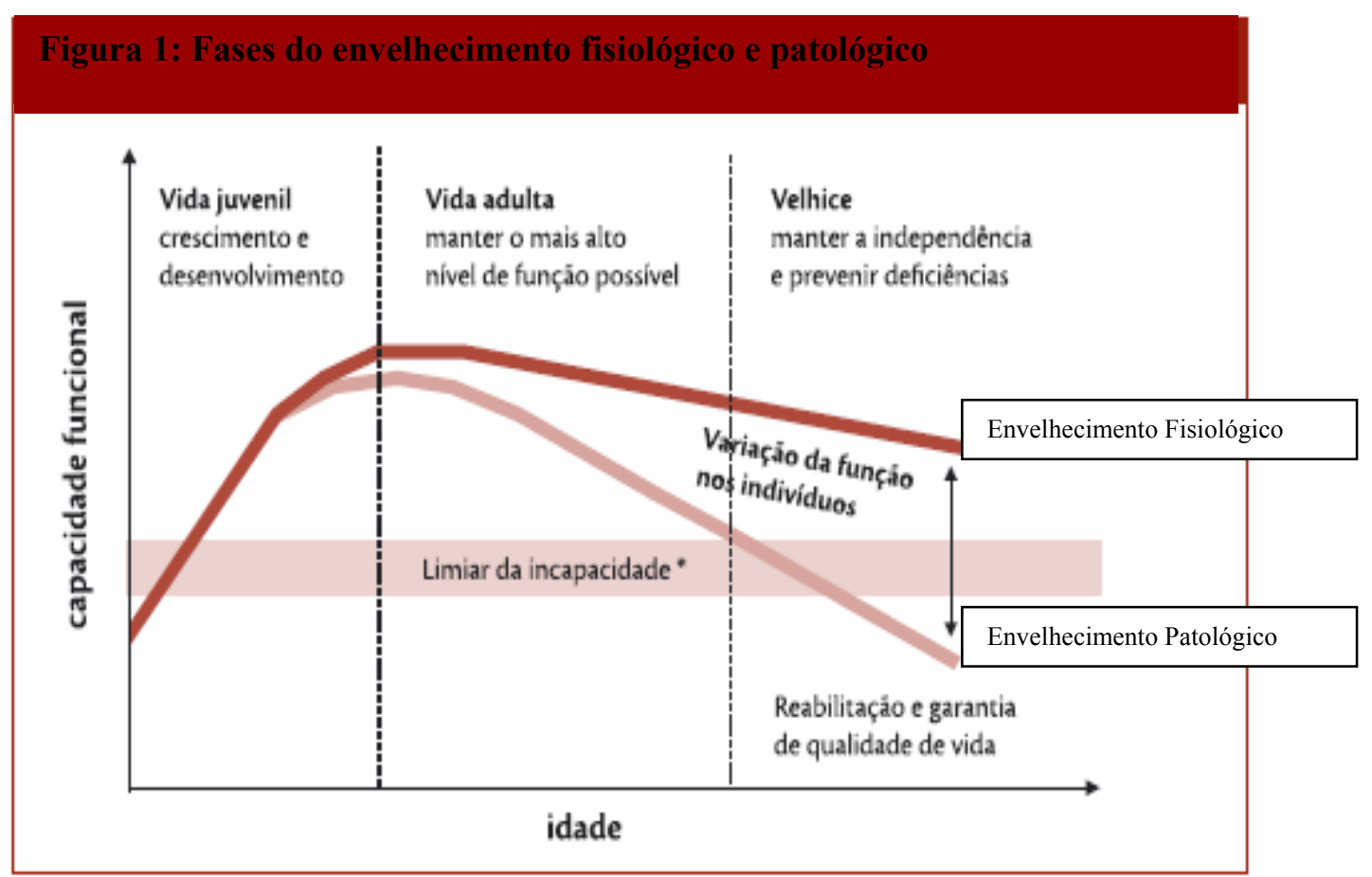

Fonte: Kalache and Kickbusch, 1997.

" Mudanças no ambiente podem diminuir o limiar da deficiéncia e, assim, reduzir o número de pessoas com incapacidades em uma comunidade.

Envelhecimento ativo: uma política de saúde/ World Health Organization; tradução Suzana Gontijo. - Brasília: Organização Pan-Americana da Saúde, 2005.

O envelhecimento fisiológico (senescência) é dividido em três estágios: envelhecimento bem sucedido, usual e frailty (envelhecimento com fragilidade). O envelhecimento bem sucedido diz respeito àquelas pessoas que conseguem chegar à velhice com independência e autonomia, mantendo suas funcionalidades biológicas e cognitivas, com perda fisiológica mínima, isentas de danos causados por hábitos de vida inadequados, ambientes inapropriados e doenças (MORAES, s/d).

O envelhecimento bem-sucedido e saudável depende da ausência de doenças e de fatores de risco para as mesmas (OPAS, 1998, p.9).

Segundo Neri (2005), um padrão de envelhecimento ótimo ou bem-sucedido estabelece-se quando a pessoa que envelhece preserva características e funcionalidade comparáveis às mais jovens, além da plasticidade comportamental, no momento em que seu funcionamento excede o de seus contemporâneos.

O envelhecimento usual mostra as alterações mais freqüentes do envelhecer, tanto do ponto de vista biológico quanto cognitivo, trazendo perdas, porém, mantendo, parcialmente, a 
autonomia e a independência. Apresenta prejuízos significativos, mas as pessoas não são qualificadas como doentes (MORAES, s/d).

O envelhecimento com fragilidade (frailty) também não é considerado "doença", mas requer atenção mais específica, pois os idosos considerados frágeis já apresentam alterações significativas para realização de atividades de vida diária, tanto básicas quanto instrumentais, são também mais susceptíveis a eventos patológicos e à incapacidades (MORAES, s/d).

O envelhecimento bem sucedido implica na ação de múltiplos fatores que determinam o bem estar na velhice. A saúde biológica é um dos mais poderosos preditores do bem estar na velhice, bem como a saúde mental, satisfação com a vida e com a família, a capacidade de iniciar e manter contatos sociais, o controle cognitivo, a produtividade, status social, renda, qualidade da habitação, continuidade de papéis familiares e ocupacionais, continuidade de relações informais em grupos, principalmente redes de amigos, a forma como o idoso lida com a morte, como valoriza seu passado, como faz uso de suas possibilidades atuais e as perspectivas de tempo futuro (ARAÚJO, 2007, p.1).

Por outro lado, pode ocorrer um envelhecimento patológico (senilidade), com associação de vários fatores (p.ex.: externos, co-morbidades, hábitos de vida), que levam à incapacidade da pessoa idosa, tornando-a dependente e insatisfeita com sua vida (MORAES, $\mathrm{s} / \mathrm{d})$.

Carvalho e Garcia (2003, p. 2) fazem a distinção conceitual entre longevidade e envelhecimento: "Longevidade refere-se ao número de anos vividos por um indivíduo ou ao número de anos que, em média, as pessoas de uma mesma geração ou coorte viverão, definindo-se como geração ou coorte o conjunto de recém-nascidos em um mesmo momento ou no mesmo intervalo de tempo."

Segundo Neri (2005, p. 40)

Uma coorte consiste num conjunto de pessoas nascidas na mesma época, que entram e saem juntas de seus sistemas ou instituições como, por exemplo, a escola e o trabalho - e que tendem a experienciar os mesmos eventos históricos, nas mesmas épocas de suas vidas. 
O envelhecimento populacional não se refere nem à pessoas, nem a cada geração, mas, sim, à mudança na estrutura etária da população, o que produz um aumento do peso relativo das pessoas acima de determinada idade, considerada como delimitadora do início da velhice (CARVALHO; GARCIA, 2003).

Segundo Jacques e Carlos (2002), a questão do envelhecimento vem ganhando representatividade, considerando o prolongamento da expectativa de vida da população e conseqüente crescimento do número de idosos em todo o mundo. Tavares (2005) refere que o “fenômeno demográfico de elevação da expectativa de vida e de maior proporção de idosos nas sociedades tem gerado espanto e suscitado debates sobre a velhice e o envelhecimento em todos os âmbitos...” e, por isso, tais questões estão em evidência na sociedade atual.

Quanto aos aspectos políticos e sociais, acredito que é dever da família, da sociedade e do Estado ampararem a pessoa idosa, garantindo-lhe o direito à vida. Cabe à família amparar os pais na velhice, carência ou enfermidade. O Estado deve garantir ao idoso o acesso aos bens culturais, participação e integração na comunidade, bem como liberdade e autonomia. Cada um, dentro de seus limites e responsabilidades, almejando o fortalecimento da unidade familiar.

Algumas políticas públicas visam o bem-estar do idoso, como por exemplo, o oferecimento do passe livre nos ônibus e metrôs, dispensa para o voto nas eleições para as pessoas acima de 70 anos, adaptação de acesso a dependências de órgãos públicos, entre outras. No aspecto educacional, as universidades para Terceira Idade, sejam em instituições públicas ou particulares, são locais de interação e encontros intergeracionais.

A Constituição Federal (BRASIL, Constituição, 1998) diz, no art. 230, que "a família, a sociedade e o Estado têm o dever de amparar as pessoas idosas, assegurando sua participação na comunidade, defendendo sua dignidade e bem-estar e garantindo-lhes o direito à vida". (site http://direitos_humanos.sites.uol.com.br/idosos.htm). Portanto, deve garantir ao idoso a 
proteção à discriminação de qualquer natureza e assegurar seus direitos de cidadania. Estabelecimentos comerciais, instituições públicas e privadas devem garantir-lhes este direito e privilégio.

A Lei 8.842, de 04.01.94, regulamentada pelo Dec. 1.958, de 03.07.96 (BRASIL. Leis, decretos, 1996) que dispõe sobre a Política Nacional do Idoso, tem como objetivos: assegurar os direitos sociais do idoso; promover a sua autonomia, integração e participação efetiva na sociedade $\left(\operatorname{art.} 1^{\circ}\right) ; \mathrm{O}$ art. $2^{\circ}$ considera que aos idosos, maiores de sessenta anos, devam ser assegurados: amparo social, garantia da cidadania, da participação, da informação e proibição de discriminação.

Dentre as diretrizes apontadas pela Política Nacional do Idoso, destacamos: viabilizar formas de participação e integração social; descentralizar a política administrativa; melhorar a capacitação técnica direcionada ao idoso; divulgar e informar sobre os idosos; priorizar o atendimento ao idoso e apoiar, educacional e cientificamente, as questões a eles relativas. (http://direitos humanos.sites.uol.com.br/idosos.htm). (grifos meus)

Destaquei esses dois pontos da legislação por que estão diretamente relacionados à proposta deste estudo, considerando que busco contribuir para a formação dos profissionais da enfermagem, não somente no aspecto técnico, mas, principalmente, humano.

Complementando esta política, vem a Lei 10.741 , de $1^{\circ}$ de outubro de 2003 , que dispõe sobre o Estatuto do Idoso, a qual considero uma grande conquista dos idosos, pelo menos no que se refere à legislação. O Estatuto, destinado a regular os direitos assegurados às pessoas com idade igual ou superior a sessenta anos (Art. $1^{\circ}$ ), aborda questões como educação, manutenção da renda, atendimento à saúde, garantia de transporte e locomoção, além de dispor sobre condutas relativas ao abandono, humilhação, discriminação e maus tratos impostos aos idosos. 
Silva (2005) reforça que estas legislações representam um avanço para o Brasil, pois, até 1970, as políticas desenvolvidas para o idoso tinham caráter paliativo e fragmentário. Agora o rumo parece ser outro, com as leis prevendo a garantia de direitos sociais e defendendo a causa do idoso sob vários aspectos.

Em conseqüência do aumento da expectativa de vida humana, praticamente em todas as partes do mundo, a população idosa vem constituindo-se em um segmento etário expressivo, gerando demanda também específica nos âmbitos social, político, econômico e da saúde. Segundo Schirrmacher (2005), nas próximas décadas, pela primeira vez na história da humanidade, o número de idosos será maior que o de jovens.

Para Siqueira e cols. (2002, p.900), o processo de envelhecimento populacional “...repercutiu e continua repercutindo nas diferentes esferas da estrutura social, econômica, política e cultural da sociedade, uma vez que os idosos, da mesma forma que os demais segmentos etários (crianças, jovens e adultos), possuem demandas específicas para obtenção de adequadas condições de vida". Segundo Bastide (1999), é uma classe de idade tornando-se uma categoria social, onde há perdas e ganhos.

Fogaça (1999) afirma que o tempo do envelhecimento é um dos períodos mais difíceis do ciclo da vida humana, por todo processo de perdas gradativas, o que exige de cada um e da sociedade, grande esforço de adaptação. Afirma também que, apesar da consciência que temos de que a vida é um processo global, traduzido por estágios sucessivos e modificações contínuas, que vão desde o nascimento até a morte, a velhice é significativamente desconsiderada (i.b., p. 206). Alerta para o fato de que a velhice tem seu lado ruim, mas não precisamos reforçá-lo. (i.b., p.207).

Schirrmacher (2005) refere que o reconhecimento de que ser velho não significa ser fraco ou frágil será uma das regras de sobrevivência de nossa sociedade ameaçada. 
O envelhecimento faz parte do curso natural da vida, mas não é fácil aceitar essa condição, pois envelhecer significa perder a capacidade de adaptação ao meio em que se vive e isso está associado à idéia de doenças, sofrimento e morte. As causas do envelhecimento e como ele ocorre ainda são um mistério para a ciência. Pesquisas na área são cada vez mais freqüentes. A expectativa de vida do homem aumenta a cada ano e o número de idosos está crescendo rapidamente no mundo. Existe uma preocupação com a qualidade do envelhecimento, ou seja, as pessoas querem envelhecer bem, com saúde e da maneira mais natural possível, tentando retardar ou minimizar as mudanças que ocorrem durante o processo de envelhecimento, e evitar doenças prevalentes numa parcela da população idosa (ex: doenças cardiovasculares, artrose, pressão alta, diabetes, vários tipos de câncer, demências tipo Alzheimer, etc.) (CASALI, 2004).

No Brasil, no início do século XX, a expectativa média de vida era de mais ou menos 34 anos; em 1950, passou a ser de 43 anos. No ano 2000, era de aproximadamente 69 anos e, em 2025, será de cerca de, 75 anos (SILVESTRE e cols., 1996; COELHO, 1999; DUARTE, LEBRÃO, 2006).

A proporção de idosos vem aumentando na população do Brasil e este processo de envelhecimento tem como explicação a continuidade do processo de declínio da fecundidade e, simultaneamente, o crescimento da esperança de vida, tanto dos homens como das mulheres. Quanto ao segmento populacional de 65 anos ou mais de idade, em função do processo de envelhecimento, todas as categorias revelam taxas de crescimento elevadas (INSTITUTO BRASILEIRO DE GEOGRAFIA E ESTATÍSTICA - IBGE, 2000, p. 38). O censo 2000 mostra um crescimento de 2,6\% na esperança de vida ao nascer da população brasileira, que passou de 66 anos, em 1991, para 68,6 anos em 2000 (PAVARINI e cols, 2005). 
A Tabela 1 apresenta a proporção de pessoas nos grupos etários de 0 a 14 anos, 15 a 59 anos e de 60 anos e mais, nos quatro últimos censos brasileiros. É evidente o rápido processo de envelhecimento, o qual só ficará estável após o término do declínio da fecundidade (CARVALHO; GARCIA, 2003).

Tabela 1: Brasil: distribuição proporcional (\%) da população, segundo grandes grupos etários - 1970, 1980, 1991 e 2000.

\begin{tabular}{l|cccc}
\hline $\begin{array}{c}\text { Grupo etário } \\
\text { (anos) }\end{array}$ & 1970 & 1980 & 1991 & 2000 \\
\hline $0-14$ & 42,10 & 38,24 & 34,73 & 29,60 \\
$15-59$ & 52,83 & 55,69 & 57,97 & 61,84 \\
$60 \mathrm{e}+$ & 5,07 & 6,07 & 7,30 & 8,56 \\
\hline TOTAL & 100,00 & 100,00 & 100,00 & 100,00 \\
\hline
\end{tabular}

Fonte: IBGE $(1970,1980,1991$ e 2000)

Mendes (1989), em sua dissertação de mestrado, no final da década de 80, fez uma revisão da perspectiva do envelhecimento populacional mundial, com projeções para o Brasil, incluindo análise das conseqüências do aumento da expectativa de vida para a sociedade brasileira, reafirmando a necessidade do desenvolvimento de pesquisas sobre o envelhecimento, sob os mais diversos ângulos: social, político, jurídico, cultural, ecológico, biológico, psicológico e outros.

A população brasileira com mais de 60 anos vem aumentando ao longo das décadas. $\mathrm{O}$ número de idosos (com 60 anos de idade) passou de 3 milhões, em 1960, para 7 milhões, em 1975 e 14 milhões, em 2002 (um aumento de 500\%, em quarenta anos). Estima-se que alcançará 32 milhões, em 2020, representando 15 a 16\% da população total (DUARTE, M. J. 1994; SILVESTRE e cols, 1996; BOSCOV, 2004; SILVA, 2005; MENDES e cols., 2005; DUARTE, LEBRÃO, 2006). Em países como a Bélgica, por exemplo, foram necessários cem anos para que a população idosa dobrasse de tamanho. 
Siqueira e cols. (2002), citando dados do IBGE, confirmam que, no Brasil, na década de 1970, cerca de 4,95\% da população brasileira eram idosos, percentual que se elevou para 8,47\%, na década de 1990, havendo a expectativa de alcançar 9,2\%, em 2010.

As proporções da população "mais idosa", ou seja, a de 80 anos ou mais, no total da população brasileira, também estão aumentando e em ritmo bastante acelerado. Esse tem sido o segmento populacional que mais cresce, embora ainda represente um contingente pequeno. De 166 mil pessoas, em 1940, o contingente "mais idoso" passou para quase 1,5 milhão, em 1996. Representava $11,7 \%$ da população idosa, em 1996 e 0,9\% da população total (CAMARANO, 2002).

Essas transformações mostram que, num período de sessenta anos (1960-2020), o grupo de idosos crescerá quinze vezes, enquanto a população geral crescerá cinco (DUARTE, LEBRÃO, 2006).

Segundo Lima-Costa e Veras (2003), o envelhecimento populacional é um dos principais desafios da saúde pública contemporânea. Este fenômeno ocorreu, inicialmente, em países desenvolvidos, mas, mais recentemente, é nos países em desenvolvimento tem ocorrido de forma mais acentuada.

As transformações físicas constituem-se no aspecto que mais se destaca quando falamos de envelhecimento, pois há o surgimento das rugas, dos cabelos brancos, lentidão da marcha, perda da memória, entre outras. Como negar o processo de envelhecimento quando nosso corpo começa a nos impor limites e seu funcionamento já não é o mesmo de outrora? E, de repente, nos vemos irremediavelmente velhos, sem saber como aconteceu e sem que tivéssemos nos preparado para tal.

$\mathrm{O}$ envelhecimento tem fatores intrínsecos relacionados à nossa condição genética e metabólica, além de fatores extrínsecos que dependem de condições ambientais e comportamentais. 
A maioria das pessoas tem medo de envelhecer; isto é um fato. Mas, também é fato que ninguém gostaria de morrer ainda jovem. Estamos diante de um dilema que pode ser trabalhado, principalmente, com informação e ação. Essa mudança no perfil etário da população vem ocorrendo devido a fatores sociais e ambientais, tais como, uma menor taxa de natalidade e um maior conhecimento científico acerca de doenças que provocavam a morte da pessoa ainda jovem, principalmente as infecto-contagiosas, cujo índice de mortalidade caiu após o advento das vacinas e dos antibióticos (ANTONELLI, 2004).

Paralelamente às modificações observadas na pirâmide populacional, doenças prevalentes na população mais idosa ganham maior expressão no conjunto da sociedade. Um dos resultados dessa dinâmica é uma demanda crescente por serviços de saúde. Aliás, este é um dos desafios atuais: escassez de recursos para uma demanda crescente. O idoso recorre mais aos serviços de saúde, as internações hospitalares são mais freqüentes e o tempo de ocupação do leito é maior quando comparado a outras faixas etárias. Em geral, as doenças dos idosos são crônicas e múltiplas, perduram por vários anos e exigem acompanhamento constante, além de cuidados permanentes, medicação contínua e exames periódicos (LIMACOSTA; VERAS; 2003). Junqueira (1998, p. 27) reafirma esta questão dizendo que “atualmente as mortes na $3^{\text {a }}$ idade são ocasionadas por doenças degenerativas, como o câncer, hipertensão, estresse ou pela própria ação do homem”.

\section{A feminização da velhice}

Outro aspecto a ser destacado, embora não seja o foco principal deste estudo, é a feminização da velhice, situação que Silvestre e cols (1996, p. 85) já haviam detectado em suas investigações.

Conforme diz Camarano (2002) há uma elevada taxa de crescimento da população feminina na velhice relativamente a do segmento masculino. A maior longevidade da 
população feminina explica esse diferencial na composição por sexo. Como conseqüência, quanto "mais velho" for o contingente estudado, maior a proporção de mulheres.

Esta autora analisa as conseqüências deste fato, considerando o contexto social, afirmando que, devido a esta longevidade, as mulheres estão mais sujeitas à deficiências físicas e mentais do que seus parceiros. Muitas moram sozinhas, especialmente quando são viúvas ou então vivem com parentes. No entanto, as mulheres idosas apresentam, em geral, uma tendência maior do que os homens a viverem sozinhas, pois pode ser um estágio temporário do curso de vida (viuvez, divórcio) e pode refletir preferências por esse modo de viver. Silvestre e cols relatam que a mulher é muito mais solitária na velhice do que o homem, pois, além de viver mais, casa-se mais jovem e , uma vez viúva, apresenta uma menor taxa de segundo casamento do que o homem viúvo (SILVESTRE e cols, 1996, p. 85).

Na verdade, a proximidade geográfica nem sempre pode ser traduzida por uma maior freqüência de contato com filhos ou netos. A proporção dos mais idosos vivendo sós é mais elevada do que a dos idosos jovens, sendo que este diferencial vem crescendo (CAMARANO, 2002).

Debert (1994) faz reflexões sobre o gênero feminino e a velhice, citando vários autores, com opiniões diversas sobre a situação da mulher idosa. Há autores que acreditam que as mulheres ainda são duplamente vulneráveis, por serem mulheres e idosas. No entanto, outros defendem um otimismo no envelhecimento feminino, pois acreditam que, para as idosas de hoje, tanto a velhice quanto a viuvez podem representar certa independência ou mesmo uma forma de realização.

O que deve ser considerado é que há diferenças entre homens e mulheres, nas idades mais avançadas da vida. A autora diz que o envelhecimento pode ser uma experiência radicalmente distinta para ambos. Continua discorrendo sobre a feminização da velhice, trazendo dados sobre a participação feminina nos programas para "terceira idade", como os 
centros de convivência e as universidades da terceira idade, onde a presença masculina não ultrapassa $10 \%$ da população que freqüenta esses locais. Refere também o maior entusiasmo das mulheres na realização das atividades propostas, contrastando com a atitude de reserva e indiferença dos homens (DEBERT, 1994).

A razão de sexo da população idosa é, assim, bastante diferenciada, sendo bem maior o número de mulheres. Em 1991, as mulheres correspondiam a 54\% da população de idosos, passando para 55,1\%, em 2000. Isto significa que para cada 100 mulheres idosas havia 81,6 homens idosos, relação que, em 1991, era de 100 para 85,2. Chama atenção também o fato de que, no ano de 2000, para cada 100 homens brasileiros entre 60 e 74 anos, havia 133 mulheres na mesma faixa etária. Tal diferença é explicada pelos diferenciais de expectativa de vida entre os sexos, fenômeno mundial, mas que é bastante intenso no Brasil, considerando que, em média, as mulheres vivem oito anos a mais do que os homens. A relação entre gênero e envelhecimento baseia-se nas mudanças sociais ocorridas ao longo do tempo e nos acontecimentos ligados ao ciclo de vida. A maior longevidade feminina implica em transformações nas várias esferas da vida social, uma vez que o significado social da idade está profundamente vinculado ao gênero (IBGE, 2000, p 15).

Papaléo Netto e cols (2006) fazem uma reflexão global sobre a "feminização" da velhice, apontando aspectos biológicos, sociais, demográficos e econômicos para esta realidade e alertam para o fato de que as mulheres, em seu conjunto, são mais pobres do que os homens, e isto, somado a outros fatores, pode constituir a tríade pobreza, doença e solidão.

De acordo com Lebrão (2006), a velhice é feminina e pobre, pois, 6\% dos idosos vivem com apenas um salário mínimo, 56,7\% deles, com até três salários mínimos e 33\% sequer fazem três refeições por dia. "Os países desenvolvidos, primeiro ficaram ricos e depois, velhos. Os nossos estão ficando velhos antes de serem ricos”, afirma a autora. Mas, se as mulheres têm uma sobrevida maior do que a os homens, esse período "a mais" é marcado por 
dificuldades, pois elas apresentam maior nível de vulnerabilidade social. Sua renda é menor do que a masculina e elas se casam, pela segunda vez, com menos freqüência.

Salgado (2002) discorre, com muita propriedade, sobre a questão da feminização da velhice, abordando o tema sobre vários aspectos, listando pontos positivos e negativos para situação atual da mulher idosa. Um fato que chamou minha atenção refere-se ao aumento da longevidade, tendo como conseqüência a existência de mais de uma geração de idosos em uma mesma família, e considerando que, socialmente, cabe à mulher cuidar da família, é possível que, no futuro, as mulheres velhas estejam cuidando de suas mães ou avós ainda mais velhas.

Segundo esta autora, é preciso que os formuladores de políticas públicas e os pesquisadores sociais, predominantemente homens, considerem os aspectos específicos da mulher idosa (SALGADO, 2002).

\section{A velhice na perspectiva do curso de vida}

Neste estudo, vejo o envelhecimento a partir da perspectiva do curso da vida, ou seja, como um processo gradual, envolvendo aspectos históricos, sociais e individuais, numa visão mais complexa e elaborada dos momentos da vida.

A teoria do curso da vida, elaborada por Baltes, difere dos estudos da existência humana cujo referencial é o ciclo de vida, que caracteriza as fases da vida como etapas cronológicas sucessivas, unilineares e universais, tais como infância, adolescência, maturidade e velhice, sem considerar particularidades sociais e culturais (DEBERT, 1994). Para esta autora, o curso da vida é um espaço de experiências abertas e não de passagens ritualizadas de uma etapa para outra (DEBERT, 2006).

Neri (2005) refere que o termo ciclo de vida é utilizado pela Psicologia com o sentido de sucessão de estágios ou idades do desenvolvimento individual e cita Erik Erikson (1963) 
como o autor que consagrou o termo nesta área, estabelecendo oito idades do ser humano (fase bebê, infância, idade do brinquedo, idade escolar, adolescência, idade adulta, maturidade e velhice). Na Sociologia, o termo é usado com o significado de repetição das experiências de desenvolvimento geração após geração, de estágios de história de vida de coortes etárias, de vida familiar e da coordenação entre o desenvolvimento individual e a história das instituições sociais. Na demografia, ciclo de vida descreve padrões de mudança de populações.

Outros autores citados por Neri, como Bühler (1935) e Levinson (1978), classificam a velhice como o último estágio do desenvolvimento humano, caracterizado pela contração e redefinição de papéis familiares e profissionais.

Segundo Mauad (1997), a teoria de curso de vida que se desenvolveu a partir dos anos 70, de orientação dialética, representa uma mudança em relação à perspectiva da velhice como um período de decadência. Esta teoria defende a idéia de que a velhice apresenta um equilíbrio entre ganhos e perdas, que pode ser alcançado por meio de diversos mecanismos.

Segundo Neri (2005), o paradigma de curso de vida focaliza o desenvolvimento humano do ponto de vista das inter-relações do desenvolvimento individual, familiar e societal ao longo do tempo. Além do critério da idade cronológica, há também critérios de classe social, etnia, profissão e educação que se entrelaçam para configurar a posição das pessoas e dos grupos na sociedade.

Assim, a infância, adolescência, vida adulta e velhice são fases construídas socialmente, por meio de normas e sanções etárias que determinam as exigências e as oportunidades de cada segmento etário na ordem social e que comportam diferenças históricas e geográficas.

Nessa perspectiva, a periodização da vida humana é um artifício social usado para organizar os cursos de vida individuais e da vida social. Assim, as fases do desenvolvimento humano são vistas como socialmente construídas, a partir da interação simbólica entre a pessoa e seu mundo. Portanto, a emergência de uma nova categoria etária, por exemplo, meia- 
idade, centenários, velhice avançada, vem, comumente, acompanhada de uma ideologia, originando novas necessidades e oportunidades sociais e condicionando o estabelecimento de novas políticas sociais, abrindo, assim, espaço para a criação de novas instituições e organizações sociais.

Há que se considerar que nas classes sociais mais abastadas, existe uma indústria do turismo específica para pessoas idosas, além da opção de moradia em habitações planejadas com arquitetura própria para esta população.

Silva e Günther (2000) lembram que a teoria de curso de vida enfatiza a importância da seleção de prioridades e que é preciso sedimentar, na sociedade, a cultura positiva da velhice, na qual a pessoa idosa tenha projetos que não envelheçam. Compreendo que a realização dos projetos pessoais está diretamente relacionada aos recursos disponíveis, à possibilidade de inserção social, às condições de sobrevivência e respaldo familiar de cada pessoa.

O curso de vida humana é muito mais que um resultado inevitável da biologia e o envelhecimento não pode ser visto apenas como um processo de perdas e limitações. O desenvolvimento humano e, consequentemente, o envelhecimento, refletem a influência da genética e da cultura. Ao longo da vida acumula-se um conhecimento sobre a condução e o sentido da existência e, sob condições favoráveis, fica organizado de modo a poder transformar-se em algo muito especial: "Sabedoria". Este conhecimento pode ser poderoso o bastante para compensar, ao menos em parte, as perdas biológicas. Em alguns casos, a cultura pode exceder os limites biológicos.

A inteligência mecânica, como um processamento básico da informação, declina com o passar da idade; já a inteligência pragmática, como conhecimento cultural, pode manter-se até o final da vida. (http://www.mabesa.com.br/dicas_saude03.htm) 
Neri (2005) corrobora este pensamento referindo que as capacidades do ser humano cuja manutenção e aperfeiçoamento dependem de influências culturais, podem conservar-se e especializar-se, manifestando-se nos domínios profissional, de lazer, das artes ou do manejo das questões existenciais (sabedoria).

A sabedoria é apontada como ganho típico da velhice e vista como produto da influência da cultura e da educação. É um tipo de conhecimento especializado, indicador da possibilidade de continuidade do desenvolvimento intelectual na velhice. Culturalmente, a sabedoria é identificada como um conhecimento superior a respeito de questões difíceis da existência e como uma capacidade maior de aconselhar. (MAUAD, 1997).

A autora cita que, ao tentar defini-la operacionalmente, Baltes e seus colaboradores a resumem como uma forma de desempenho intelectual altamente especializado e especificam as características de elevado conhecimento factual e de procedimentos, capacidade de considerar o contexto, capacidade de relativizar valores e circunstâncias e capacidade de levar em conta a incerteza, em situações-problema, envolvendo revisão, planejamento e manejo de vida.

Guerreiro e Rodrigues (1999, p. 67) dizem que "a grande variabilidade de atitudes em face das situações de vida e o modo particular com que certos indivíduos encaminham positivamente as suas histórias, remetem-nos à reflexão sobre o desenvolvimento da sabedoria no curso de vida."

\section{Envelhecimento bem-sucedido}

Acredito que o desenvolvimento de programas educativos voltados à comunidade, ao idoso e sua família, bem como atividades de lazer, ginástica, trabalhos manuais e os grupos da terceira idade, vêm promovendo a cidadania dos idosos, valorizando seu saber e mantendo-os integrados à sociedade. A este respeito, podemos citar Mendes (1996) que relata uma experiência com a comunidade, através do Programa de Integração Comunitária - PIC, 
vinculado a uma Unidade Básica de Saúde, no município de Ribeirão Preto - SP, pelo qual a clientela atendida, na maioria, mulheres, com idade entre 35 a 80 anos, desenvolve atividades físicas, esportivas, recreativas e culturais. Os encontros são realizados em praça pública, no período matutino, durante uma hora, três vezes na semana. Os objetivos do programa incluem a melhora da qualidade de vida do adulto, prevenção de doenças crônicas e ajuda na eficácia e eficiência do tratamento das pessoas portadoras de doenças crônicas.

Os benefícios alcançados, conforme citados pela autora, são muitos, entre eles, efeito terapêutico da convivência entre os participantes, possibilitando o alívio do estresse, da fadiga e mudança na rotina cotidiana, além da valorização e melhora da auto-estima e engajamento político, inclusive com a inserção de uma representante do bairro junto ao Conselho de Defesa dos Direitos da Mulher. A educação em saúde também é contemplada, por meio de palestras e cursos oferecidos à comunidade.

$\mathrm{Na}$ igreja que freqüento, estou inserida, como colaboradora, no Grupo de Apoio a Melhor Idade - GAMI, que, no ano de 2003, passou a desenvolver atividades voltadas para os membros idosos. Eles podem praticar exercícios físicos, participar de passeios, palestras com profissionais de diversas áreas, além de cultivarem o aspecto espiritual e religioso, com o apoio da equipe pastoral.

Debert (1999) refere que tais iniciativas de socialização das pessoas idosas encorajam a busca de auto-expressão e a exploração de identidades e também abrem espaços para que uma experiência inovadora possa ser vivida coletivamente.

Entretanto, apesar dessas iniciativas, ainda há um longo caminho a percorrer no que tange à dignidade das pessoas idosas e a postura de inclusão que a sociedade precisa ter com elas.

Como explicitado, o envelhecimento populacional é realidade nas sociedades atuais e, como profissional de saúde, não posso manter-me alheia a essa problemática. Segundo 
Junqueira (1998), há necessidade de prestarmos assistência ao idoso devido, principalmente, a este aumento populacional que exige soluções dos profissionais de todas as áreas, especialmente da área da saúde. Para esta autora, o crescimento expressivo da longevidade aponta para a necessidade de compreendermos a velhice e suas conseqüências, tanto no âmbito individual, quanto no social.

A velhice e o envelhecimento têm estado em pauta desde a Antigüidade, abordados em obras literárias e tratados eruditos, como por exemplo, a obra De Senectude, de Cícero, escrita há cerca de dois mil anos. Porém, somente no século XX, vimos a emergência e a consolidação do estudo sistemático do envelhecimento, de cunho científico, denominado Gerontologia (GOLDSTEIN, 1999).

Essa autora analisou 232 trabalhos, realizados por pesquisadores brasileiros, sobre o tema envelhecimento, em diversas áreas do conhecimento, sendo 188 dissertações de mestrado, 39 teses de doutorado e 5 teses de livre docência, sendo que três teses de doutorado e duas dissertações de mestrado foram realizadas por pesquisadores brasileiros, em Universidades do exterior e as outras, em Universidades brasileiras.

No entanto, se hoje se percebe, especialmente no exterior, um grande aumento no número de estudos sobre o envelhecimento, já que, entre 1900 e 1940, pouco foi pesquisado sobre vida adulta e velhice. Na verdade, esses foram anos em que os estudos sobre a criança estiveram em grande expansão. Quanto à idade mais avançada da vida adulta, continuou-se investindo e fortalecendo pressupostos estabelecidos desde o século XIX, que diziam respeito à estagnação do desenvolvimento nesse período e ao caráter involutivo da velhice (GOLDSTEIN, 1999).

Pesquisadores do Centro Médico, da Universidade de Leiden, avaliaram um grupo de pessoas com idades acima de 85 anos para definir o que é ser idoso, utilizando dois critérios: 
um baseado em dados de saúde pública para o funcionamento físico, social e cognitivo e outro abordando a perspectiva dos próprios voluntários sobre o que seria envelhecer com sucesso.

Os cientistas descobriram que apenas $10 \%$ dos participantes satisfaziam todos os critérios e poderiam ser classificados na categoria de envelhecimento bem-sucedido, mas que $45 \%$ das pessoas avaliadas possuíam excelentes dados de bem-estar. Os resultados revelaram ainda que a maioria dos idosos via um envelhecimento bem-sucedido mais como um processo de adaptação, segundo relataram os autores do estudo, publicado na edição de dezembro da revista Archives of Internal Medicine, da American Medical Association (VON FABER e cols., 2001).

Os idosos estudados reconheceram os vários domínios de envelhecimento bemsucedido, mas valorizaram o bem-estar e o funcionamento social em detrimento do físico e cognitivo. A parte qualitativa do estudo mostrou que a proporção de idosos que perceberam ter envelhecido com êxito era muito mais alta.

Da perspectiva dos participantes, os diferentes domínios que constituem um envelhecimento bem-sucedido foram reconhecidos. No entanto, eles consideraram os contatos sociais como sendo o requisito mais importante para o bem-estar e, como uma conseqüência, para um bom envelhecimento. O trabalho conclui que a ausência de limitações e perdas não constitui o sucesso de um idoso. O sucesso é aferido pela forma como essas limitações e perdas são integradas com as posturas de uma pessoa em relação ao seu envelhecimento.

Junqueira (1998) refere pesquisas que compararam diversas faixas etárias e condições socioeconômicas e confirmaram a heterogeneidade das experiências da velhice no Brasil, concluindo que a pessoa idosa brasileira não existe, mas existem várias realidades de velhice, relativas às diferentes condições de vida.

Prado e Sayd (2004a) relatam o levantamento que realizaram para elaborar o Base Teses, uma base de grande importância no Centro de Referência e Documentação sobre 
Envelhecimento (CRDE), da Universidade Aberta da Terceira Idade (UnATI) - programa vinculado à Sub-Reitoria de Extensão e Cultura da Universidade do Estado do Rio de Janeiro (UERJ). As consultas aos bancos de dados foram realizadas através das seguintes palavraschave: velho, velhice, envelhecimento, idoso, aposentadoria, asilo, gerontologia e geriatria e a expressão terceira idade.

Os trabalhos elegíveis corresponderam a dissertações de mestrado, teses de doutoramento, trabalhos apresentados em provas de livre docência e concursos para professor titular em instituições acadêmicas no país e do exterior. Foram considerados também alguns poucos trabalhos que não se enquadram nesse perfil, mas cuja relevância histórica ou sua importância como referência para outros trabalhos justificam a inclusão.

Segundo as autoras mencionadas, até novembro de 2002, foram listadas 891 referências. Destes trabalhos, cerca de $76 \%$ correspondem a dissertações de mestrado e $21 \%$ são teses de doutorado, concentrados, em sua maioria (cerca de 90\%), em instituições das regiões sul e sudeste do Brasil. O amplo leque de abordagens da pesquisa científica para as questões relativas ao envelhecimento foi confirmado, com predominância das Ciências da Saúde, que responde por quase metade dessa produção científica. Seguem-se as Ciências Humanas e as Sociais e Aplicadas que, juntas, abarcam 30\% dos trabalhos. Dentre os trabalhos analisados, notou-se a importante contribuição da Medicina $(117 ; 13,1 \%)$, da Enfermagem (96; 10,8\%) e da Saúde Coletiva (88, 9,9\%).

Prado e Sayd (2004a) concluem que o envelhecimento, os idosos e a velhice são temas que ganharam recentemente a atenção dos mais diversos setores da sociedade. Nos meios acadêmicos, a produção de dissertações e teses confirma essa afirmativa: a década de 1990 registrou um crescimento quase sete vezes maior de conclusão de trabalhos em nível de pós- 
graduação stricto sensu que a década anterior e a tendência de crescimento parece manter-se, ao menos, até o momento.

Em outro estudo acerca dos grupos de pesquisa que operam no Brasil, as mesmas autoras buscaram contribuir para o conhecimento das características da produção sobre o processo de envelhecimento humano, no cenário nacional (PRADO; SAYD, 2004b). Os grupos de pesquisa foram identificados pelas palavras-chave: idoso(a)(s) ou velho(a)(s) ou velhice ou envelhecimento ou geriatria ou gerontologia ou aposentadoria e pela expressão terceira idade.

Na primeira etapa, foi estabelecida uma base de dados de 144 grupos de pesquisa que têm, pelo menos, uma linha de pesquisa que se refere ao envelhecimento humano. Isto significa que há, neste conjunto, grupos que se dedicam especificamente ao tema em questão, além de grupos que estão centralmente voltados para outras áreas de interesse e que também mantêm produção de conhecimento relativa ao envelhecimento humano. Aos 144 grupos de pesquisa correspondem 610 linhas de pesquisa. Para 43 grupos específicos há 92 linhas de pesquisa; a estas é necessário agregar mais 117 linhas que são aquelas enunciadas nos grupos não especificos e que trazem registradas as palavras-chave utilizadas na busca. São, portanto, 209 as linhas de pesquisa descritas pelos líderes como ativas na geração de conhecimento relativo ao envelhecimento humano no Brasil.

A pesquisa relativa à velhice, ao velho e ao processo de envelhecimento ocorre, predominantemente, na área das ciências da saúde, com importante participação das ciências biológicas. As ciências humanas e as sociais aplicadas também desempenham papel importante nas pesquisas relativas à temática. De fato, o envelhecimento humano interessa a pesquisadores de muitos campos da produção de conhecimento. Quanto ao estudo do processo de envelhecimento humano, o olhar das ciências da saúde e das ciências biológicas é aqui muito mais intenso, materializado, principalmente, por meio da saúde coletiva, da medicina, 
da enfermagem e da odontologia que, em seu conjunto, correspondem a $30 \%$ do universo da investigação realizada (PRADO; SAYD, 2004b).

Em um estudo específico da produção científica sobre envelhecimento e saúde no Brasil, Prado e Sayd (2004c) consultaram a Base LILACS - Literatura Latino-Americana e do Caribe em Ciências da Saúde, desenvolvida pelo Centro Latino Americano e do Caribe de Informação em Ciências da Saúde, identificando, principalmente, artigos publicados na área da saúde sobre o tema envelhecimento. Novamente constataram que os principais conteúdos correspondem a especialidades médicas (cardiologia, psiquiatria e neurologia), mas também há aqueles que correspondem a outras áreas do conhecimento como enfermagem, saúde pública ou epidemiologia, por exemplo.

As autoras constataram que as questões relativas aos idosos, à velhice e ao processo de envelhecimento e saúde vêm sendo, predominantemente, estudadas pelo viés das diversas especialidades médicas e não especificamente pela Gerontologia (PRADO; SAYD, 2004c).

A ampliação do tempo de vida foi, sem dúvida, um dos maiores avanços da humanidade, que se fez acompanhar de uma melhora substancial dos parâmetros de saúde das populações, ainda que essas conquistas estejam longe de se distribuir de forma eqüitativa nos diferentes países e contextos sócio-econômicos. Chegar à velhice, que era antes privilégio de poucos, hoje passa a ser a norma, mesmo para países mais pobres (LIMA- COSTA; VERAS, 2003).

Esta conquista, no entanto, torna-se um grande desafio para o terceiro milênio. O envelhecimento da população é uma aspiração natural de qualquer sociedade, mas não basta por si só. Viver mais é importante desde que se consiga agregar qualidade aos anos adicionais de vida. Dessa forma, surgem os seguintes desafios para a Saúde Pública, reconhecidos pela Organização Mundial da Saúde, que se traduzem como minhas inquietudes: 
- como manter a independência e a vida ativa com o envelhecimento?

- como fortalecer políticas de prevenção e promoção da saúde, especialmente aquelas voltadas para os idosos?

- como manter elou melhorar a qualidade de vida com o envelhecimento?

Juntamente com estes desafios, retomo meu questionamento: o que é isto, o envelhecer?

Figueiredo e Tyrrel (2005), após levantamento bibliográfico minucioso da produção científica de enfermagem no período de 1979 a 1999, constataram que a produção de enfermagem referente à terceira idade ainda era pequena. Os trabalhos existentes apresentavam-se marcados pelos referenciais positivistas predominantes no contexto histórico em que as pesquisas foram realizadas, com forte valorização da abordagem quantitativa, enfocando principalmente aspectos biológicos do ser humano numa perspectiva funcionalista.

Os enfoques sociais e culturais, característicos dos referenciais das ciências humanas e sociais, não eram, até então, considerados como relevantes nas investigações em saúde e mais especificamente, na área de enfermagem, principalmente, em relação a uma temática relativamente nova para sociedade brasileira, como a da terceira idade... (FIGUEIREDO;TYRREL, 2005, p. 332)

Dentre vários questionamentos elencados por Mendes (1989), em seu trabalho sobre o ensino da enfermagem gerontológica e geriátrica, reitero aquele que, acredito, continua requerendo resposta: estão os enfermeiros (acrescento aqui, a equipe de enfermagem) motivados/preparados para intervir na temática da pessoa idosa e atender às transformações que o envelhecimento populacional provoca em seu processo de trabalho? A autora contribui na busca de respostas propondo uma nova maneira de abordar o tema nos cursos de graduação em enfermagem.

Assim como gestantes e pessoas portadoras de necessidades especiais, o idoso deve ter direito ao atendimento preferencial nos postos de saúde e hospitais, devendo, estes últimos, 
serem adaptados para o seu atendimento. Sem esquecer que a assistência de enfermagem aos idosos não se restringe ao âmbito das instituições hospitalares, indo para além destes limites, envolvendo outros tipos de entidades, públicas e privadas, que prestam serviços de saúde (MENDES, 1989).

Segundo Lima - Costa e Veras (2003) é preciso encontrar os meios para incorporar os idosos em nossa sociedade, mudar conceitos já enraizados e utilizar novas tecnologias, com inovação e sabedoria, a fim de alcançar, de forma justa e democrática, a eqüidade na distribuição dos serviços e facilidades para o grupo populacional que mais cresce em nosso país.

O Brasil é um país que está envelhecendo. A cada ano, mais 650 mil idosos são incorporados à população brasileira. Muito tempo foi perdido, acreditando-se que ainda éramos um país jovem, sem dar o devido crédito às informações demográficas que mostravam e projetavam o envelhecimento da população brasileira. 


\section{O caminhar metodológico}

“O velho não pode ser pensado como uma folha apagada pelo tempo."

(GUSMÃO, 2003, p. 24) 


\section{A opção pela investigação fenomenológica}

enho assistindo a idosos há mais de dezesseis anos, pois minha vivência profissional tem sido relacionada a setores como Oncologia, Unidade Renal e Clínica Médica, cuja clientela, na instituição a qual estou vinculada, é caracterizada, em sua maioria, por pessoas idosas. Além da experiência nesses setores hospitalares, quando estive atuando na Secretaria Municipal de Saúde de Campo Grande - MS, minha proximidade sempre foi com essas pessoas, com a qual tenho prazer em atuar. Nesse exercício profissional, percebi minha necessidade de aprofundar conhecimentos acerca das questões que envolvem o idoso e o processo de envelhecer.

Como profissional, percebo uma expansão do papel da enfermagem na assistência aos idosos, atuando na prevenção, promoção e reabilitação dessas pessoas, além da ênfase atual no atendimento domiciliar e na integralidade da assistência, na busca pela melhoria da qualidade de vida.

Considerando o conhecimento adquirido pela literatura existente sobre o assunto e meu convívio junto a pessoas idosas, acredito que venho apreendendo algumas especificidades e singularidades interligadas ao envelhecer. Entretanto, falta-me a compreensão do que é "estar envelhecendo" na perspectiva de quem vivencia esse processo. Essa dimensão do envelhecimento permanece obscura, oculta.

A convivência com idosos saudáveis ou com problemas de saúde levou-me a refletir sobre este tema, pois observo divergências acerca do que significa velhice/envelhecimento para essas pessoas e também para seus familiares e cuidadores. Observei que o idoso é descrito pelo outro e não por ele próprio, como alertam Siqueira e cols.(2002). 
Minha proposta é aproximar-me de facetas da essência do processo de envelhecer, contribuindo, assim, para a assistência de enfermagem a essas pessoas. Espero compreender o envelhecimento a partir da experiência vivida de cada sujeito, como eles se mostram nas suas relações, com sua consciência como emoções e sensações. Optei por seguir a abordagem fenomenológica, pois concordo com Lopes e cols. (1995, p.51) quando referem:

Acreditamos que o referencial fenomenológico possa contribuir na busca de compreensão do humano de quem cuidamos, homem sujeito desse cuidado. Profissional e cliente são ambos sujeito e objeto, que se completam e vivenciam a possibilidade de uma interação.

$\mathrm{Na}$ escolha desta abordagem, encontrei respaldo também em Siqueira e cols. (2002) quando ressaltam que a velhice é um fenômeno rico e complexo, que encerra uma pluralidade de experiências individuais, podendo ser investigado sob várias perspectivas, mas, como pesquisadores, somente nos aproximamos de determinados aspectos que o compõem.

Compreendo, assim como Figueiredo e Tyrrel (2005, p. 333), “...a necessidade e a demanda de problemas a serem investigados pela enfermagem com a utilização de referenciais inovadores capazes de enfocar o ser humano de maneira integral, tendo também como base suas vertentes sociais, culturais e psicológicas."

Espero encontrar alguns caminhos que possam ajudar a discutir, com mais liberdade e fundamentação, aspectos do envelhecimento humano, com vistas à transformação, desconstrução e reconstrução de políticas públicas que contemplem esse momento do existir humano.

Para fundamentar esses aspectos, citamos Ayres (2003-2004) quando faz reflexões sobre as práticas de saúde e o cuidado com as pessoas:

Assistimos em tempos recentes à emergência de uma série de novos depoimentos no campo da saúde pública, mundial e nacionalmente, tais como a promoção da saúde, vigilância da saúde, saúde da família, redução de vulnerabilidade, entre outros. Tais depoimentos revelam a 
vitalidade conceitual da saúde pública deste início de milênio e traz ao debate diversos convites à renovação das práticas sanitárias. Contudo, uma efetiva consolidação dessas propostas e seu mais conseqüente desenvolvimento parece-nos depender de transformações bastante radicais no nosso modo de pensar e fazer saúde, especialmente em seus pressupostos e fundamentos. Acreditamos que há uma série de aspectos filosóficos que precisam ser revisitados para que, aos avanços conceituais já alcançados, possam corresponder transformações práticas mais expressivas. (p.74)

Considerando a natureza do tema, a perspectiva como pretendo enfocá-lo e, principalmente, pelo meu "interrogar" - o que é isto, o envelhecer?- optei pela metodologia de investigação fenomenológica.

Conforme Carvalho (1987), a fenomenologia contemporânea surgiu na Alemanha, com Edmund Husserl (1859-1938). Foi ele quem iniciou esse movimento filosófico que trata da descrição dos fenômenos da consciência. A forma de acesso que o observador tem para "penetrar" nos "objetos" vividos ou "noemas" é a empatia. Husserl, em contato com o filósofo Franz Bretano, alertou para as "insuficiências das ciências humanas”, censurando que elas estavam seguindo o modelo das ciências naturais, sem discernir que seus objetos eram diferentes. Ele propõe, então, a construção de uma ciência para as experiências vividas- $a$ fenomenologia- que põe em evidência que os seres humanos não são objetos e que suas atitudes não podem ser vistas como simples reações (MARTINS, BOEMER; FERRAZ; 1990).

Corrêa (1997) reafirma a definição de Fenomenologia, conforme Husserl: "ciência dos fenômenos", sendo fenômeno compreendido como o que é imediatamente dado em si mesmo à consciência. A autora esclarece mais sobre o fenômeno como objeto de investigação fenomenológica, citando Martins; Boemer; Ferraz (1990, p. 141):

Do grego phainomenon significa discurso esclarecedor a respeito daquilo que se mostra para o sujeito interrogador. Do verbo phanesthai como mostrar-se, desvelar-se. Fenômeno é, então, tudo o que se mostra, se manifesta, se desvela ao sujeito que o interroga. 
Segundo Bicudo (2000, p. 71), “a Fenomenologia tem por meta ir-à-coisa-mesma, tal como ela se manifesta, afastando-se, em um primeiro momento, de pressupostos teóricos e de um método de investigação que, por si, conduza à verdade."

Fenomenologia tenta estudar a experiência humana tal como é vivida; assim não é apenas um método de pesquisa, mas é, também, uma filosofia e uma aproximação. (OMERY,1983)

Diferentemente do método das ciências naturais, a Fenomenologia não parte do pressuposto filosófico de que há uma verdade, mas que há verdades que são temporais e, portanto, históricas. O método fenomenológico é um método de pesquisa descritivo, indutivo e sua tarefa é investigar e descrever o fenômeno, o que inclui a experiência humana, de modo que esses fenômenos apareçam na sua mais completa amplitude e profundidade. (OMERY,1983). Para esta autora, o objetivo do método é descrever a estrutura sistemática total da experiência vivida, incluindo os significados que essas experiências têm para as pessoas que delas participaram, requerendo que o pesquisador deixe a experiência se revelar tal como existe para o sujeito, de um modo imparcial.

Capalbo (1994) define a Fenomenologia como ciência descritiva, rigorosa, concreta, que mostra e explicita o ser nele mesmo, que se preocupa com a essência do vivido, sendo uma ciência do possível, visto que ela se refere à possibilidade enquanto modo de ser da existência humana que é um poder-ser, isto é, um ser que tem o poder de projetar algo para a sua existência, para o seu futuro, de dar sentido à sua vida. A metodologia fenomenológica “....pretende dar conta à ordem do vivido tal como ele se apresenta na sua vivência" (CAPALBO, 1987, p.5).

Essa autora expõe que as vivências pertencem à ordem dos motivos e precisam ser compreendidas, necessitando que sejam previamente descritas tal como se apresentam na 
experiência vivida. Segue pontuando que a Fenomenologia faz a leitura dos fenômenos, acolhendo algo que lhe é apresentado, que se faz presença viva.

Citando Merlau-Ponty, Capalbo (1987) diz que a Fenomenologia se preocupa em mostrar como se dá a constituição do sentido pelo sujeito, como o sentido se faz pelo e para o homem no entrecruzamento de suas experiências mediatizadas pelo corpo próprio, pela coexistência com os outros homens, pela ação que empreende na práxis histórico-socialpolítica, pelos sentimentos e afetos que vivencia.

Compreendo que a fenomenologia não é apenas descritiva, pois ela vai além: é discurso compreensivo e interpretação.

Boemer (1994) lembra que, ao lançar-se na pesquisa fenomenológica, o pesquisador tem dúvidas sobre algo e essas o levam a interrogar, percorrendo uma trajetória em direção ao fenômeno por meio do sujeito que vivencia uma situação. O fenômeno surge a partir do sujeito que sabe, mediante sua vivência e seu modo de ver o mundo e mostra-se para o pesquisador, que busca captar a essência desse fenômeno. O fenômeno surge para o pesquisador enquanto algo que requer um desvelamento, tendo, no sujeito que o descreve, um parceiro neste processo de descoberta.

A Fenomenologia surge como uma forma de pesquisar e assistir em Enfermagem por compreender o homem no contexto histórico - cultural do seu próprio existir. Essas autoras mencionadas ressaltam que a abordagem fenomenológica pode contribuir quando a questão central do estudo for o sujeito como pessoa que vivencia o mundo de modo próprio - a pessoa que cuidamos, sujeito de nossas ações de cuidar.

A investigação fenomenológica trabalha sempre com o qualitativo, com o que faz sentido para o sujeito, com o fenômeno posto em suspensão, como percebido e manifesto pela linguagem; trabalha também com o que se apresenta como significativo ou relevante no contexto no qual a percepção e a manifestação ocorrem. É preciso irmos ao sujeito que 
percebe e perguntarmos o que faz sentido para ele, tendo como meta a compreensão do fenômeno investigado. O sujeito expõe aquilo que faz sentido, ou seja, ele descreve o percebido (BICUDO, 2000).

Carvalho (1987) explicita que o método fenomenológico, conforme proposto por Husserl, tem como objetivo captar a vivência do fenômeno, construindo um conhecimento deste e não sobre ele. "Um saber do "phaenomenon" refere-se, essencialmente, a uma constituição de sentido. Uma abordagem fenomenológica implica na pergunta fundamental: a que maneira de vivenciar ou intencionar o mundo corresponde o comportamento considerado?" (CARVALHO 1987, p. 16).

$\mathrm{Na}$ vertente fenomenológica heideggeriana, todo questionamento é uma procura que retira do procurado sua direção prévia. O procurado não é algo inteiramente desconhecido, embora seja, de início, algo completamente inapreensível (HEIDEGGER, 2005, parte I).

Considero o envelhecimento uma questão significativa e inerente à existência humana, merecedora de um olhar de natureza compreensiva, visando a pessoa como sujeito e não objeto, para que se possa construir um saber não sobre o sujeito, mas do sujeito. Capalbo (1987) ressalta que há sempre um pressuposto quando se começa a refletir, a pensar, ou seja, a nossa própria existência, que precisa ser explicitada, compreendida e interpretada. 


\section{Os cenários das vivências}

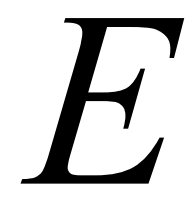

ste estudo, de natureza qualitativa, conduzido segundo a abordagem fenomenológica, tem como sujeitos as pessoas idosas, freqüentadoras de dois Centros de Convivência do Idoso - os centros "João Nogueira Vieira" e "Elias Lahdo", ambos na capital de um estado da região centro-oeste do Brasil. A opção pela fenomenologia se deu tendo em vista meu interesse em compreender a experiência vivida pelo sujeito que está envelhecendo, abordando a mesma sob a perspectiva da pessoa idosa.

Segundo Martins e cols. (1990, p.141), a fenomenologia tem a preocupação de descrever o fenômeno e não de explicá-lo, de buscar relações causais. A intenção é “....no sentido de mostrar e não em demonstrar; a descrição prevê ou supõe um rigor, pois, através de rigorosa descrição, é que se pode chegar à essência de um fenômeno.”

O Centro de Convivência do Idoso (CCI) “João Nogueira Vieira” localiza-se na região central da cidade, anexo ao Horto Florestal, com linhas de ônibus que atendem várias regiões, possibilitando fácil acesso aos participantes, os quais dispõem de atividades tais como: teatro, música, ginástica, dança, alfabetização, excursões, entre outras. Existe também convênio com uma instituição particular de ensino superior que permite a atuação de acadêmicos dos cursos da área da saúde, entre eles a Enfermagem, que desenvolvem consulta de enfermagem e educação em saúde. O horário de funcionamento é de segunda a sexta-feira, das 7 h30min. às $11 \mathrm{~h}$ e das 13 às $17 \mathrm{~h}$.

Foi fundado em maio de 1995 e tem por finalidade assegurar o atendimento das necessidades sociais da pessoa idosa, estimulando sua integração e valorização na família e na comunidade. É mantido pelo Fundo de Apoio à Comunidade - FAC, através do Projeto de Apoio à Pessoa Idosa - PAPI da Coordenadoria de Assistência Social e Atenção à 
Comunidade, da Secretaria de Assistência Social do município. Suas principais finalidades são: proporcionar ao idoso oportunidade de conviver com pessoas da mesma faixa etária, incentivando a troca de experiências, conhecimentos, formação de vínculos afetivos e momentos de cultura e lazer; incentivar a formação de grupos de idosos, visando um real entendimento do processo de envelhecimento; fomentar a participação e a integração do idoso em organizações representativas; proporcionar a participação em programa de alfabetização e escolarização, com metodologia e horários adequados às suas condições; orientar sobre programas e projetos voltados para assistência ao idoso, com base no Estatuto do Idoso - Lei 10471, de 01 de outubro de 2003, e Política Nacional do Idoso (Lei 8842/94, regulamentada em 1996); incentivar o convívio de idosos com gerações mais novas; assegurar ao idoso alimentação complementar (lanche) durante a realização de atividades; prover espaço físico e recursos humanos adequados para atendimento ao idoso.

O ingresso das pessoas é de caráter voluntário, a partir dos 60 anos, desde que tenham rendimento mensal de até dois salários mínimos (para assegurar que a população atendida seja aquela que não dispõe de outros recursos para as atividades oferecidas no local), e preencham cadastro na instituição. Tem capacidade para atender 350 idosos, sendo que estão cadastrados 433, na faixa etária de 65 a 90 anos (dados de outubro de 2005). Tem como recursos humanos duas assistentes sociais, três professores de Educação Física, três professores de nível superior (pedagogas), três instrutores (coral/ dança/trabalhos manuais) e uma coordenadora, que também é assistente social.

No regimento do CCI consta um capítulo sobre os direitos e deveres das pessoas que freqüentam o local, dentre os quais destaco: não fumar ou consumir bebidas de origem alcoólica e outras substâncias psico-ativas nas instalações do CCI; usar roupas adequadas conforme necessidade da atividade; art. $12^{\circ}$ - não poderá ser cobrada dos idosos qualquer tipo de taxa, em nome do Centro de Convivência. 
O outro cenário é o Centro de Convivência "Elias Lahdo", que se localiza na região norte da cidade, no bairro Monte Castelo, tendo a mesma vinculação institucional que o CCI “João Vieira Nogueira”. O CCI do Monte Castelo atende cerca de 150 idosos e conta com sala de alfabetização, sala de reuniões, área para jogos de mesa, sala para trabalhos manuais, sala de administração, cozinha, sanitários, varanda e área de serviço.

Tem por finalidades a integração dos idosos da região à comunidade; estudo e divulgação do processo de envelheciment; resgate da cidadania da pessoa idosa; integração de gerações; alfabetização/escolarização, jogos/recreação; coral; psicodrama; dança; teatro e encontros educativos, além do atendimento pelos acadêmicos de um curso de Fisioterapia e de um curso de Educação Física, de uma instituição particular de ensino superior. O horário de funcionamento é de segunda a sexta feira, das 07h30min às $11 \mathrm{~h}$ e das 13 às $17 \mathrm{~h}$.

Selecionei esses locais pela possibilidade de encontrar pessoas ativas, na faixa etária acima dos 60 anos, consideradas como idosas pelo Estatuto do Idoso (Lei 10471/03; art. $1^{\circ}$ ) e que contemplam a proposta para esta investigação. Basicamente, a diferença entre os dois centros está no perfil da clientela que freqüenta o local, sendo que o CCI "João Vieira Nogueira", por sua localização mais central, tem um número maior e mais diversificado de participantes, vindo de várias regiões da cidade. No período da manhã, ocorre o maior afluxo de pessoas, aumentando a possibilidade de realizar as entrevistas. Já no CCI "Elias Lahdo", a maioria dos freqüentadores é das proximidades do bairro e participam das atividades físicas e de lazer. O acesso dos idosos até os locais é feito de ônibus, a pé ou transportado por alguém da família ou amigo.

Acredito que a diversificação de pessoas, como sujeitos deste estudo, contribui para uma visão em perspectivas do fenômeno a ser pesquisado.

Após autorização da Secretaria Municipal de Assistência Social e dos coordenadores dos Centros de Convivência, passei a freqüentar, semanalmente, os dois locais escolhidos. 
Estive presente em vários momentos, de agosto de 2005 a junho de 2006, quando procurei habitar o mundo dessas instituições, ou seja, comecei a conviver com as pessoas e participar de suas vidas.

Segundo Simões e Souza (1997), a visita prévia ao local, antes da coleta de dados propriamente dita, permite que o pesquisador apresente-se ao grupo, de forma pessoal e profissional, dando-se a conhecer, esclarecendo a proposta do estudo e aprimorando a abordagem aos sujeitos.

Aos poucos fui sendo inserida no cotidiano das atividades dos CCIs e, ao ser reconhecida como enfermeira, era consultada sobre alguns aspectos de saúde e doença e solicitada a fornecer informações. Alguns freqüentadores eram mais receptivos, alegres, extrovertidos e, com descontração, convidavam-me a inserir-me naquele mundo. Estive presente nas comemorações dos aniversariantes do trimestre, na festa de fim de ano, nas palestras educativas realizadas por outros profissionais, nos ensaios das coreografias, nas apresentações do grupo de dança, enfim em muitas das atividades por eles desenvolvidas, não apenas como observadora, mas inserida no viver daqueles momentos. 


\section{Na presença do outro: as entrevistas}

Após a aprovação do projeto pelo Comitê de Ética da Escola de Enfermagem de Ribeirão Preto, iniciei a busca dos elementos para análise, que se deu no período de março a junho de 2006, com visitas semanais aos locais, sendo no CCI "João Nogueira Vieira" às quintas - feiras pela manhã e no CCI "Elias Lahdo" às quartas - feiras no período da tarde. Reapresentei, para cada grupo, o motivo da minha presença e como gostaria de contar com a colaboração deles para compreender este viver: o envelhecer.

A princípio não tinha um número definido de entrevistas a realizar, pois, em fenomenologia, as informações são obtidas até o momento em que o fenômeno possa se mostrar ao pesquisador, pelos depoimentos dos sujeitos, ou seja, até que haja convergências/divergências. É a busca pelo invariante, segundo Husserl, que permite chegar à essência de um fenômeno.

Agendei os encontros com os sujeitos, dependendo da disponibilidade de cada um. Realizei as entrevistas, conforme proposto, nas dependências dos CCI, em sala reservada e individualmente. No momento da entrevista, informava com mais detalhes a proposta da pesquisa e, se concordassem em participar, assinavam o Termo de Consentimento Livre e Esclarecido (Apêndice A), e ficavam de posse das orientações por escrito. Esse cuidado pôde criar um clima de empatia e confiança entre as pessoas envolvidas no encontro, possibilitando um "ouvir" compreensivo. Solicitei a permissão para gravar os depoimentos e a maioria concordou de imediato; para outros, precisei explicar melhor o motivo da gravação para depois iniciar a entrevista. Somente uma não foi gravada por problemas técnicos no equipamento. 
A princípio, as entrevistas, conduzidas segundo a abordagem fenomenológica, teriam como eixo a seguinte questão norteadora: "Conte para mim como está sendo para o Sr.(a) vivenciar este momento, ser sujeito neste processo de envelhecer?".

No entanto, após algumas tentativas, percebi que tais termos não estavam sendo compreendidos pelos sujeitos. Então, precisei reformular a questão para alcançar a proposta do estudo. Perguntava: "Como é chegar a esta idade? Viver até tantos anos?" Procurei não utilizar as terminologias mais comuns empregadas para designar as pessoas desta faixa etária, tais como terceira idade, melhor idade, velhice, mas usei envelhecer e envelhecimento. Utilizei também os termos idoso e pessoa idosa como alternativa para velho, velha, considerando que algumas pessoas poderiam entendê-los como depreciativos.

Para Carvalho (1987), a questão formulada adequadamente é possibilidade de mergulho no Ser, é aquela que possibilita um "se fazer ver" do cliente. "É reabrindo o tempo no presente da entrevista que se pode perceber a verdade do passado e antever a verdade de um futuro" (CARVALHO, 1987, p.54).

Essa autora esclarece que a entrevista é um método de acesso às pessoas e, na perspectiva fenomenológica, busca a compreensão e não a explicação. A verdade da situação é mostrada na entrevista, na totalidade do que diz o cliente e em todos os movimentos que efetua, captando-se a sua forma de "vivenciar" o mundo.

A entrevista não teve, a princípio, um tempo limite e estava relacionada à disposição das pessoas para descreverem sua vivência. Carvalho (1987, p. 29) alerta que "ver e observar de uma perspectiva fenomenológica é ver e observar a partir do espaço e do tempo do cliente”, captando sua subjetividade. Nesta perspectiva, a entrevista flui de maneira compreensiva, isenta de análise conceitual pré-definida, de modo que possibilite um saber "do" cliente e não "sobre" o cliente. 
O entrevistado faz a descrição da sua vivência, um relato de alguém que sabe alguma coisa para alguém que não sabe, sem dar importância a regras, normas ou estilo literário (MARTINS; BOEMER; FERRAZ, 1990). A descrição será tanto melhor quanto mais permitir "ver" o que está sendo descrito. O momento da entrevista não pode ser visualizado como um procedimento mecânico, mas como um encontro social, uma relação pesquisador-pesquisado caracterizado pela empatia, intuição e imaginação.

Faço aqui um parêntesis para pontuar algumas idéias básicas sobre imaginação, segundo Joel Martins (1984). Para este autor, “o ser humano pode abstrair e objetivar as coisas no seu redor assim como no seu mundo. Esta é a natureza ontológica do ser humano, este ser que pode pensar, falar e simbolizar" (p. 132). Decorre destas possibilidades que o ser humano pode compreender-se a si mesmo e aos outros e, para tanto, representa, simboliza, pensa e imagina.

A imaginação é um ato mágico, um encantamento destinado a fazer surgir o objeto pensado, a coisa desejada, de forma que possa ser apropriada por quem pensa. Sentimentos, conhecimento ou vontades que uma pessoa possa ter dependem, em último recurso, da imaginação que ela tenha daquelas coisas sobre as quais pode pensar, falar, entender. (p.132). Imaginação é reflexão, é uma possibilidade de refletir sobre o eu de si próprio e o eu dos outros.

Através da imaginação estou assumindo a possibilidade e a realidade de se ter uma percepção de outra pessoa, ainda que seja através do ver dessa pessoa, do seu olhar as coisas e o mundo. Tal percepção do outro pode ser considerada fenomenologicamente possível( MARTINS, 1984, p.135)

O autor ressalta que a fenomenologia não pretende fazer uma percepção infalível do eu do outro, mas que é possível chegar ao conhecimento do outro pela analogia e empatia. Entretanto, o acesso direto ao seu mundo nem sempre acontece, pois pode-se ver seus olhos, mas não se pode ver o que é que a outra pessoa vê através deles. Então, a imaginação 
disciplinada, isto é, aquela que não inventa, não anda ao acaso, não devaneia, pode ser uma aproximação para participar do mundo dos outros.

É preciso que eu me imagine ocupando o lugar real do outro e veja, a partir de lá, o mundo como ele se apresenta nesta nova perspectiva. Martins chama isto de autotransposição, quer dizer que preciso sair de mim mesmo e adotar, imaginativamente, o esquema da mente da outra pessoa. Em outras palavras, preciso projetar o mundo como ele apareceria através dos olhos do outro, mesmo quando eu não posso usar os olhos dele, mas apenas os meus (MARTINS, 1984).

Fundamentada nesses princípios, realizei dezessete entrevistas, sendo nove no CCI “Elias Lahdo" e oito no CCI "João Nogueira Vieira". No primeiro, foram dois homens e sete mulheres, com idades variando de 61 a 78 anos; no segundo, foram sete mulheres e um homem, com idades variando de 66 a 83 anos. A intenção em descrever os aspectos numéricos em relação aos sujeitos é apenas mostrar quem são eles nos cenários da pesquisa. Por esta descrição vislumbramos a realidade geral dos centros de convivência visitados, onde a maior parte da clientela é formada por mulheres, com idades variadas. Encontrei também pessoas mais idosas, com noventa, noventa e três anos.

A maioria das mulheres é viúva, algumas de longa data e que chegaram a esses locais de atividades levadas por uma amiga. Mesmo as casadas os freqüentam sozinhas, isto é, sem os companheiros. Os homens entrevistados também iam desacompanhados. Encontrei poucos casais realizando juntos as atividades.

O grupo é heterogêneo, com alguns participantes apresentando determinado problema de saúde, no entanto sem comprometimento da autonomia e independência, uma vez que são capazes de exercer as atividades propostas e se locomover até os CCIs.

Após o término de cada entrevista, retrocedia a fita para que a pessoa pudesse ouvir a gravação, complementando ou modificando o que foi dito. Tal procedimento justifica-se 
também nas orientações de Carvalho (1987) quando pontua que a entrevista fenomenológica busca uma linguagem que seja "fala originária", "fala" esta que possibilite a mediação com o outro e a comunicação com o mundo, indo além da soma de pensamentos e idéias, na qual a atitude fundamental é a de "escuta". Além disso, era um modo de garantir aos participantes que utilizaria somente os depoimentos gravados com suas permissões.

Os elementos para análise foram surgindo das descrições obtidas nas entrevistas, com os depoimentos transcritos na íntegra, procedendo-se à leitura preliminar e reportando-me ao momento do encontro, com intenção de tornar cada relato familiar, conforme exposto por Lopes e Souza (1997). Considerei aqui os aspectos da comunicação não verbal, que são constituintes do fenômeno estudado, tais como postura, gestos, tom de voz, expressão facial e silêncio, pois, conforme Carvalho (1987, p. 38), “... o cliente tece seu discurso com todos os gestos necessários, acentos e tonalidades, silêncios e reticências.” Ele vive sua história e coloca seu passado e seu futuro no presente. Portanto, compreender o pensamento do cliente é penetrar o seu mundo, sua presença e sua vida. E, para tanto, há que haver uma comunhão com quem fala, um ouvir olhando para o cliente, envolvendo-se com ele.

Essa forma de olhar o outro com atenção, para além de nós mesmos, permite ampliar o horizonte de “....observação do mundo e das coisas para, então, compreender a realidade que nos cerca não como algo dado e estanque, mas que está em processo de constante descoberta" (BOARETTO, 2005, p. 50).

Procurando personalizar os depoimentos e interligar seus conteúdos às pessoas entrevistadas, mas mantendo o seu anonimato, optei por identificá-las segundo os códigos: para os homens, em menor número, utilizei nomes de diferentes pássaros. Para as mulheres, borboleta ou mariposa, acrescentando o número da entrevista e a idade de cada um ao lado. 


\section{Os depoimentos das pessoas idosas}

"Diante das cãs te levantarás, e honrarás a presença do ancião..." 


\section{Entrevista 01: BORBOLETA 1 (72 anos)}

-Boa tarde, é enfermeira Maria da Graça. Olha minha vida no momento "tá" sendo pra mim "tá" sendo boa. Porque minha velhice "tá" maravilhosa eu "tô" com saúde, tenho meu esposo que não me impede de eu freqüentar nada que eu queria, ele não impede. Ele não vem, mas ele não fica, ele não me impede de eu vir. Então eu me sinto feliz na minha velhice, eu tenho saúde $^{1}$. Graças a Deus, minha pressão é boa, não tenho diabetes, não tenho outras doenças nenhuma. Graças a Deus, minha vida "tá" sendo maravilhosa!

-Prá mim significa... eu dô Graças a Deus, porque muitos, que nem meu pai e minha mãe foram novo, né, e eu, com 72 anos, Graças a Deus, "tô" feliz de ter chegado até agora.

-É eu passei por muitas tristezas porque quando eu vim de São Paulo pra cá, não sou daqui né só meu marido é matogrossense e eu perdi um filho; essa foi a minha tristeza na minha vida aqui, né. Mas Graças a Deus, se Deus me deu e tirou é porque tinha que ser dele, né, novinho. Então, eu sigo, consigo passar por tudo isso né. Graças a Deus "to" feliz, né, tenho minha filha, dois netos, né, "tô" muito bem, né, Graças a Deus, meu esposo é maravilhoso, né, e eu vou vivendo assim, Graças a Deus.

-Ah! Eu sinto porque a gente, muitas coisas que eu fazia quando era nova agora não posso fazer, né, a gente vai perdendo as forças, não dá conta de fazer, né. Então...mas a gente tem que agradecer a Deus, né, por estar vivo.

-Olha minha vida foi assim né, quando eu vim de São Paulo pra cá, fui morar na fazenda do meu sogro que fica perto de Bela Vista, entre Bela Vista e Jardim e lá eu tinha meus, meus dois filhos, né, que é a menina e o menino, ela mais velha, ele é o mais novo, e daí ele pegou aquela doença hepatite que antigamente a gente não falava hepatite, falava "tirícia", e todo mundo, ninguém sabia curar a não ser com chazinho caseiro. Aí nós começamos a tratar dele em casa, com cházinho caseiro, era difícil, era fazenda, era mato, não tinha estrada, não tinha ônibus ali, nóis não tinha carro, era só a cavalo. Então, aí ele foi ficando bem doentinho, doentinho, quando ele ficou bem ruim mesmo, a gente levou pra Jardim, em Jardim também os médicos não sabia tratar naquela época. Quando ele ficou bem (enfatiza) mal memo que eu internei ele lá em Jardim daí o médico falou que não tinha mais recurso porque o sangue dele tinha virado água, né, sem a gente saber tratar, então aí eu perdi ele e fiquei só com a menina. E essa foi a minha história que tenho prá contar aqui de Mato Grosso. 


\section{Entrevista 02: COLIBRI ( \pm 78 anos)}

-Olha, "duns" tempo pra cá, depois que eu larguei da mulher, já (pausa) eu tenho perecido, "num" foi muito bom mas sempre vivo muito também satisfeito, né, por causa dos amigos que a gente tem (pausa) e sempre, nun..nun...nunca fiquei doente quase. Agora de uns tempos pra cá me deu começo de pneumonia, né, mas, eu ando até muito bem, onde moro, pago aluguel, né, lá o pessoal é muito bom prá mim, DEMAIS, tenho minha família que mora perto, meus filhos sempre ta lá em casa, né, "tô" sentindo muito bem. Moro sozinho, mas o pessoal meu tá tudo junto comigo, né. Então, eu mesmo é que faço tudo em casa, né, mas meus filhos sempre estão em casa, tudo comigo lá né, de vez em quando tá lá em casa, né. Tem a grande diversão de vir brincar aqui (CCI), né jogar, né e...de vez em quando eu vou na, na....Agora tá mais ou menos com uns dois anos que eu não vou na Bolívia. Sempre meu filho vai; quando ele vai levar os alunos, ele leva, vai pra lá, ele fala -“Vamos pra Bolívia, pai?”. Então vamos. Vô junto, né; lá eu fico lá um dia, no outro dia a gente vorta. "Tô" sentido uma vida boa, né. Ando bem sadio, né, andei meio doentezinho, mas agora "tô" bem sadio, A dotôra olha bem por mim, né. Graças a Deus "tô" muito bem. Me sinto bem, né. Num "tô" sentido mais indisposto, só sinto alegria e boa vida pra todos, né. 


\section{Entrevista 03: JOÃO-DE-BARRO (71 anos)}

-Olha eu fui uma, eu fui um (pausa) uma pessoa muito (enfatiza) muito maltratada. Sobre a minha criação, que eu não fui criado com meus pais mesmo, quando eu tinha três anos de idade, minha mãe faleceu e aí, meu pai pegou e deu eu pra outra pessoa criar. Ge (gagueja) geralmente é meu pai porque de registro, né, mais é, eu fui MUITO maltratado, muito mesmo, inclusive eu achei que a minha vida não ia "arcançar" 40 anos, Graças a Deus "tô" com 72 anos, 71 e "tô" aqui. Então, sobre essa pergunta de envelhecimento, ela é boa (pausa), boa, a gente sabendo tratar os ôtro ela é boa, porque a gente tem que saber certa altura, tem que saber respeitar pra ser respeitado, porque tem muita gente que fala "-ah é...essa criança aqui não precisa ser respeitada", ah! Não! Diferente, tem que ser respeitada, a criança, adolescente, tudo tem que ser respeitado porque eu respeito, e Graças a Deus, tenho saído bem, porque (pausa) geralmente as pessoas me respeitam e meus filhos, tudo, Graças a Deus nunca tive "probrema" com filho, todos me respeita, qué dize depende porque (gagueja) é a criação que eu dei pra eles; porque tem muita gente que fala: - é meu filho, não precisa respeitar pra quê? Não é pelo contrário (enfatiza); eu trato meus filhos, homem pra homem, né, negócio é ali (enfático), se eu faço negócio com eles, eu compro, pago, eles mesma coisa, então nós somos assim, tanto filhos como as filhas. E... e Graças a Deus eu tenho me sentido bem com isso, é...trato bem os "ôtro", (pausa), mas muito bem memo, aquilo pra mim é que nem, é é..., um prazer, uma satisfação que eu tenho em saber tratar os ôtro, e gosto de tratar, de ser tratado, então é uma coisa que...que sobre o meu envelhecimento, eu sou muito feliz, muito Graças a Deus, porque o quê eu tinha de passar, eu passei, que é problema de saúde sério, tive várias "veiz", fui ofendido de cobra por 3 “veiz", tive na "bera” da sepultura, mas Graças a Deus, eu sai dessa, então eu sou uma pessoa feliz, vivo muito bem com a minha família, não tenho, "probrema" nenhum com meus vizinho, com todo mundo, eu combino com todo mundo porque é gostoso, então eu não posso adiantar muita coisa agora, porque a memória foge um pouco, mas eu "tô" a disposição pra "quarqué" hora que eu for chamado, o que eu, assim (vacila), idear uma coisa melhor né, pra gente gravar aí pra você, mas se ficou satisfeito é isso aí.

(Minha mãe morreu) por causa de mim, porque ela assustou muito quando...quando recebeu a notícia que a cobra tinha me pegado...

Entrevistador: Ah! Que o senhor era pequeno....

- É eu tinha 3 anos; só que eu tava brincando com a minha irmandade, deu um...uma tempestade meia forte e caiu uma ramada de maracujá em cima da bica, e nóis subia aí em cima, eu lembro como se fosse hoje, 3 anos de idade, aí um dos irmãos me falou -“óia”, deixa 
eu subir, "primero" aí do lado memo, que você ta demorando muito (eu era muito pequeno!) e eu enfiei o pé por baixo da viga e a cobra tava lá e pegou. Então, na hora já escureceu minha vista, já não enxerguei mais nada e falei com uma das irmãs:

- Olha um bicho me pegou aqui, num "tô" enxergando nada, eu "tô" cego. Aí me "levaro" de soco lá e contou pra minha mãe, que tava na cama, aí ela recaiu e não teve cura, né, faleceu né, por causa desse problema, então eu fiquei muito chateado com a minha família, muito mesmo (enfático), porque quando eles deram eu tava ofendido dessa cobra, e naquela época não tinha...., era só benzeção, não tinha médico, não tinha nada. Aí que... que acontece, meu pai (procura as palavras) além de tudo era vida torta, e foi nesse meio tempo, ele foi preso, eu fiquei sozinho lá na casa, em cima de uma cama, meu pé "bichou", daquele bicho de vareja "memo", bichou ficou bem ruim, com 4 dias que ele tava preso é que ele lembrô que existia eu (emociona-se), ai comunicou com o delegado que tinha esse menino lá, que tava assim, assim, aí "fôro" lá, comprovaram, né. Chegô lá, que que acontece, ele foi lá no manguero, pegou um vidro de creolina e curou com creolina "memo". O meu pai morava perto e nem pra “comparecê" lá pra me ver, depois que o velho foi..., a polícia chegou lá, realmente o menino “tá" morrendo, lá, "tá” com o pé todo bichado; aí que meu pai foi lá, pra cuidar, o "ôtro" pai tava cuidando, mas é...foi uma vidinha meio penosa pra mim. Passei um vida, uma vida de doido. Então, tudo isso a gente...revolta com a família, porque família, família são os irmãos. Meu pai logo veio a falecer também ficou só a irmandade. Nóis num "cumbina" muito bem; a gente vai na casa um do outro, é é ...assim por uma causalidade, a gente encontra muito quando fica um doente, a gente vai fazer uma visita, mas não passou daí, passou, não tem mais...então é ... Graças a Deus, eu sai dessa, mais "sô" revoltado. 


\section{Entrevista 04: MARIPOSA 4 (61 anos)}

- Ah! Assim (pausa) a partir dos 40 anos, já começou (pausa) dar mostras do envelhecimento, até então não tinha sentido nada não, mas daí já começou (pausa, parece procurar palavras) a eu ter problemas mais de saúde também, né, aliás antes disso eu tive vários problemas de saúde, é....(parece lembra-se) extração de um rim, por exemplo, é...várias cirurgias, tive uma gravidez tubária que acabou me dando uma hemorragia interna e isso foi bem antes, né. Mas até então eu fui superando tudo sem problema, né. Aí a partir dos 40 é que o negócio começou pegar mesmo, por que aí começou a parecer a pressão, foi alterando, né, como a chegada da menopausa também é... a diabetes já chegou junto, e aí, daí, pra cá, então eu tô direto só com remédio (pausa) assim de uso contínuo, tanto pra pressão quanto prá diabetes, né, é, e, tive assim conseqüência, já, há pouco tempo, por exemplo, conseqüência de um tratamento pru, prá infecção urinária, eu fiquei sem equilíbrio, fiquei..., me atacou parece que uma, tipo de uma labirintite, foi tão forte que eu não conseguia nem dentro de casa me locomover sozinha, eu caía mesmo, num tinha era...assim, desequilibrava mesmo, as pernas num, num aceitava o comando da cabeça parece, aí, com um bom tempo, mais uns seis meses de tratamento e....demorou muito também pra médico (pausa) achar, encontrar o quê me levou aquele estado, aí, acabou descobrindo que foi um medicamento que eu tomei muito forte, aí comecei a fazer o tratamento certo, né, e aí eu já comecei a melhorar, quando eu comecei a melhorar eu já vim pra cá também (CCI) isso foi o ano passado. Aí depois disso foi só melhorando, Graças a Deus, hoje eu venho, volto sozinha, de a pé, tomo ônibus quando tô cansada e ou atrasada quando "tô" atrasada eu tomo ônibus, prá vim só volto (pausa) aí, beleza, não tem mais nenhum problema não, de saúde, não.

-Olha, depende muito da cabeça de cada um viu! Porque eu não me sinto...envelhecida, minha cabeça é livre de preconceitos de envelhecimento ou de tal, eu não acho que eu não posso usar uma roupa porque estou velha, não acho que eu não posso usar um corte de cabelo porque eu "tô" ficando velha ou ir dançar em qualquer lugar porque eu "tô"...então participar, né, de atividades porque é coisa de mocinha, não me sinto assim, então não tenho nada assim que possa ser (pausa) ter uma importância maior.Eu topo tudo qualquer hora é hora.

Entrevistador: - O quê incomodou mais a senhora foi a questão da saúde? Tirou isso.....

- Tirou isso....sem problema, sim problemas emocional também, né, a perda do meu marido, a doença dele que foi muito triste, muito, assim, muito desgastante também, né, me deixou assim muito abalada mesmo porque dois anos eu cuidei dele assim, sem sair de perto prá nada, então ele, ele não queria que eu fosse sair nem prá ir na cozinha, nem pra ir no banheiro, ficava grudado na minha mão, então foi um período assim...eu não vendo nenhuma melhora, 
ele cada vez pior, cada vez pior, né, com todo o esforço que fazia, então foi assim uma fase muito ruim. Aí depois disso, já fazem 4, já vai fazer 5 anos agora que ele faleceu, aí depois duns 3 anos do falecimento eu comecei já me....aquilo ali já foi passando, já (pausa e emoção) Deus é bom, né, ajuda, o tempo também é bom, vai curando as feridas e aí é só, não tenho mais nada. 


\section{Entrevista 05: MARIPOSA 5 (73 anos)}

- Tá, agora eu vô começá, tudo de novo, agora que eu lembrei, que eu sou nordestina, né. Eu me casei aos 24 anos, vim para o estado de São Paulo, fiquei dois anos lá no estado de São Paulo; meu esposo, tinha problema de coração, de Chagas, problema de Chagas (enfatiza) mas nós conseguimos viver 35 anos de casado, mesmo com a.... ele sofreu muita malária aqui, né, muita coisa , então a gente viveu 35 anos de casado, temos 10 filhos, tem...(procura se lembrar), 22 netos, agora já "tá" iniciando os bisnetos, já tenho um bisnetinho, né, e até o fim do ano chega mais um. E eu trabalhei, morei na roça muito tempo, uns (pausa para recordar) 13 anos depois de casada ainda, antes eu já morava na roça, toda vida sô caipira mesmo (risada), eu sô.... eu sô... caipira mesmo, né,! Então a gente veio pra cidade em 71 eu cheguei em Campo Grande, aqui de morada e tô até hoje. Graças a Deus, consegui trabalhar no Estado, trabalhei por 20 anos, aposentei, mas eu continuo é trabalhando, eu num...me acho velha, eu acho que eu sô jovem, num sinto a velhice, nóis vivemos todos em paz, todos os filhos reúnem em casa, são maravilhosos, tá todos....a gente tem paz com todos, né, são 4 homens e 6 mulher, tem 2 solteiro; a caçula e o caçula; o caçula mora comigo, a moça mora pra fora, num sei pra onde, que mora com outra mulher, né, num sei...mora prá lá (gesticula para mostrar) prá banda do Santo Amaro (percebe-se a reprovação, na entonação da voz, pela situação da filha). E eu achei maravilhoso, eu trabalho, eu faço as coisas de casa, eu ainda lavo, passo pra fora, né, prá algumas pessoas amigas que procura, eu continuo trabalhando. Eu não sinto canseira, vou prá igreja, toda primeira semana do mês nós temos oração toda noite, eu consigo ir quase todas as noites e num tenho problema, é muito bom ficar velho na minha posição, alegre, contente do jeito que eu sô, eu não...não acho diferença ainda, num vi ainda... num "tô" diferente do que eu era mais jovem, só a gente é muito pesada porque agora eu sô mais gorda, né, sô mais pesada do quê antes, antes eu era MUIIITO rebelde, subia nos pé de côco, tirava côco com a mãe (risadas) e nóis trabalhava, brincava muito, era muito bom , viu! Quem sabe ainda vou lembrá de mais brincadeira (risada). Tem, tem a minha filha também é "enfermeira", ela trabalha com...., na CASSEMS (órgão estadual de assistência à saúde dos servidores), é, é... auxiliar de médico, dos médicos, né. É uma pessoa maravilhosa! A outra filha... tem uma que é em Ji-Paraná, gosta muito de me ajuda, ela mora...., é a que mora fora do Estado, né, só ela, aí o resto tudo tão aqui, Graças a Deus tudo em paz, tudo....Aquela de Ji-Paraná tem 2 filhos, a outra tem 2 filhos, tem outra....(tenta se lembrar) que tem 2 filhas, aí tem a Maria...3, 2 homens e 1 mulher, aí o rapaz, o rapaz mais velho tem 4 mulher, tudo mulher, esse já tem 2 filha casada e tem a outra, tem aqui na Estrela do Sul também tem 2 casais, tem (pausa para recordar) 1 filho casado, e os outros ainda tão em casa. Essa é a mais 
assim....porque tem problema... mental; ela de vez em quando ataca, fica fora....assim do limite, e os demais é tudo em paz. Sô amiga de todo mundo, gosto de ajudar, gosto de....de trabalhar, o quê eu posso fazer, eu faço; nós viemos aqui (CCI "Elias Lahdo") fizemos o curso de... de doces e salgados, foi muito bom, viu, foi maravilhoso! E eu participo aqui (CCI “ Elias Lahdo") eu fiquei participando um tempo quando os outros netos eram pequeno, aí ele vinha comigo, mas aí a minha nora começou a trabalhar lá na feira, e eu comecei....aí fícava com as crianças dela, num pude vir mais Aí o ano passado, próximo ao dia das mães, eu vim, aí tô até agora (risos); próximo ao dia das mães nóis viemo, na festa junina eu já tava aqui, aí nóis continua prá frente; trabalho, venho (enfatiza), eu faço ponto cruz e desejo aprender mais coisa ainda, e quarqué coisa que vão me ensinando, vô aprendendo, viu! E agora....agora descansa um pouco por que se eu lembrar de mais....(risos) já subi nós pé de côco (risada). 


\section{Entrevista 06: BORBOLETA 6 (65 anos)}

- Prá mim tá sendo bom, já tive muitos tropeços na vida, porque fiquei viúva com...faz dezoito anos que eu sou viúva, fiquei com os meus filhos todos pequenos, porquê já casei com a idade avançada, casei com 35 anos, então prá mim assim foi um choque muito GRAANDE quando fiquei, me vi viúva e com 4 filhos, todos pequenos prá cuidar, né, mas, Graças a Deus, não posso reclamar não. Já tenho essa filha que é enfermeira, tenho outra filha que está fazendo jornalismo, né, as duas já tão casada (pausa). Tenho outro filho que é vendedor e outro filho que tá fazendo agora serviço social. E prá mim tá sendo bom, num..., num tenho o quê RECLAMAR da vida, a vida tá sendo muito boa prá mim, né, porque eu...fui criada pelos meus tios, mas quando eu tinha 22 anos ele me tocou de casa (emoção), né, então eu saí apenas com um saco de roupa, na mão, sem saber pra onde que eu ia, e eu trabalhava né, e hoje eu tenho casa, eu tenho meus filhos, tenho carro, é do meu filho, mas tá no meu nome, né, e tenho uns bons filhos, que trabalha que cuida de mim, que...tenho genros ótimos que também que...que cuida muito também de mim, então, prá mim tá sendo MUITO bom, melhor do que eu esperava, eu tinha muito medo de ficá velha (pausa), assim doente, sem ter alguém prá cuida, né, porque isso é muito difícil, mas Graças a Deus, eu acho que eu não vô tê esse problema. Pra mim tá sendo ótimo, né. Tô... tô bem melhor agora do quê quando eu era mais nova, sabe! Porque agora pelo menos eu já sinto realizada já..., os filhos tão bem, né, tive muito problema com meu filho caçula, porque eu já tive ele com 43 anos, com 16 anos pra 17 ele teve linfoma de Hodking AGORA esse ano que ele tá bem! Fui prá São Paulo, fiquei com ele lá 5 meses e 17 dias prá ele fazer o transplante; fez, a doença voltou, aí, meu filho mais velho...., porque ele ia fazer....aí chegou dá outra medula pra ele, né, mas aí chegou lá os médicos acharam que não deveria fazer, porque na primeira ele passou muito mal, ele entrou em coma (pausa com emoção) e...aí viemos embora, chegamos aqui...lá ele fez todos exames, os médicos não acharam nada, aí chegô aqui pediu uma....um outro exame, fez, e de lá pra cá, Graças a Deus, só tem dado certo, todos os exames que ele tem feito, acompanhamento, ta tudo muito bem, então eu só tenho a agradecer a Deus e a todas as pessoas que me ajudaram. "Tá” Bom? 


\section{Entrevista 07: MARIPOSA 7 (61 anos)}

- Pra mim o que....a única coisa que muda que gente tem as veiz um certo problema de esquecimento, né, "iguai" eu "memo" já tenho esse "probrema" de esquecimento, ás veiz a pessoa fala um coisa assim pra mim, assim daí um poquinho já num..num lembro mais...mais é assim, questão assim de convivência assim com as pessoas pra mim é normal eu gosto de participar, assim, "passiar", de conversar com as pessoas, eu não gosto é de ficar em casa parada muito tempo, ficar sentada eu não gosto (risos)...eu gosto de conversar com as pessoas assim, participar assim das coisas assim, né, assim que tem, né, daqui do centro de convivência, da igreja, associação também eu participo lá na associação, é a única coisa assim que eu...que eu acho assim que mudou assim as "veiz" é uma "dificulidade" pra mim é "probrema" de esquecimento, que eu esqueço muito...demais, muito fácil, eu esqueço muito fácil, por exemplo as "veiz" você fala seu nome assim pra mim daí um pouquinho eu já não "tô" lembrada, aí meu Deus como que ela falou o nome dela , como é que é, que eu não "tô" lembrada mais, é a única coisa, mais assim Graças a Deus sinto bem...eu me sinto bem...num sei, a gente sabe que num...muda mesmo, né, alguma coisa, mais eu me sinto bem Graças a Deus, é a única coisa "memo" que eu acho que mudou um pouco na minha vida, é isso, "probrema" de esquecimento, que eu esqueço. 


\section{Entrevista 08: BORBOLETA 8 (73 anos)}

- Você quer saber como que eu cheguei aos 73 anos: é o seguinte, é que eu sou uma..uma .mulher assim meia descansada; eu não esquento a cabeça com certas coisas, "tá", eu criei...criei 4 filhos: duas tão vivas, a mais velha faleceu, já faz mais de... quase 30 anos, "probrema" de coração, né, então fiquei com 3 meninas...3 meninas e adotei 2 guri gêmeo pra criá, eles já tão com 30 e...e eu acho que eles já vão fazer 35 anos já hoje, com... com...em 72 por aí, eu separei, eu divorciei do meu marido, não por minha vontade, vontade dele, que ele era muito, muito, muito, você sabe né, mulherengo. Chegou um dia que ele falou que não dava mais pra viver junto, porque ele tava vivendo comigo na mentira, porque ele só mentia, mentia, mentia, mas a gente não tinha briga. Eu não brigava, eu não xingava. Ele chegava tarde, e eu não falava nada, mentia que ia viajar e não ia, ia pra casa da amante também e como eu não falava nada, ali sempre ao lado dos meus filhos. E assim eu criei eles. Os dois guri tão por aí, um mora em Natal; o outro tá aqui. E as duas meninas... estudaram por minha conta. Fizeram... as duas tem faculdade, a mais velha tem quatro faculdades, a mais nova tá na segunda faculdade, tá fazendo direito, mas já tem uns quarenta e poucos anos, que já são casadas; tão cum...a mais nova tem uma filha de onze anos, a mais velha tem uma filha... de sete ...de sete anos, um filho. E tão... tão vivendo, eu tô vivendo, eu trabalhei muito, trabalhei pra chega aonde eu tô, não deixei faltar NADA pro meus filhos, não passaram fome, né, porque o pai foi embora e falou vocês se viram, não quero mais, eu tenho outra,eu vou embora, tudo bem, não teve briga, não teve nada, eu peguei a roupa dele joguei fora e ele foi embora, e assim eu criei meus filhos... fui trabalhar, trabalhei quase quinze anos no hospital, no hospital do exército, cozinhando, sendo cozinheira, cozinhei pra pagar colégio, que ela estudava no colégio caro, colégio MACE a mais velha e ali ela se fez pedagogia. Se formou pedagogia, estudava, na época só tinha o Dom Bosco aqui, não tinha aquela faculdade.

Então mãe quero fazer pedagogia, quero fazer história, você vai fazer...á mãe num sei tem que pagá, não, eu vou trabalhar, eu vou pagar sua faculdade e na época o André Puccinelli era vereador foi... foi paraninfo dela...André Puccinelli né, e ela adora ele. E assim fui criando, aí veio mais a caçula, que também, né, eu quero fazer Historia, ta cê vai fazer história, estudava a noite e trabalhava de dia, a mais velha nunca trabalho fora porque não dava tempo então nunca trabalho fora, e eu trabalhei e criei meus filhos assim, cansei de trabalhar lá no quartel fiquei doente e fui dar marmita em casa tinha dez marmita, prá pagar a faculdade...do estudo, então o que eu falo pra ela, minha filha o que você aproveita é o estudo que eu posso dá, eu não estudei, eu tenho até a quinta série mas vocês vão estudar, hoje em dia ela a mais velha tem a casa própria dela, ta muito bem com o marido, o marido é muito bom, ele ganha bem, 
ela ganha bem, ela tem um carro e ele tem outro carro, a mais nova ta morando lá no Eudes Costas comprou um apartamento, tem um filha de 11 anos e também não quer mais (risos) ta na terceira série, sexta série, e ela ta fazendo...o que direito. E eu tô aqui, tô vivendo, não morri de trabalha, moro com a mais velha me levou pra lá, pra leva lá...a Senhora não vai morar sozinha que aí eu tinha minha casa montada, aí ela falou não a Senhora não vai ficar sozinha, a Senhora vai morar comigo, tem a minha casa mandei fazer o quarto da Senhora com banheiro com tudo e moro lá com ela...E SOU FELIZ E MUITO MUITO MUITO FELIZ, e esse homem que me largou, hoje em dia ele tá morrendo e sabe quem cuida dele o meu filho mais...o meu filho que eu criei, que ele não quis ajudar, o Marcos ele ta lá morando com o pai dele pra cuida, tá morrendo porque tá cego das duas vistas...tá....podre de...de....como chama esse que não pode come açúcar, Diabetes, um pouco na cadeira de rodas, outro pouco sem cadeira de roda, tá vivendo. E a minha filha mais velha que era agarrada com ele chora, eu digo que não adianta você chora porque ele largou você dormindo no chão então minha filha tem que espera chega o dia dele, ele ta..., ta colhendo o que ele planto, mas tá colhendo bunitinho mais muito bunitinho, por que a mulher dele ta cuidando dele que ta com ele é uma bruxa, vô ti fala bem a verdade, ela era muito branca, branca, bunduda, bunduda, hoje em dia ta pelanca, ela ta..ela sofre com ele, tem que leva pra toma banho, tem pô cumida na boca, ele num fala, ele num anda ta com as pernas dura, tudo isso. Então ele ta colhendo, e eu? To bem, eu me sinto bem, to feliz da vida, vivo feliz to lá com meu neto, brinco com meu neto, tenho meu dinheiro, sou aposentada pelo INSS, quando eu quero saí, eu saio, quando eu quero viaja, eu viajo, quero come um negocio, eu compro e como, e tô vivendo...e ele? Ele num pode nem come ta cheio de..de..de negocio de Diabetes de..de..num pode comê as coisas e ele é feliz?, num é, nem dinheiro, mais num é feliz, porque ele aposentou muito cedo pelo estado então ta cego das duas vistas, ele é feliz? Num é, EU SOU e..e.. isso aí e..e nessa foi passando e passando, a idade, quantos anos a Senhora tem? Eu tenho tanto....eu tenho $70 . . .70$ mais num brinca que a Senhora tem...tenho, o que a Senhora faz? Eu falei num faço nada, vou vivendo, num esquento hoje em dia num esquento com nada minha filha com nada, como o que eu posso come eu como, tenho, né, cardiologista, faço tratamento com ela, tomo meus remédios, né, e vô vivendo e agora cheguei aos 73 e em agosto vou fazer 74, num sei se vô chega lá mais se num chega eu já to bem com Deus, Graças a Deus e é isso aí, tá bom, valeu? 


\section{Entrevista 09: BORBOLETA 9 (66 anos)}

-Bom dia, Maria da Graça! Primeiramente é um prazer imenso estar participando e colaborando nesse trabalho seu. Ė... principalmente, porque na verdade, EU sou enfermeira, fui enfermeira durante muitos anos, na minha mocidade, sou enfermeira instrumentadora e obstetra. E por isso eu louvo o seu trabalho. É...quanto ao... a sua pergunta, né, de como é ....(repito a pergunta) o que é e como é chegar aos 66 anos de idade. Eu posso ... eu sempre digo que eu não gosto quando dizem que eu pertenço a melhor idade, por na verdade, pra mim a melhor idade é aquela que nós estamos vivendo, é o presente, qualquer que seja, independente da idade cronológica. E... envelhecer, como costumam falar, eu cheguei nessa idade, eu só tenho que agradecer, primeiro a Deus, pela oportunidade de chegar até este... essa idade. E tudo é experiência, conhecimento e elucidação do quê que é a vida e quais são as nossas necessidades, os nossos deveres e os nossos direitos. Eu nunca tive discriminação, como eu vejo muitas amigas dizerem que está... está tendo discriminação por ser pessoa de idade. Eu nunca encontrei essa discriminação em ninguém, nem nos jovens, nem nos colegas. Por isso, eu acho que eu não sou bem a pessoa indicada assim para dizer como é envelhecer, porque na verdade eu não sinto que eu estou envelhecendo, eu sinto que eu estou vivendo e adquirindo cada vez mais experiência. 


\section{Entrevista 10: SABIÁ (69 anos)}

-Bom, significa pra mim..é.. procurar uma boa... (parece procurar as palavras), uma boa convivência, uma boa experiência, no fato da... da nossa pouca existência, que eu penso assim. Porque o homem, desde o início da história, ele não foi... é... criado para viver apenas 60, 70, 80 anos de idade. Nós temos uma motivação da eternidade, né, que Deus nos deixou já inerente ao homem desde a primeira criação. Assim como um fabricante fabrica um... carro segundo o propósito dele, é um carro, se usar, por exemplo, dentro da técnica, ele terá uma existência bem ampla e se possível dentro do dado dele de perfeição. O homem então é para viver uma vida eterna, e nós temos esse desejo de viver uma vida eterna. Agora porque que o homem envelheceu, ou morre, né? Do ponto de vista de uma falha dele mesmo, inerente dele, porque ele... até o nenê quando se nasce, papai e mamãe olha e vê uma condição perfeita no nenê, mas devido a convivência dele, a maneira de se viver, ele pode degradar, há uma degradação tanto física como moral, e psicológica, emocional e assim por diante, dependendo agora da condição que ele vive. Então eu acho assim, então quanto mais nós vivemos nessa terra é sinal que nós tamos na trilha melhor, melhores condições, tanto psicológica, física, mental, etc. Então é nesse sentido, né. O homem não foi feito para viver, penso assim, então é uma.., é um trunfo, é uma glória a gente viver quanto mais possível, né. Ter um bom relacionamento...familiar, um bom relacionamento social entre as pessoas e principalmente uma boa consciência para com Deus, porque ele que é o autor da vida, não é o homem que é o autor da... existência humana. È esse ponto que eu tenho. Agora estou aqui nessa convivência dos idosos porque eu acho que cada um tem uma experiência positiva na vida, né, apesar das...das inconveniências que passou durante um tempo,mas, de existência dele, mas ele tem um, algo importante pra suprir pra cada um de nós, então nós aderimos a essas informações, essas orientações é... é ... positiva de cada um e como um todo a gente é beneficiado com tal associação e convivência. Agora falando um efeito que tem a medicina sobre nós idosos, né ou mesmo pessoa de tenra idade, durante a convivência nesse globo terrestre, vamos dizer assim. Eu tenho a medicina como uma... uma maneira, é positiva, assim de querer suprir as deficiências orgânicas, né, até psicológica, mental, moral, porque eu creio muitos médicos eles tratam a pessoa como um todo, não apenas só fisicamente. Então a medicina, ela tem como meio alternativo de preservar a existência humana e manter a...a nossa vida, a nossa convivência. Então é elogiável essa tendência de assim pensarem, de assim trabalharem em prol da existência humana, né, e penso que a pessoa idosa como é, ela é um resultado dum processo de trabalho de longa... de longo tempo, de longa... longa existência, do grande desenvolvimento,né, do passado, do presente, né e até do futuro isso é possível. Então eu 
penso assim que é elogiável a preocupação que tem, né de quer manter a espécie humana aqui na terra, com também até os animais, também, a medicina também tem concorrido para isso, manter os animais na terra. É isso aí, obrigado. 


\section{Entrevista 11: BORBOLETA 11 (77 anos)}

- Bom dia, olha minha filha chegar aos 77 anos praticamente, eu nem sei dizer pra você, eu acredito com eu tenho 77 anos e as pessoas dizem e olham pra mim até e dize que não tenho por que o meu espírito não é de 77 anos, eu tenho uma vontade de viver, de faze, de anda, de participa de tudo que eu posso, né. Eu acredito que seja pela......pela...como é que eu falo, pela nossa criação, eu vim de uma, de uma família meu pai era palestino assim muito opressor, muito rigoroso, né, com a nossa educação com tudo aquilo. Casei também do mesmo jeito naquele tempo, né, que a mulher não tinha tanta liberdade, não tinha sua independência financeira, eu não tenho uma independência financeira ao não ser meu, meu beneficio que eu recebo de 1 salário, mas é suficiente porque eu me casei, sou uma mulher hoje divorciada de.....já faz uns....perto de 40 anos, mas eu tenho 2 filhos que me dão essa é minha alegria de viver então eu acho o que me faz chegar a esse ponto aqui é a minha liberdade de vida, o respeito que eu tenho de meus filhos, né, eu tenho ótimas amizades, procuro freqüentar aqui (CCI) uma ginástica, uma....uma.....uma qualquer reunião que seja eu procuro estar, né, não fico sozinha em casa, né, faço todo meu serviço da casa procuro fazer, né, que é prá isso mesmo, pra não ficar muito parada, né, então eu acho que é isso.

- Ah, ah....o envelhecimento hoje em dia e hoje também a gente está tendo muita vantagem, né, porque....porque estamos assim como você, esta se interessando com seu grupo, está se interessando como que é nossa vida e o respeito também que já estão tendo por todos nós, pelo idoso, né, pela facilidade, né, e de..de....de recursos de saúde, né, a gente tem muito mais....muito mais.... assim é .....cuidados, né, temos, hoje pelo menos eu não posso me queixar, onde eu vou, eu tenho sempre cuidado com as pessoas comigo tem as filas próprias pra no banco, em tudo qualquer lugar a gente tem, não podemos reclamar, eu não posso reclamar de nada hoje, na nossa idade hoje é muito respeitado, né, até pelos jovens mesmo já estão começando a enxergar a gente diferente, né, com toda essa campanha que fazem que estão tendo hoje, olha, aqui ou onde qué que a gente vá, a gente tem...tem cuidado, tem respeito, então eu acho que é isso que faz a gente que chega esse ponto, né, hoje oitenta anos é...é praticamente vou te dize eu ainda tenho oitenta anos... ainda tenho, né, não dize eu já tenho oitenta anos e eu vou para, não, nossa é uma coisa maravilhosa, eu acho que é simplificando em tudo é a liberdade de vida que nós temos hoje, antigamente com 40 anos se fazia uma pituquinha, não é mesmo e....já...já não tinha mais condições, né, de...de...de nem por uma roupa mais...mais com cores mais alegres e mais aberta, não podia, então é isso eu acho são todas essas coisas, alimentação, hoje nós temos mais orientação, né, aqui mesmo nós 
outro dia nos tivemos uma palestra sobre nutrição, é bom ter uma orientação sobre isso..e..e...e então eu acho que é isso, né(risos). 


\section{Entrevista 12: MARIPOSA 12 (74 anos)}

- Olha chega aos 70 anos...74 anos de idade é bom tendo saúde...saúde, paz em casa como Graças a Deus eu tenho, sou muito bem com meus filhos, com meus netos então eu me dou muito bem eu acho que chega essa idade é uma...uma beleza.

\section{Entrevista 13: BORBOLETA 13 (83 anos)}

- Olha, envelhecer a gente vai envelhecendo e não está...e não vai sentindo, sabe, e a gente vai naquela felicidade da vida, tudo bem, tudo maravilhoso, né, aí quando a gente chega certas idades como eu tenho já 83 anos, aí que a gente vai sentir, a junta mais duras, os ossos pesados, sabe, então a gente....eu mesmo dá trabalho pra mim calçar meia, sabe, pra mim me vestir não, mas pra calçar meia me dá um trabalho só se você vendo e marrá também o cadarço do tênis também me dá trabalho, é o que eu sinto é isso então por isso que eu venho todos os dias aqui na convivência e me sinto me bem, me sinto feliz, eu moro com o meu filho, né, eu sou sozinha então eu moro com o meu filho já sou viúva já faz 26 anos então eu moro....meu filho, fez uma casa.....dois quartos lá pra mim, sala , não.....cozinha e quarto, eu estou bem Graças a Deus, então é a minha felicidade é essa, saúde também eu não sou muito assim...boa saúde, eu tenho que toma remédio pra controlar a pressão porque a minha pressão ela não é alta é baixa sabe, eu preciso toma esse remédio todos os dias...todos os dias pra controla a pressão, e agora eu não sei o que eu vou falar pra você mais. Então a gente agora nós estamos aqui fazendo esses trabalhos, ginástica todas essas semanas, trabalhos manual e de maneiras que eu me sinto muito feliz, eu dou parabéns pro Juvêncio que foi o primeiro que fez essa convivência aqui, eu já faz 11 anos que eu estou aqui e agora como nós vamos muda eu tô pensando muito como será que vai sê, né , aqui tão pertinho eu não dependo de ônibus, eu venho ali de casa a pé e agora quando nois for pra lá tem que depender de ônibus isso é que vai se difícil pra nós, eu mesma na minha parte ficaria aqui a vida toda, né, mas num tem jeito, é. 


\section{Entrevista 14: BORBOLETA 14 (66 anos)}

- Eu acho que pra mim chegar nessa idade foi tudo uma formação de berço, se a gente não tem berço a gente não consegue chega onde a gente chegou, de família simples mas tive tudo carinho, amor, atenção nunca me faltou nada mas comecei com uns treze anos trabalhar pra fora já e estudar a noite, na nossa época era difícil o estudo, hoje as coisas estão muito fáceis e as pessoas não querem nada, e nós não, nós enfrentamos....eu sou da capitão de São Paulo então é outra mentalidade daqui do pessoal de Campo Grande, né, outra visão completamente diferente então eu acho que tudo vem de berço e com a luta do dia a dia, casei, crie 3 filhos meus e adotei uma, até hoje eu sou assim muito ativa, né, gosto de dançar, brincar, jogar, conversar, fazer amizades, mas no fundo eu sou deprimida, né, parece... parece incrível falar, né, o pessoal fala eu não acredito mas eu não posso fica sozinha não eu tenho que estar sempre articulando.

- Tem um item dentro desse trabalho que você está fazendo que eu não gosto, quando a pessoa diz a melhor idade, porque como que pode ser a melhor idade quando você se olha diante de um espelho e vê... o cansaço no teu rosto? Você plenamente uma coisa e quere faze e não consegui mais e não tem condições físicas, mentais, espirituais pra faze um trabalho, então eu acho que a pessoa é uma idosa, uma pessoa mais velha esse negócio de melhor idade... eu acho que é careta, sabe, no meu ponto de vista, porque não é bonito não, não é, não é fácil a gente se olhar no espelho e vê já o peso da idade, de querer faze, fica dependendo, eu ainda não to dependendo, eu sou muito auto suficiente ainda, né, com 66 anos, mas tem pessoas até com menos idade do que eu que depende totalmente das pessoas, isso é horrível uma pessoa que sempre fez tudo acho que é por isso que eu gosto de participa pra mim num...num caí, né, porque se você pará você acaba mesmo, né, tem que batalha, eu jogo bocha, eu jogo canastra toda semana com as minhas amigas, dominó, tudo que você pode imaginar, fui escoteira 25 anos, né, então trabalhei com jovem muitos anos, então eu ainda tenho muita coisa ainda pra dá dentro de mim, mas enquanto eu tiver força, porque quando eu pará memo que não puder mais..., a velhice eu não posso impedi, né, ela tá chegando mas que eu não gosto eu não gosto não...(risos).

- Então, como pessoas têm pena do idoso, vive carregando, segurando, não é isso!Idoso é idoso, ele tem que vive, ele tem que... que percebe que ele é gente ainda, né. Esse negócio do ônibus lá, cartaz, reservado, não deveria existir, apenas as pessoas deveriam ser educadas, que não haveria necessidade disso hoje, não é verdade?

Entrevistador: $\grave{E}$ 
- Mas não, fica os jovens hoje com birra dos velho, porque que velho sai na rua, não porque velho sai na rua, velho é gente, eles que não tem educação, quer dizer não tem família.

Entrevistador: Não sabem que vão chegar lá também.

- Exatamente, não sabem que vamos passar pelas mesmas coisas que a gente está passando, hoje eles vão chega também, né, e é assim a vida do idoso.(risos) 


\section{Entrevista 15: BORBOLETA 15 (67 anos)}

- Olha, eu...eu acho que chega nessa idade o principal é a pessoa ter saúde, né, ter o bem estar, viver bem com a família, vive em paz consigo mesma e eu acho que isso é o mais importante, né, acredito que a saúde é uma coisa muito importante, é... e agora a gente participando aqui dessa...dessas atividades aqui no horto a gente se sente muito bem, eu... eu digo assim por experiência própria porque a uns....eu comecei há 1 ano atrás, fique viúva há 2 anos, né, aí minha amiga me convidou pra participa das atividades aqui e é uma coisa muito boa, a gente só tem a ganhar com isso aí, por que faz novas amizades, né, e é muito bom a gente fica mais até...mais social, né, se introsa com as pessoas que aqui estão, né, e eu acho muito bom isso, aí, to sempre aqui e me dou muito bem aqui no horto, todas as atividades aqui que nós fazemos.

(Falou muito após a gravação, expôs sua vida, inclusive conjugal antes da viuvez (os problemas de saúde do esposo, que impediam a continuação da vida sexual por 10 anos, a separação de leito); a carência atual de um companheiro, de companhia, e um carinho, a possibilidade de arrumar um namorado, devido o reaparecimento de um antigo amor, da década de 50 (1956); a oposição dos filhos; a vontade de viver em casa separadas, mas mantendo um relacionamento (momentos de muita emoção, inclusive da pesquisadora, com a disposição da entrevistada em abrir sua vida). Pediu para conversarmos outras vezes, para além da pesquisa.) 


\section{Entrevista 16: MARIPOSA 16 (68 anos) (registro escrito devido falha no gravador)}

- Acho muito bom!Há cinco anos faço os exercícios. Eu era uma pessoa muito nervosa, morava na chácara, trabalhei muito, tenho convivência boa com o esposo. Tenho três filhos: um trabalha no escritório da prefeitura, outro é arquiteto e o outro trabalha na governadoria. Tenho boa convivência com as pessoas. Gosto de fazer os exercícios, é muito bom pra saúde! È a melhor coisa que fizeram pra nós. Fazer os exercícios ajuda a conhecer outras pessoas, fazer novas amizades, ter liberdade. Venho aos bailes, meu esposo $\mathrm{n}$ ao me acompanha. Gosto de baile, a dança faz muito bem pra gente, é a melhor terapia. É um ambiente bom, confortável, todos vivem bem, ninguém fala do outro. Não pode ficar só dentro de casa, a mente tem que se ocupada.

\section{Entrevista 17: PARDAL (76 anos) (seqüela leve de AVE à esquerda)}

(Antes de autorizar a gravação falou durante aproximadamente 40 minutos para contar a história do "derrame", alternando com fatos de sua vida; falou sobre a possibilidade da morte “tudo que nasce morre, se não vai de pequeno, de velho não escapa!") Quando mostrei o gravador e pedi para falar sobre o que é envelhecer, a inibição foi nítida e falou pouco.

-Oh, envelhecer é o seguinte: a pessoa nunca deve ficar parada, ele tem que ser alegre, certo? Ser uma pessoa... brincar com outros, não ficar pensando maldade na cabeça. Uma coisa pra envelhecer é quem fuma, envelhece mais, ficar sem dormir prejudica muito... fica a pessoa... fica velha antes da hora. Agora, a pessoa sempre brincar com os outros, rir, descarrega tudo que tem por dentro; a pessoa sempre consegue a sua vida, sabe contar uma história, sabe contar um causo pro pessoal, porque hoje é difícil é quase o pessoal conversar, contar um causo, contar estória, né. È isso que eu tenho que fica pensando que deixa a pessoa envelhecer; agora se a pessoa ficar parada pensando, cabeça baixa, tiver... ainda mais muito que fuma, gosta de beber muito, de fumar, aí o bicho pega! Acredito que é só isso que eu tenho a dizer pra você! 
5. As possibilidades de ser com o envelhecimento

"Na velhice darão ainda frutos, serão cheios de seiva e de verdor."

(Pr. 92: 14) 
$A$

ntes de iniciar a análise dos registros, quero compartilhar o momento em que me senti aceita no CCI "Elias Lahdo". Estava presente entre eles há cerca de um mês e, um dia, fui convidada a fazer a oração final do encontro diário. A meu ver, era um momento especial para eles e significou muito para mim. Já no CCI "João Nogueira”, o processo foi mais lento, porém, também me senti aceita quando comecei a ser menos pesquisadora e mais pessoa na convivência com os freqüentadores do local, isto é, falava mais de mim e da minha vivência profissional e menos do motivo de estar ali. Então, pareceu-me que a aproximação foi acontecendo naturalmente.

Foi preciso disponibilidade para voltar várias vezes aos locais e aguardar para ouvir aqueles que quisessem participar. Não podia interferir na rotina diária dos centros de convivência e fui habitando um mundo novo e diferente para mim, longe da dor, sofrimento e morte, tão presentes no hospital. Gente alegre, vivendo seu momento, cheia de vitalidade, com problemas, mas sendo um exemplo de força e coragem.

Antes de iniciar as gravações, quando havia momentos de conversa informal, eu anotava alguns dados do entrevistado e buscava conhecer um pouco de sua vida, de seu mundo. Foram momentos ricos, de descoberta, nos quais cada um colocava-se livremente e contava histórias de suas vidas, às vezes emocionando-se muito. Nesses depoimentos, que não eram gravadas, havia espontaneidade, sinceridade, confiança e muito daquilo que foi dito revelou facetas não expostas nas entrevistas registradas.

Passo, neste capítulo, a explicitar as possibilidades do viver o envelhecer, conforme captado nos depoimentos dos idosos.

No decorrer do desenvolvimento do estudo, fui aderindo ao pensar de autores para os quais o envelhecimento é parte da vida e, assim, optei por ler os depoimentos com 
aproximação a algumas idéias de Martin Heidegger, especialmente aquelas referentes às suas idéias sobre a analítica da existência humana, como as temáticas de homem, mundo e cuidado.

Para melhor compreensão desse referencial filosófico, optei por trazer conteúdo das obras do próprio Heidegger e também de outros autores que estudaram este referencial e nele fundamentaram seus estudos.

Heidegger contrapõe a noção de mundo a de terra. Para ele, tais termos são metáforas, com terra designando o elementar, o primordial e mundo sendo o que se organiza, se articula, o que toma forma sobre o fundo do elementar e em relação a ela (FIGURELLI, 2005, p. 123) (grifos no original).

Corrêa (2000) refere que o ser-com é interpretado por Heidegger como cuidado, ou seja, o homem como ser-no-mundo é essencialmente cuidado; o ser-aí é cuidado.

Para entendiemnto que o homem, antes de ser pre-sença, é cuidado, Heidegger recorre a uma antiga fábula, Fábula de Higino - Alegoria do Cuidado:

Certa vez, atravessando um rio, Cuidado viu um pedaço de terra argilosa; cogitando, tomou um pedaço e começou a lhe dar forma. Enquanto refletia sobre o que criara, interveio Júpiter. O Cuidado pediu-lhe que desse espírito à forma de argila, o que ele fez de bom grado. Como Cuidado quis então dar seu nome ao que tinha dado forma, Júpiter o proibiu e exigiu que fosse dado o seu nome. Enquanto Cuidado e Júpiter disputavam sobre o nome, surgiu também a Terra (tellus) querendo dar o seu nome, uma vez que havia fornecido um pedaço de seu corpo. Os disputantes tomaram Saturno como árbitro, que pronunciou a seguinte decisão, aparentemente justa: “Tu, Júpiter, por teres dado o espírito, deves receber na morte o espírito e tu, Terra, por teres dado o corpo, deves receber o corpo. Como, porém, foi o Cuidado quem primeiro o formou, ele deve pertencer ao Cuidado enquanto viver. Como, porém, sobre o nome há disputa, ele deve se chamar "homo", pois foi feito de húmus (terra) (Heidegger, 2005, parte. I, p. 263-264).

Por meio desta alegoria do cuidado, Heidegger expressa que o homem pertence ao cuidado enquanto vive, isto é, no transcorrer de seu percurso temporal no mundo 
(determinado por Saturno, deus do tempo) e, desde a sua origem, vem a concepção de que ele é composto de corpo e espírito (HEIDEGGER, 2005, parte I).

A partir dos depoimentos, interligados às minhas vivências, pessoais e profissionais, e às observações que emergiram do meu conviver com essas pessoas, um envelhecimento distinto daquele preconcebido, foi apresentando-se a mim nas suas diversidades possíveis de ser.

Segundo OMERY (1983), a leitura da descrição inteira da experiência é realizada para obter uma percepção do todo. Fiz a leitura atentiva dos relatos para apreender as unidades da experiência - constituintes. Para tanto, evidenciei mensagens explícitas e implícitas, pinçando os significados atribuídos pelo sujeito ao fenômeno investigado. Nesse momento, associei ao processo lógico de análise, a reflexão intuitiva, sensível, para captar as esferas subjetivas do fenômeno. Procurei eliminar redundâncias nas unidades, clarificando ou elaborando o significado das unidades restantes pela relação delas com cada outra e com o todo.

A interpretação dos depoimentos possibilitou a compreensão de parte da essência do fenômeno investigado, sem perder a riqueza da subjetividade de cada entrevista. A análise dos dados foi feita em busca da essência, do des-velamento do que se mostrava oculto.

Carvalho (1987), citando texto da professora Telma A. Donzelli, esclarece que "ao contrário do método científico, o fenomenológico não busca um invariante no sentido do que não varia e, por esta razão, a fenomenologia não é uma ciência exata. Busca-se o invariante no sentido do que é impossível à consciência pensar de outro modo e, por isso, a fenomenologia é uma ciência rigorosa, uma vez que contempla o caráter fluente e variável da vivência."

Segui os quatro momentos de análise propostos por Martins e Bicudo e explicitados por Boemer (1994), fazendo inicialmente a leitura completa das descrições, com vistas a ter 
um sentido do todo, procurando os significados atribuídos pelas pessoas ao seu processo de envelhecer.

A seguir, li novamente os relatos, buscando identificar unidades de significados, a partir da minha perspectiva como enfermeira. Assim, foi sendo possível uma "apreensão mais abrangente do fenômeno", que passo a descrever com fragmentos dos depoimentos das pessoas.

\section{VIVENDO A VIDA}

Neste desvelar, percebi que as pessoas não se sentem envelhecendo, mas continuando a viver um outro momento de sua existência, confirmando o pensamento de Simone de Beauvoir, em seu livro sobre a velhice, quando diz que muitas pessoas não se sentem velhas ou envelhecidas aos 60 ou até aos 80 anos de idade:

“-Olha, depende muito da cabeça de cada um, viu! Porque eu não me sinto envelhecida, minha cabeça é livre de preconceitos de envelhecimento...Eu topo tudo, qualquer hora é hora!"(Mariposa 04, 61)

"Eu num me acho velha, eu acho que eu sô jovem, num sinto a velhice. Eu trabalho, eu faço as coisas em casa, eu ainda lavo, passo prá fora...eu continuo trabalhando, eu não sinto canseira, vou prá igreja...é muito bom ficar velho na minha posição: alegre, contente do jeito que eu sô, eu não acho diferença ainda...Num tô diferente do que eu era mais jovem, só a gente é muito pesada porque agora sô mais gorda, sô mais pesada do quê antes(risos)" (Mariposa 05, 73).

“...eu acho que eu não sou bem a pessoa indicada, assim, prá dizer como é envelhecer, porquê na verdade eu não sinto que eu estou envelhecendo, eu sinto que eu estou vivendo e adquirindo cada vez mais experiência"(Borboleta 09, 66). 
Tavares (2005, p.104) traduz tal situação como um conflito, expresso no seguinte questionamento: "se o modelo de velhice sempre foi o de declínio físico e psicológico e afastamento do mundo social, quem sou eu, que chego aos 60 com vitalidade e necessidades sociais?" Segundo a autora, para uma resposta é preciso considerar a singularidade dos indivíduos como sujeitos da experiência e, baseada em algumas idéias de Heidegger, essas pessoas estão em um estado de absoluta liberdade, pois enquanto conseguem assumir com propriedade o seu "ter-de-ser" idoso, isto é, assumem a responsabilidade e o peso de, como seres lançados no mundo, vivenciarem seu envelhecer.

Segundo Beaini (1981), o homem é um ente único e distingue-se dos animais e das coisas por que fala, mas ainda assim, é um ente (entendendo-se por ente tudo o quê pode ser encontrado no mundo físico). Heidegger diz que tudo no mundo é ente e todo ente tem um ser que permite que eles sejam entes. O Ser dos entes não aparece em si próprio, precisa ser des-velado, mostrar-se além daquilo que esta à vista, imediatamente dado. "O Ser é enquanto luz que des-vela o ente e dá a captá-lo” (BEAINI, 1981, p.22).

Compreendo assim as pessoas entrevistadas, por que elas trazem em si o ser como a essência do ente que somos e de tudo o que é. Por meio da fala, que é própria somente do homem, busquei acessar o Ser deste ente; no entanto, não o captei, mas a manifestação deste Ser no ente que me foi apresentado.

O homem tem acesso aos entes e também tem consciência de si, estando em interação com tudo o que o cerca, participando do mundo, apresentando e manifestando suas experiências.

O que caracteriza essencialmente o homem é o fato de poder relacionar-se com o ser. Enquanto é aberto a tudo o que o cerca, o homem existe em meio aos demais entes, mantém um contato contínuo com eles - sendo que este modo de ser assinala a própria condição humana (BEAINI, 1981, p. 28). 
Assim, o homem deixa as coisas serem, manifestarem-se em suas essências, sendo alguém no mundo, sem o qual não poderia ser o que é. Para Heidegger, a essência do entehomem está na sua existência, ou seja, o ser-aí/Dasein, a maneira do homem ser no mundo, que é diferente do modo de ser dos entes simplesmente dados. A palavra existência resulta da aglutinação da preposição ek e do verbo sistere e, para Heidegger, "existência" designa toda a riqueza das relações recíprocas entre pre-sença e ser, entre pre-sença e todos os outros entes, por meio de um ente privilegiado, o homem. Nessa acepção, só o homem existe; a pedra é, mas não existe (HEIDEGGER, 2005, p.310).

Steiner (1978) analisa as idéias de Heidegger e diz que o Dasein (o ser-aí) é "aí” no mundo concreto, literal, real e cotidiano. Ser humano ("humano" - "húmus" = "terra") é estar imerso, implantado, enraizado na terra, na trivialidade cotidiana do mundo, no aqui e no agora e em toda parte à nossa volta. Compreender a presença do outro é existir. Ser-nomundo para Heidegger é ser-com.

Forghieri (2004, p. 17) diz que:

$\mathrm{O}$ eu vive no mundo, mas não se encontra delimitado àquilo que vivencia no momento atual, pois pode, também, dirigir seu pensamento para o que já vivenciou anteriormente, assim como para as prospecções que faz em relação a coisas que tem a expectativa de vir a vivenciar.

Beaini (1981) refere que o homem é ser-no-mundo humano. Mundo não no sentido de universo, como um conjunto de todas as coisas, mas o mundo humano, constituído pelo ambiente no qual o homem é (contexto existencial), pelas coisas significadas neste mundo (estrutura de significação) e mundo como parte do homem, numa relação essencial daquilo que o homem é e do sentido de seu ser-no-mundo. O significado das coisas emerge à medida que o homem estabelece ligação com os outros e com o mundo.

O que faz o homem ser-no-mundo é o relacionamento com o ser, que propicia a Linguagem. Porque os entes, diferentes do homem, estão fechados em si, acabados, sem mundo, não têm linguagem (BEAINI, 1981,p. 30). 
O estar-lançado na velhice abre-se em diferentes possibilidades e é a partir delas que o ser-no-mundo projeta-se para o futuro. O ser-projeto pertence ao poder-ser mais próprio de cada pessoa (HEIDEGGER, 2005, parte I, p. 290).

\section{BUSCANDO A CIDADANIA}

Por isso, mais do que leis e políticas públicas, quase sempre inexeqüíveis, essas pessoas esperam respeito e dignidade da sociedade onde vivem, conforme encontramos em alguns depoimentos:

“...como pessoas têm pena do idoso, vive carregando, segurando, não é isso! Idoso é idoso, ele tem que viver, ele tem que perceber que ele é gente ainda... Esse negócio do ônibus lá, cartaz, reservado, não deveria existir, apenas as pessoas deveriam ser educadas, que não haveria necessidade disso hoje, não é verdade?"(Borboleta 14, 66)

“...eu não posso reclamar de nada hoje, na nossa idade hoje é muito respeitado, até pelos jovens mesmo já estão começando a enxergar a gente diferente, com toda essa campanha que fazem, que estão tendo hoje,..., aqui ou onde quer que agente vá a gente tem...tem cuidado, tem respeito, então eu acho que é isso que faz a gente chegá a esse ponto"(Borboleta 11, 77).

Heidegger (1981) discorre sobre a "solicitude" existente no ser-aí com os outros, enfatizando que o ser contra o outro, o ser sem o outro, o "passar" pelo outro, o não importar-se com o outro, são modos possíveis, porém inautênticos de solicitude.

O aparato legal que trata das questões da pessoa idosa pode ser um modo de solicitude que assume o encargo de cuidar do outro, mas de uma forma dominadora, tornando-a dependente, ainda que de maneira oculta. 
Em contraste a esse modo de solicitude, há um outro que não consiste em "saltar sobre o outro", mas de "antecipar-se" a ele em sua existencial possibilidade-para-ser, cuidando da existência do outro, interessando-se por ele.

Estar engajado na luta por seus direitos remete ao conceito de Heidegger de estar-nomundo, no sentido de participar, empreender, realizar, interrogar, examinar, discutir e saber sobre o que é ser velho na sociedade em que vivemos, pois o ser-aí só se descobre quando apreende a realidade (STEINER, 1978).

As situações vividas são relatadas pelo modo peculiar de cada pessoa entrevistada; cada uma compreende sua experiência a partir da sua vivência. Porém, existem aspectos comuns na existência de cada uma dessas pessoas, pois elas compartilham uma realidade concreta, ou seja, são pessoas consideradas idosas, convivendo numa sociedade que ainda não as reconhece plenamente como parte ativa.

A respeito da atenção à população idosa, Silva (2005) destaca que, no Brasil, antes da década de 70, o trabalho realizado com idosos era de cunho caritativo, desenvolvido por ordens religiosas ou entidades leigas filantrópicas. As políticas públicas também tinham caráter paliativo e fragmentário, pois não abrangiam, em sua plenitude, uma noção ampla dos direitos sociais dos cidadãos.

A Política Nacional do Idoso (PNI), a Lei 8.842/94, regulamentada pelo Decreto 1948/96, estabelece direitos sociais, garantia da autonomia, integração e participação dos idosos na sociedade, como instrumento de direito próprio de cidadania, sendo considerada população idosa o conjunto de pessoas com 60 anos ou mais.

No entanto, Silva (2005) ressalta que o usufruto dos direitos sociais só pode ser garantido com a efetiva participação política da população por meio dos instrumentos de organização, pressão e denúncia. Vale salientar que a velhice não torna um ser humano menos ou mais importante que os demais cidadãos, porém, o caráter débil e a falta de 
respeito aos direitos humanos e sociais no Brasil, colocam os idosos numa posição crítica, visto os cuidados específicos exigidos neste momento da vida.

Portanto, conclui esta autora, do ponto de vista da normatização legal, o envelhecimento é protegido no Brasil, havendo diretrizes a serem seguidas e implementadas. Entretanto, isso não é suficiente para assegurar a plenitude desses direitos. Desse modo, a mobilização e a participação dos idosos, em todas as frentes, quer seja nos partidos políticos, associações de aposentados e pensionistas, confederações, centros de convivência, enfim, nos mais diversos espaços da vida social, são fundamentais como formas de resistência às ações políticas que insistem em negar direitos conquistados de forma árdua pelos movimentos sociais de aposentados, nas décadas de 80 e 90.

A participação efetiva das pessoas idosas, mostrando sua força política, organizandose, criando parcerias e alianças com representantes dos poderes legislativo, executivo e judiciário, organizações não-governamentais (ONG), entre outros órgãos tanto da esfera civil como governamental, poderá contribuir de forma significativa para reverter "a morte" da lei escrita e convertê-la em realidade.

\section{REALIZANDO SONHOS}

Ultrapassando os limites socialmente impostos para as idades mais avançadas da vida, essas pessoas encaram a velhice como propícia para o prazer e para a realização de sonhos adiados em épocas anteriores:

"Prá mim tá sendo ótimo. Tô ...tô bem melhor agora do quê quando eu era mais nova, sabe! Porque agora pelo menos, eu já sinto realizada já!” (Borboleta 06, 65)

"Tô bem, eu me sinto bem, tô feliz da vida, vivo feliz, tô lá com meu neto, brinco com meu neto, tenho meu dinheiro, sou 
aposentada pelo INSS, quando eu quero sair, eu saio, quando eu quero viajar, eu viajo, quero comer um "negócio", eu compro e como, e tô vivendo"(Borboleta 08, 73).

Percebo aqui a pessoa em busca de algo que ainda poderá ser para completar-se ou totalizar-se. Como relata Forghieri (2004, p.44), o “existir implica, para o ser humano, em prosseguir em direção ao futuro, cuja abertura de possibilidades não se limita a uma projeção do passado".

A autora ressalta que:

A abertura de possibilidades e a esperança de concretizá-las ilumina e amplia tanto as perspectivas futuras como as lembranças do passado, enquanto o desespero e o desânimo as obscurecem podendo chegar a encobri-las completamente (FORGHIERI, 2004, p.45).

Ter a expectativa de um futuro melhor, realizar sonhos, fazem parte da existência humana. A liberdade de escolher é tanto maior quanto mais ampla for a abertura do ser humano à percepção e compreensão de sua vivência no mundo.

Segundo Steiner (1978), desejo e esperança são o cuidado e a preocupação voltados para o futuro. Sendo assim, o cuidado subentende e requer "a possibilidade de ser livre".

Há referências à questão da aposentadoria e, nesse sentido, Debert (1997) lembra que, para alguns, a aposentadoria deixa de ser um marco a indicar a passagem para a velhice ou uma forma de garantir a subsistência daqueles que, em decorrência da idade, não estão mais em condições de realizar um trabalho produtivo, passando a ser um momento privilegiado para a renovação pessoal, levando à busca do prazer e da satisfação. A autora completa que, especialmente as mulheres, podem viver de maneira mais gratificante, após a aposentadoria.

\section{CONVIVENDO COM O OUTRO}

Algumas depoimentos expressam um outro lado da velhice, contrastando com alguns dos dramas conhecidos da chamada "terceira idade", trazendo o prazer de viver 
coletivamente nos centros de convivência, valorizando o estar com o outro, numa infinidade de possibilidades de ser:

“...sempre vivo também muito satisfeito, por causa dos amigos que a gente tem..." (Colibri, 78)

“...questão assim de convivência assim com as pessoas prá mim é normal, eu gosto de participar, assim, passear, de conversar com as pessoas, eu não gosto é de ficar em casa parada muito tempo, ficar sentada eu não gosto...eu gosto de conversar com as pessoas, participar das coisas... daqui do centro de convivência, da igreja, da associação" (Mariposa 07, 61).

"Tenho boa convivência com as pessoas. Gosto de fazer os exercícios, é muito bom prá saúde! Fazer os exercícios ajuda a conhecer outras pessoas, fazer novas amizades, ter liberdade!" (Mariposa 16, 68)

De certa forma, os idosos expressam aqui o conceito de Heidegger sobre a presença, pois, para este filósofo, a presença não é apenas e estar num mundo, mas também relacionarse com o mundo, segundo um modo predominante de ser. No mundo dos centros de convivência não há um eu isolado dos outros, há algo que é partilhado com os outros, aberto como possibilidade de encontro.

Ali não ocorre apenas a simultaneidade de sujeitos; eles não estão somente entre outros idosos, estão junto, sendo-com-eles, co-presentes, num encontro de muitos mundos particulares. Então, a convivência no CCI é mais do que a soma de vidas que se reúnem em espaços físicos definidos; ali se mostra, conforme Heidegger, a condição originária do ser, pois ser humano é sempre ser-com-o-outro, é ser como possibilidade de encontrar os outros (HEIDEGGER, 1981, p. 35). 
No mundo dos centros de convivência que visitei o ser-com-o-outro se expressou na interação entre os participantes, na solidariedade, no apoio entre eles, partilhando alegrias e tristezas, conquistas e decepções, superação e fracasso. Percebi o cuidado entre eles nos momentos em que um incentivava o outro para continuar as atividades, para aprender uma nova coreografia, para participar de uma oficina, palestra ou viagem.

O cuidado apontado por Heidegger contempla o modo autêntico de cuidar dos entes. O ser-aí preocupa-se, de modo a ter consideração, paciência, expectativas, como cabe também falarmos da indiferença, da dominação, da impaciência, da apatia, da competitividade, entre outros. O sentido do cuidado é amplo e estará fortemente relacionado ao sentido que esses entes exibem na nossa existência, sempre entrelaçados ao co-existir, pois o ser-aí é fundamentalmente "ser-no-mundo". (COLPO, s/d)

Procurei entender este mundo a partir das relações entre as pessoas que ali habitam, investigando os seres-no-mundo cotidiano, na perspectiva fenomenológica, no contexto de fato de onde elas vivem enquanto presença, trazendo para dentro dele sua existência e sua essência.

Os idosos buscam um mundo no qual se identifiquem com outros, não só pelo fator idade, mas também pelas histórias de vida. Nos CCIs que freqüentei, existe um mundo compartilhado entre iguais, ainda que diferentes quanto a gênero, classe social, profissão, situação civil e familiar. Ali surge a possibilidade de viverem, coletivamente, a experiência do envelhecimento, as especificidades e a pluralidade do existir de cada um.

Sobre esta convivência em grupo, Zimerman (2005) refere que um grupo só se torna grupo quando seus membros desenvolvem um determinado tipo de relacionamento, um vínculo, uma força que permite a ele um sentido de pertencer, possibilitando a troca de sentimentos e pensamentos. 


\section{MANTENDO A SAÚDE}

A questão da saúde foi des-velada como uma preocupação das pessoas entrevistadas. Talvez por ser ressaltado, na sociedade ocidental, a relação de reciprocidade entre velhice e doença, a saúde emergiu como algo essencial para se viver bem, citada em praticamente todos os depoimentos. As pessoas idosas, no contexto deste estudo, esperam que a sua longevidade seja acompanhada também de melhor qualidade, para que possam continuar ativas, sem interromper suas atividades.

Colpo (s/d) cita que o sentido do radical grego "pathos", presente na palavra patologia nos remete à limitação, à restrição das possibilidades do ser-aí, tal como ocorre quando se adoece.

“-Olha, chegá aos 70 anos...74 anos de idade é bom tendo saúde...saúde"(Mariposa 12, 74).

“-Olha, eu...eu acho que chegar nessa idade o principal é a pessoa ter saúde, ter o bem estar...acredito que a saúde é uma coisa muito importante" (Borboleta 15, 67).

“...minha velhice "tá” maravilhosa, eu "tô" com saúde...eu sinto feliz na minha velhice, eu tenho saúde" (Borboleta 01, 72).

No contexto, percebo que, mesmo de modo não explícito, a saúde para essas pessoas vai além do bem-estar físico, pois para elas, ter saúde é visto como sinônimo de independência e autonomia, a possibilidade de ir e vir, sem depender de auxílio ou ter que “incomodar" alguém da família, ainda que estejam sob algum tipo de tratamento. Talvez elas também estejam, de algum modo, dizendo que, tendo saúde, não precisam desgastar-se com as dificuldades encontradas para o atendimento no sistema público de saúde, ou seja, são 
poupadas de enfrentar filas, sair em busca dos remédios, correr riscos de sofrer maus tratos ou deparar-se com profissionais sem capacitação técnica e humana para atendê-las. Situações que poderiam ocorrer se necessitassem de atendimento freqüente junto ao Sistema Único de Saúde, uma vez que a maioria dos entrevistados não possui plano de saúde particular e depende dos serviços públicos.

Silvestre e cols. (1996, p. 86-8) fazem uma retrospectiva a respeito das mudanças que vêm ocorrendo nos perfis de saúde da população brasileira, ressaltando a prevalência das enfermidades crônicas não transmissíveis entre os idosos e o alto custo financeiro e social decorrente deste novo cenário. Afirmam que os idosos não recebem uma abordagem médica ou psicossocial adequada por parte do setor saúde, o que acarreta uma inadequada avaliação de suas necessidades.

Segundo Barbosa e Duarte (2001, p. 138), a saúde para os idosos seria a “...capacidade para continuar exercendo funções em seu meio físico e social, com autonomia e independência - expressões de liberdade - contribuindo para a sociedade e interagindo com ela." Sobre este aspecto, Fogaça (1999) ressalta que é importante que os idosos saibam que eles continuam sendo um "ser social” e não apenas um número.

Paschoal (2006) ressalta que, para os idosos, população na qual há um aumento na prevalência de doenças, a dimensão "saúde" tem importância fundamental para a qualidade de vida. Saúde enquanto riqueza da vida cotidiana e determinante do bem-estar, entendida como o equilíbrio entre o meio interno e o externo, com seus processos emocionais, espirituais, sociais, culturais e físicos (OPS, 1993, p. 12 e p.26).

\section{RECONHECENDO A PRÓPRIA VELHICE}

Contudo, as transformações impostas, tanto físicas quanto sociais e emocionais, devido ao prolongamento da vida em anos, não passam despercebidas por essas pessoas e são 
explicitadas pela dificuldade em aceitar o próprio envelhecimento e a dor de ter que reconhecê-lo em si mesmo:

“-Ah! Eu sinto porque a gente... muitas coisas que eu fazia quando era nova agora não posso fazer; a gente vai perdendo as forças, não dá conta de fazer, mas a gente tem que agradecer a Deus por estar vivo" (Borboleta 01, 72).

“-Olha, envelhecer... a gente vai envelhecendo e não está... e não vai sentindo sabe? Quando chega a certas idades, como eu tenho já 83 anos, aí que a gente vai sentir a junta mais dura, os ossos pesados, sabe, então a gente...eu mesmo dá trabalho prá mim calçar meia, prá mim me vestir não, mas prá calçar meia me dá um trabalho só se você vendo! E "marrá” o cadarço do tênis também, me dá trabalho, e o quê eu sinto é isso..." (Borboleta 13, 83).

"Tem um item desse trabalho que você está fazendo que eu não gosto: quando a pessoa diz a melhor idade. Porquê como que pode ser a melhor idade quando você se olha diante de um espelho e vê (pausa)...o cansaço no teu rosto? Você ser plenamente uma coisa e querer fazer e não conseguir mais, e não tem condições físicas, mentais, espirituais prá fazer um trabalho?"(Borboleta 14, 66).

A capacidade funcional (como capacidade ventilatória, força muscular e débito cardíaco) aumenta durante a infância e atinge seu máximo nos primeiros anos da vida adulta, entrando em declínio em seguida. A velocidade do declínio, no entanto, é fortemente determinada por fatores relacionados ao estilo de vida na vida adulta - como, por exemplo, tabagismo, consumo de álcool, nível de atividade física e dieta alimentar - assim como por fatores externos e ambientais. O declínio pode ser tão acentuado a ponto de resultar em uma deficiência prematura. Contudo, a aceleração no declínio pode sofrer influências e ser 
reversível em qualquer idade, por meio de medidas individuais e públicas (OMS, 2005, p. $15)$.

Para Debert (1997), a representação da velhice como um processo contínuo de perdas, associado ao abandono, desprezo e ausência de papéis sociais, foi responsável por uma série de estereótipos negativos em relação aos velhos, mas ajudou também a legitimar um conjunto de direitos sociais, entre eles, o da universalização da aposentadoria.

Beauvoir (1990) refere que, se a saúde permanece boa, a pessoa consegue compensar as capacidades perdidas até uma idade avançada.

Percebi expressões de revolta e protesto quanto à determinadas denominações, pois essas pessoas estão em busca de individualidade para não se tornarem "velhos" sem identidade, uma classe impessoal:

“...esse negócio de melhor idade... eu acho que é careta, sabe, no meu ponto de vista, porquê não é fácil a gente se olhar no espelho e ver já o peso da idade, de querer fazer, ficar dependendo. Eu ainda não "tô" dependendo, eu sou muito auto-suficiente ainda, com 66 anos, mas tem pessoas até com menos idade do que eu que depende totalmente das pessoas. Isso é horrível!" (Borboleta 14, 66)

\section{FALANDO SOBRE A FINITUDE}

Apesar da consciência das modificações e limitações advindas do avançar do tempo, foram poucas as referências quanto à certeza da finitude da vida humana. Apenas em dois entrevistados encontramos referência à morte, mesmo assim de maneira geral e impessoal.

“...ter uma boa experiência, no fato da nossa pouca existência..." (Sabiá, 69) 
"Tudo que nasce, morre, se não vai de pequeno, de velho não escapa" (Pardal, 76).

Outros depoimentos mencionam o tema, referindo-se às pessoas próximas que morreram:

“...porque muitos, que nem meu pai e minha mãe foram novo, né, e eu, com 72 anos, graças a Deus, "tô" feliz de ter chegado até agora" (Borboleta 01, 72).

“... a perda do meu marido, a doença dele que foi muito triste, muito, assim, muito desgastante também, né, me deixou assim muito abalada. Já fazem 4, já vai fazer 5 anos agora que ele faleceu, ai depois duns 3 anos do falecimento....aquilo ali já foi passando, já (pausa e emoção)" (Mariposa 05, 73).

Heidegger aborda o tema da morte caracterizando, como possibilidade ímpar do ser humano, o fato de ser um "ser-para-morte", salientando que a morte dos outros é mais penetrante por ser "objetivamente" acessível. Ou seja, reconhecemos que a morte é um fato natural e inevitável, porém, não conseguimos imaginar nossa própria morte e nem escolhemos como ou quando vamos morrer.

A morte sempre ocorre com os outros, pois a mortalidade e a morte só são reconhecidas por aqueles que permanecem vivos. Para Heidegger, a dificuldade das pessoas em falar da sua finitude está no fato de que, para a maioria delas, morrer significa sair do mundo, não ser mais "presença”, perder o ser-no-mundo.

As pessoas caracterizam a morte como uma grande perda, não para quem morre, mas para os que ficam. Pela morte dos outros, ela vem ao nosso encontro como algo conhecido, que ocorre no mundo, fato cotidiano, porém impessoal. "O discurso pronunciado ou, em algumas vezes, "difuso" sobre a morte diz o seguinte: algum dia, por fim, também se morre, mas, de imediato, não se é atingido pela morte” (HEIDEGGER, 2005, parte II, p. 35). 
O morrer, para Heidegger, necessita ser visto como um fenômeno existencial que completa o curso do ser-no-mundo. No sentido mais amplo, a morte é um fenômeno da vida. Apesar dos avanços na prevenção e no tratamento de doenças, todos sabem que vão morrer um dia. Sejam ricos, pobres, homens, mulheres, negros, brancos, jovens, velhos, religiosos ou ateus. Esta é a grande angústia existencial do homem.

Por mais que se relute em pensar sobre isso, uma certeza permanece: a morte é inevitável. A atitude humana diante da morte tem variado com o tempo e nas diferentes culturas. A perspectiva que cada um de nós tem é influenciada de modo amplo pela sociedade em seus aspectos religiosos, antropológicos, filosóficos, morais e científicos. Mas este confronto é ainda mais difícil para os idosos. Afinal, trata-se de uma questão estatística e de lógica, embora um tanto amarga. Aliada às dificuldades naturais dessa fase da vida, somase mais uma: como conviver com a proximidade da morte?

Döppenschmitt (2005) acredita que são os velhos que talvez mais pensem sobre a morte, pois, por estarem "naturalmente" mais próximos dela, a percebam como um ponto final no tempo de envelhecer.

No entanto, Bosi (1994) relata que, com as mudanças na sociedade burguesa, a morte e seus rituais foram sendo expulsos da percepção dos vivos, passando a ser vista como um fim e algo a ser evitado.

Entretanto, Boemer, Zanetti; Valle (1998) realizaram uma investigação envolvendo pessoas na faixa etária compreendida entre 60 e 87 anos, em três tipos de instituições (hospital geral, asilo e Serviço Social do Comércio/SESC - Escola da Terceira Idade), em um município do interior paulista. Analisaram os depoimentos desses idosos com vistas a compreender se a idéia da morte estava presente e se de forma clara ou velada. O estudo mostrou “...que a convivência com a idéia de morte ocorre com maior intensidade nas situações em que o idoso se vê desprovido de convivência familiar, de objetivos ainda que de 
curto prazo, de atividades, de compromissos" (BOEMER; ZANETTI; VALLE, 1998). Concluíram, então, que o bom desenvolvimento psicológico da velhice deve incluir uma boa relação com a perspectiva da morte. A própria dificuldade da sociedade em lidar com o idoso e aceitar suas limitações ocorre, em parte, pela suposta proximidade da morte.

\section{VIVENDO A ESPIRITUALIDADE}

Se por um lado a finitude é evitada, a manifestação da religiosidade/espiritualidade emerge nas expressões de gratidão a Deus pelos anos já vividos, pela família, pelos recursos materiais adquiridos e na manifestação de atividades religiosas:

"Graças a Deus, minha vida tá sendo maravilhosa! ...com 72 anos, Graças a Deus, tô feliz de ter chegado até agora" (Borboleta 01, 72).

“...tá tudo muito bem, então eu só tenho a agradecer a Deus..." (Borboleta 06, 65).

“Eu não sinto canseira, vou prá igreja, toda primeira semana do mês nós temos oração toda noite, eu consigo ir quase todas as noites e num tenho problema..." (Mariposa 05, 73).

"Eu fui MUITO maltratado, muito mesmo, inclusive eu achei que a minha vida não ia "arcançar" 40 anos, Graças a Deus tô com 72 anos, 71 e tô aqui" (João de Barro, 71).

"Graças a Deus tô muito bem. Me sinto bem, né. Num tô sentido mais indisposto, só sinto alegria e boa vida pra todos, né" (Colibri, \pm 78$)$.

O Censo Demográfico (2000) mostra que a diversidade religiosa brasileira tem crescido muito nas últimas décadas e as informações censitárias permitiram identificar 
também a maior pluralidade religiosa no Brasil. As grandes tendências reveladas, dentre outros aspectos, estão na variedade de religiões concentradas na área urbana do País, que é crescente; no fato das mulheres serem maioria na declaração das religiões e no encontro de um excedente de homens no grupo dos sem religião.

O Brasil continua sendo mais católico apostólico romano, porém com um ritmo de crescimento pequeno. A segunda maior proporção de pessoas religiosas corresponde aos evangélicos, com marcante crescimento dos pentecostais (IBGE, 2000, p. 49). Os idosos são mais religiosos e por isso, na medida em que a idade aumenta, observa-se uma maior proporção dos mesmos tanto nos católicos apostólicos romanos, quanto nas outras religiões (IBGE, 2000, p. 53).

Para Freire Jr e Tavares (2004), é inegável o papel desempenhado pela religião no enfrentamento das exigências da velhice, facilitando a aceitação das perdas, sendo, por isso, um dos recursos utilizados em situações difíceis. O idoso percebe-se neste mundo como um ser privilegiado em razão da longevidade com a qual é agraciado. A certeza da presença de Deus ajuda os idosos a prosseguirem suas vidas com mais perseverança (FRUMI; CELICH, 2006).

Silva e Günther (2000) também referem que as mulheres e os mais idosos participam mais de atividades religiosas, sendo estas as principais atividades sociais desenvolvidas pelas idosas viúvas.

Para além da religiosidade, está a espiritualidade, conforme referem Pessini e Bertachini (2006, p. 380/381), pois "espiritualidade" é um termo muito mais amplo que "religião", sendo definida como "uma tendência inata em direção a Deus ou a uma força superior." A espiritualidade diz respeito a tudo que envolve a existência de uma pessoa, como auto-transcedência, relacionamentos, amor, desejo, criatividade, altruísmo, autosacrifício, fé e crença (id, p. 384). 
Colpo (s/d, p. 7) lembra que "o homem é um ser transcendente implicado a uma espiritualidade e a um projeto de comunhão com tudo.”

\section{CONVIVENDO COM A FAMÍLIA}

Compreendi que a convivência com seus pares e o relacionamento intergeracional é fundamental para uma velhice saudável, bem como a proximidade e a aceitação no núcleo familiar, como revelam os depoimentos:

“...tenho minha família que mora perto, meus filhos sempre "tá" lá em casa... moro sozinho, mas o pessoal meu "tá" tudo junto comigo" (Colibri, \pm 78 , desquitado, 09 filhos).

"Nóis vivemos todos em paz, todos os filhos reúnem em casa, são maravilhosos...e a gente tem paz com todos" (Mariposa 05, 73, viúva, 10 filhos).

"Ter um bom relacionamento familiar...um bom relacionamento social entre as pessoas..." (Sabiá, 69, divorciado, 02 filhos).

“...tendo paz em casa, como graças a Deus eu tenho, sou muito bem com meus filhos, com meus netos, então eu me dou muito bem, eu acho que chegá essa idade é uma ...uma beleza!" (Mariposa 12, 74, viúva, 02 filhos).

Segundo Zimerman (2005), a palavra convivência vem do latim: cum (com) e vivere (viver) e significa estimulação do pensar, do dar, do trocar, do reformular e principalmente do aprender. Para Leite e cols (2002), uma das formas de inserção do idoso na sociedade é por meio da formação de grupos de convivência, nos quais a pessoa idosa encontra espaço para colocar-se e/ou desenvolver atividades. 
Ferrigno (2006) alerta que as gerações vivem em espaços segmentados na sociedade atual, sendo exceção o contexto familiar, onde os encontros entre gerações ocorrem com maior freqüência. Cita ainda que os centros de convivência, de arte e de cultura também são ambientes estimuladores e propagadores das relações intergeracionais.

Mendes e cols. (2005) falam da importância fundamental da família na vida das pessoas, ainda que existam dificuldades para aceitar e entender o envelhecimento de algum de seus membros. Segundo estas autoras:

O ambiente familiar pode determinar as características e o comportamento do idoso. Assim, na família suficientemente sadia, onde predomina uma atmosfera saudável e harmoniosa entre as pessoas, há possibilidade de crescimento de todos, incluindo o idoso, pois todos possuem funções, papéis, lugares e posições e as diferenças da cada um são respeitadas e levadas em consideração (MENDES e cols., 2005, p. 425).

O inverso também é verdadeiro, pois, nas famílias onde há desarmonia e falta de respeito, o relacionamento é frustrante, gerando pessoas deprimidas e agressivas, podendo levar o idoso a tornar-se isolado socialmente, com medo de cometer erros e ser punido. "Reconhece-se que para cada família o envelhecimento assume diferentes valores que, dentro de suas peculiaridades, pode apresentar tanto aspectos de satisfação como de pesadelo" (MENDES e cols., 2005, p.425).

Percebi a valorização dessas pessoas no que se refere ao ambiente familiar, pois os depoimentos ressaltam, especialmente, a proximidade dos filhos e netos e a harmonia dessa convivência. Assim, posso dizer que a família influencia significativamente a vida desses idosos, proporcionando segurança emocional que conduz a uma velhice satisfatória.

Segundo Debert (1997), a tendência é que haja uma inversão na representação da velhice como um processo de perdas e atribuição de novos significados a este momento da vida, que passa a ser tratado como privilegiado para novas conquistas. Os mais velhos, com as experiências vividas e os saberes acumulados, buscam novas oportunidades e estabelecem relações mais profícuas com o mundo dos mais jovens. 
Para Martin Heidegger (2005, parte I, p.170), na base da compreensão do ser-aí, está o fato de que o mundo é sempre compartilhado com os outros. O mundo do ser-aí é mundo compartilhado. Para o filósofo, nossa existência só tem sentido na presença do outro, sendo que é próprio da condição humana viver junto aos outros, numa rede de relações significativas.

O "eu" nunca está só em sua experiência de Dasein; o encontro com outros é um elemento essencial e integral nas realizações recíprocas do ser e do mundo. "Compreender a presença de outros é existir." (STEINER, 1978, p. 79)

\section{SENDO PROJETO}

A facticidade ${ }^{2}$ do envelhecimento surge neste depoimento, mas vem acompanhada da possibilidade de ainda ser:

“...eu ainda tenho muita coisa ainda pra dá dentro de mim, mas enquanto eu tiver força, porque quando eu parar mesmo que não puder mais..., a velhice eu não posso impedi, né, ela tá chegando mas que eu não gosto eu não gosto não...(risos)" (BORBOLETA 14 66 anos).

Para existir, o homem projeta sua vida e procura agir no campo de suas possibilidades. Assim, move uma busca permanente para realizar aquilo que ainda não é. Em outras palavras, existir é construir um projeto; a existência do homem pode projetar e ser existência histórica em devir. (MACHADO DE OLIVEIRA, s/d).

Ser projeto é poder - ser e somente como poder-ser é que faz sentido considerar que ser é ter que ser (CÔRREA, 2000, p. 117). O projeto de vida do homem tem origem no seu passado (em suas experiências) e continuam para o futuro, o qual o homem não pode

\footnotetext{
${ }^{2}$ Facticidade refere-se à condição em que o ser-aí é lançado num 'mundo' já dado, pronto, interpretado, com seus códigos, leis, modos de ser, num momento histórico (COLPO, s/d, p. 19).
} 
controlar e onde esse projeto será sempre incompleto, limitado pela morte que não pode evitar (COBRA, 2001).

Na perspectiva de que o ser-aí, segundo Heidegger, existe numa temporalidade primordialmente futura, marcada por uma finitude (ser-para-a-morte), ele se projeta em possibilidades, existe antecipando-se em relação às suas possibilidades de vir-a-ser, quer sejam elas ilusórias, fantasiosas, impróprias ou próprias (COLPO, s/d).

Admitindo que são ou serão velhas, as pessoas que entrevistei assumem seu ser e mostram-se em constante abertura para vir-a-ser, descobrindo novos caminhos, sentidos e emoções, sendo possibilidades.

Apreendi que as pessoas idosas acreditam que há muito para ser vivido neste fase da vida, pensam no futuro, em novas perspectivas. Guerreiro e Rodrigues (1999) referem que o engajamento social representa um aspecto diferencial no rumo de uma história de vida. Os sentimentos de utilidade, de identificação com os anseios e valores do grupo familiar e /ou social, de inserção e realização intra e interpessoal favorecem a vivência de um estado de plenitude e bem-estar que possibilita à pessoa uma reafirmação em seu sentido existencial, ajudando-a a perceber seu futuro como uma história em aberto, em construção, sendo projeto.

Forghieri (2004) diz que, ao atribuirem significados à sua vida, as pessoas dão sentido à sua existência. Ela vivem num certo espaço e tempo determinados, mas os vivenciam com uma amplitude que ultrapassa estas dimensões objetivas, pois conseguem transcender a situação imediata; seu existir abrange não apenas aquilo que estão vivendo em dado instante, mas, também, as múltiplas possibilidades às quais encontram-se abertas à sua existência.

Ressalta que:

O homem dispõe em sua existência de uma ampla gama de possibilidades para escolher suas relações com o mundo; o ser-simesmo é esta possibilidade de se perceber, abrindo caminho entre essas inúmeras e variadas possibilidades (FORGHIERI, 2004, p. 33). 
A autora continua refletindo sobre a abertura para as possibilidades, referindo-se às dificuldades e paradoxos encontrados no existir humano. No envelhecer, concretamente falando, ao mesmo tempo em que as pessoas podem viver mais plenamente, também estão mais próximas de morrer.

O homem, como ser-no-mundo, é projeto, mas é projeto já projetado e projetado como ser-para-a morte (STEIN, 1988).

Jardim, Medeiros e Brito (2006) referem estudos realizados sobre a representação da velhice em que seu estigma negativo advém sempre da visão do outro; o próprio idoso vê o processo de envelhecimento como um tempo para a construção de algo novo. A pessoa idosa reconhece o que há de importante no envelhecer e procura desfrutar da melhor maneira possível e, mesmo com algumas limitações, consegue ver a velhice com alegria.

Assim, a manutenção da curiosidade, da alegria interior, do interesse e da paixão pela vida pode contribuir em muito para um envelhecimento bem - sucedido (GUERREIRO; RODRIGUES, 1999). 


\section{Reflexões sobre o des-velado}

“Há uma experiência que só pertence àqueles que estão velhos: é a da própria velhice."

(Beauvoir, 1990, p. 470) 
$A$

o habitar o mundo dos centros de convivência pude conviver com pessoas receptivas, alegres, que mostravam amizade, união e prazer de estarem ali. No convívio diário falavam sobre as diferenças na situação das mulheres, no passado e no presente; relembravam histórias da própria vida e da dos pais; comentavam sobre os relacionamentos conjugais, bem ou mal sucedidos; os problemas de saúde, financeiros e da "idade".

Aos poucos, fui percebendo que a velhice é uma vivência tão pessoal que só pode expressar esta experiência quem chega até as fases mais avançadas da vida. Os aspectos físicos, biológicos, psicológicos, sociais podem ser comuns, plurais, mas o existir é particular, singular e tão diferenciado como cada rosto que observei.

Compreendo que, para essas pessoas, não há um processo de envelhecimento, mas a continuidade de um viver. Elas não estão envelhecendo, estão vivendo um momento de suas vidas. Não há uma velhice, mas diversidades possíveis de se viver este momento da existência. Para Zimerman (2005), o velho continua sendo a mesma pessoa que sempre foi.

Apreendi que as principais preocupações das pessoas entrevistadas são:

- mostrarem que não perdem sua identidade por ficarem velhas, e às vezes, apesar da idade cronológica, não se sentem envelhecidas;

- esperam o reconhecimento como cidadãos,

- expressam que ter saúde é essencial e lhes possibilita manter autonomia sobre suas vidas;

- enfatizam a importância do apoio, da convivência e do cuidado na família;

- valorizam sua independência financeira;

- evitam falar sobre a finitude humana. 
Refletindo sobre estas descobertas, penso no tempo, tempo vivido e tempo marcado pelo relógio, no calendário, nos anos, nas horas. Os gregos tinham duas palavras para o tempo: Chronos e Kairós. Enquanto a primeira refere-se ao tempo cronológico, sequencial, mensurável, tempo decorrido, esse último é um momento indeterminado no tempo em que algo especial acontece; é o tempo em relação aos valores, à qualidade, é o tempo vivido, que não se pode medir.

A palavra é usada também em teologia para descrever a forma qualitativa do tempo, o "tempo de Deus", enquanto Chronos é de natureza quantitativa, o "tempo dos homens". (http://pt.wikipedia.org/wiki/Kairos; http://www.rh.com.br/ler.php?cod=4243)

Kairós, que difere do tempo objetivo da produção (Chronos), diz respeitoà idéia de manifestação da verdade viva. Heidegger resgatou este sentido de verdade existencial como Aletheia, manifestação do ser em seu desvelamento, sua descoberta. Transcendendo Chronos, o tempo objetivado da modernidade, o Kairós é o tempo subjetivo da experiência do fluir da vida. É também o tempo da experiência compartilhada com o outro, tempo favorável, oportuno, que cria os significados da vida (BITTENCOURT, 2005).

Silva (2005) também chama atenção para o fato de que as idades biológica, social e psicológica não coincidem, necessariamente, com a idade cronológica. Desde que não haja comprometimento biológico por alguma doença, o potencial psicológico não cessa na velhice.

Duarte diz que:

O declive biológico é real e em certa medida irreversível, mas não existe momento algum em que o crescimento psicológico do indivíduo deve cessar. $\mathrm{O}$ desenvolvimento psicológico pode conservar uma real independência com respeito a irreversibilidade do processo biológico. $\mathrm{O}$ fator biológico terá maior ou menor peso conforme seja a personalidade do indivíduo (1999, p. 43).

Chegar até determinada idade vem no "continum” da vida. Não são etapas separadas, independentes, são continuações das histórias de vida. E, mais do que isto, a forma como vivem a velhice interliga-se às experiências pessoais e do grupo social do qual fazem parte. 
As diversas experiências de vida vão construindo muitas velhices, diferentes trajetórias de envelhecimento, por caminhos distintos, estabelecendo sempre diferenças entre o passado e presente.

Sob esta perspectiva, acredito que possa ter encontrado algumas respostas para minhas inquietudes iniciais: como manter a independência e a vida ativa com o envelhecimento?; como fortalecer políticas de prevenção e promoção da saúde, especialmente aquelas voltadas para os idosos?; como manter elou melhorar a qualidade de vida com o envelhecimento?; o que é isto, o envelhecer?

Para Bittencourt (2005), no plano do sujeito, o conceito de horizonte existencial sugere a interpenetração do passado, do presente e do futuro, de modo que a significação do passado e do presente pode ser modificada pelo sentido da trajetória do Ser. A esfera do futuro, por outro lado, confere à existência uma angustiante ambigüidade, já que o futuro é o lugar dos sonhos, dos projetos, mas também da morte.

Segundo Minayo e Coimbra Jr. (2002) o envelhecimento não é um processo homogêneo, pois cada pessoa vivencia a velhice de uma forma, considerando sua história particular e todos os aspectos estruturais (classe, gênero e etnia) a ela relacionados, como saúde, educação e condições econômicas.

Duarte (1999) reafirma a idéia da velhice como um processo marcado e modelado pelo modo como cada pessoa capta e vivencia os acontecimentos surgidos em sua vida. Enfatiza a contribuição dos fatores sociais na diferenciação da biografia de cada pessoa, ressaltando que não se pode atribuir somente à idade qualquer tipo de alteração.

Fogaça (1999) diz que o sentido atribuído à existência e os valores que lhe são dados definem o sentido e o valor da velhice. Dependendo do modo que a sociedade trata o velho, será o seu valor nessa sociedade. A autora acredita que as pessoas, na medida em que conhecem mais a respeito do envelhecer, mais conseguirão enfrentá-lo como um processo 
natural de todos os seres. Poderão lhe dar o devido valor e reconhecer sua importância, tão esquecida e tão deturpada, do idoso para com tudo e com todos. Ele é parte da história, mesmo sem ter uma consciência precisa desse pertencimento. (i.d., p. 203)

Debert (2000) reconhece que a sociedade brasileira é hoje muito mais sensível e tem aberto espaços para que experiências inovadoras de envelhecimento possam ser vividas, mas que o sucesso dessas experiências não pode dissolver os dramas da velhice no descuido de alguns que não puderam experienciar esses novos espaços, adotando estilos de vida e formas de consumo inadequadas. Diz ainda que o reconhecimento da pluralidade de experiências de envelhecimento não implica supor que a dependência não é condição natural dos que ficam velhos (Debert, 1997).

O envelhecimento funcional é inexorável e universal e, à medida que os anos passam, surge a necessidade de alguma ajuda para desempenhar as atividades de vida diária (PASCHOAL, 2006).

O homem não pode ser considerado como algo homogêneo e uniforme, o que torna cada um de nós um ser complexo e particular, plural e singular, num momento dialético existencial. A realidade precisa ser compreendida em suas várias possibilidades (BOARETTO, 2005, p. 53).

Minayo e Coimbra Jr. (2002) referem que o tema envelhecimento é complexo, como complexos são todos os processos vitais humanos, mas que não podemos associar o envelhecer com doença, privação, dependência, tristeza e frustração. O envelhecimento deve ser visto como um tempo produtivo específico da vida, emocional, intelectual e social, superando os estigmas da discriminação, almejando viver bem, e de modo dinâmico, a velhice.

Na perspectiva existencial, o ser humano vai além da compreensão do Ser, interroga-se sobre si próprio, busca ser plenamente homem. Ele não é acabado como os outros entes, pois quer ultrapassar-se. 
Ser homem é buscar uma explicação, arquitetar a vida individual que é nossa. É através dela que o homem aparece, não como algo que está aí no mundo, (como uma coisa), mas como alguém que pode ser, encontrar-se com os outros homens, tocar a essência do mundo (BEAINI, 1981, p. 31).

Essa autora completa dizendo que “...o des-velamento nunca é total. Em cada desvelamento está contido também um velamento; enquanto revelamos um domínio do ente encobrimos outro. Assim, a verdade mescla-se continuamente de não-verdade" (BEAINI, 1981, p. 50).

Para essas pessoas que entrevistei a velhice está sendo um tempo de descobertas e vivência de novas possibilidades, sem conformismo, com engajamento político social na luta para exercer direitos já assegurados por lei e garantir outros que ainda não estão adquiridos.

Apesar das dificuldades, mostram satisfação com a vida e cada um, a seu modo, busca meios de compensar as perdas, sejam físicas ou sociais. Estão incluídas no grupo “...de indivíduos idosos, relativamente saudáveis e com possibilidades de viverem a velhice de modo ativo e participativo" (NERI, 2003, p. 07).

Concordo com Magro (2003) que considera a vida humana como um processo inacabado e em constante devir, e os idosos não como pessoas acabadas, que já foram, mas como seres que estão sendo. Assim, também concordando com Zimerman (2005), apreendi que é preciso compreender o envelhecimento como um processo gradual, de adaptação às mudanças da vida, que vai, aos poucos, tornando-se realidade.

Esta autora, por meio de sua convivência com pessoas idosas, conclui que:

As pessoas mais otimistas, mesmo quando envelhecem, são mais propensas a verem este tempo com maturidade e aproveitam a liberdade para assumir novas ocupações e até mesmo se liberarem de certas responsabilidades (ZIMERMAN, 2005, p. 25).

No entanto, diz que é preciso fazer planos, ter objetivos de vida, desejar algo, buscar realizações, redescobrir seus gostos, preparar-se internamente para reconhecer suas limitações e suas possibilidades, mas, principalmente, continuar vivendo (ZIMERMAN, 2005). Beauvoir 
(1990) reafirma que o moral e o físico estão estreitamente ligados e que para adaptar-se à velhice, é preciso ter conservado o prazer de viver.

Conforme Paschoal (2006), o grande desafio que a longevidade nos coloca é o de conseguir que os anos vividos a mais, muitos ou poucos, sejam plenos de significado, levando a uma vida digna e respeitosa, que valha a pena ser vivida. A intenção é promover a produtividade dos idosos e ajudá-los a desenvolver seu potencial para que continuem contribuindo de maneira positiva com a sociedade e sejam porta-vozes da experiência (OPS, 1993, p.8).

Se a pessoa é capaz de adaptar-se às mudanças inevitáveis do envelhecimento, do ponto vista social, ela pode viver uma velhice feliz, utilizando sua capacidade de contribuição e crescimento. Portanto, é recomendada a participação da pessoa idosa em atividades de diversos grupos, na medida em que suas condições de saúde permitam (OPS, 1993, p. 9;11).

Silva (2005) afirma que é preciso haver mudança de valores de forma que a imagem negativa que a sociedade propaga dos idosos, de fragilidade e dependência, seja alterada. As pessoas idosas precisam de oportunidades para serem incluídas nas decisões a respeito da sociedade e de sua vida diária; elas não desejam ser excluídas e rotuladas somente como objetos de cuidado.

$\mathrm{Na}$ área de formação profissional, permaneço com o desafio de mudar os preconceitos acerca da velhice e do envelhecimento, o que envolve olhar o idoso como um cidadão, com direitos e deveres quanto aos cuidados de saúde e a um viver condigno. Desfazer o mito de que doença e incapacidade são resultados inevitáveis do envelhecimento e de que velhice e enfermidade são sinônimos; que os idosos são pessoas incapazes, doentes, deficientes, isoladas, intransigentes, incapacitadas para pensar e refletir. Esclarecer que, para um envelhecimento bem-sucedido, é necessária a manutenção da autonomia e independência da pessoa idosa e não somente prevenir o surgimento de doenças. 
Garrido e Menezes (2002) esperam que uma das boas notícias sobre a questão do envelhecimento no Brasil seja o treinamento adequado de um crescente número de profissionais, para que possam lidar com os problemas sociais, econômicos e de saúde que afetam a população idosa e que estejam voltados aos direitos do idoso como pessoa.

Steavenson; Gonçalves; Alvarez (1997) já apontavam os principais desafios na área de formação de recursos humanos voltados para enfermagem geriátrica e gerontológica, enfatizando a necessidade de mudanças curriculares para atualização de conhecimentos e aquisição de habilidades gerais e básicas para cuidar do idoso, tanto na graduação como nos cursos técnicos e auxiliar de enfermagem; o aprofundamento em conhecimentos específicos vindo da especialização e outros níveis de pós-graduação, possibilitando a participação e intervenção no planejamento de políticas, programas e serviços voltados para a população idosa, a nível local, regional e até nacional.

Diogo (2004) cita as recomendações traçadas na Terceira Reunião do Comitê Técnico para a Segunda Assembléia Mundial sobre o Envelhecimento (ocorrida em Madrid, de 8 a 12 de abril de 2002), destacando: a expansão da educação profissional em gerontologia e geriatria; a inclusão de treinamento multidisciplinar; a formação básica e especializada sobre a saúde do idoso; a promoção de programas de educação contínua em saúde, bem-estar e cuidado de pessoas idosas para profissionais da área da saúde, assistência social e cuidadores; o estímulo para o aumento do interesse dos estudantes na área e a promoção de programas de treinamento em gerontologia e geriatria, em países em desenvolvimento, por meio da cooperação bilateral e multilateral internacional.

Lembra ainda que as escolas de enfermagem do Brasil apresentam escasso número de docentes envolvidos em programas de mestrado ou doutorado, que estejam desenvolvendo pesquisas ou estudando enfermagem gerontológica. A maioria dos professores dos cursos de 
graduação em Enfermagem ministra conteúdos sobre esse tema utilizando sua experiência ou conhecimentos ou por meio de auto-estudo e educação contínua.

Duarte (1994) reforça que o enfermeiro tem um espaço profissional importante, na área de saúde pública, para atuar com idosos, com autonomia, sistematizando um corpo de conhecimentos específicos de sua área de competência, usando sua experiência e criatividade.

Concordo com Steavenson; Gonçalves; Alvarez (1997) no que diz respeito à participação dos profissionais como facilitadores no processo da reconquista e exercício da cidadania por parte de uma grande parcela da população idosa marginalizada e empobrecida econômica, social e politicamente; o desafio vai além, pois requer que muitos profissionais retomem o exercício do seu poder político em nível pessoal, e até mesmo, enquanto membro de uma categoria profissional.

Nesse sentido, retomo o proposto por Ayres (2003-2004), quando diz que filosofia e construção de políticas necessitam estar interligadas, de forma que uma desconstrução dessas políticas possa ser efetuada com vistas à sua reconstrução, embasada em fundamentos e princípios filosóficos que contemplem, sobretudo, a essência da pessoa a ser cuidada.

A pessoa, em seu sendo-envelhecendo, como abordado no presente estudo, pode desencadear discussões sobre as políticas que se proponham dela cuidar nesse momento, que vivencia, nesse tempo do curso da vida, reavaliando as dimensões técnico, científica e humana.

A convivência com as pessoas idosas, sujeitos deste estudo, mostrou-me que existência e vida não são sinônimos, porque somente o homem tem existência; somente o homem pode ser ansioso e alienado e somente o homem pode se questionar: "quem sou eu?". A questão da existência sempre só poderá ser esclarecida pelo existir (HEIDEGGER, 2005, parte I, p. 39). 
Dos depoimentos dos entrevistados, captei a essência do envelhecer, com destaque para a manutenção da saúde, a convivência familiar e social, a experiência advinda do transcorrer da vida, tendo esta sido fácil ou difícil, e disposição para continuar vivendo e aprendendo.

Construí, através dos depoimentos, uma imagem pessoal do ser idoso vivendo e envelhecendo:

"Olha, eu...eu acho que chega nessa idade o principal é a pessoa ter saúde, né, ter o bem estar, viver bem com a família, viver em paz consigo mesma e eu acho que isso é o mais importante, né, acredito que a saúde é uma coisa muito importante, é bom tendo saúde...saúde, paz em casa como Graças a Deus eu tenho, sou muito bem com meus filhos, com meus netos então eu me dou muito bem eu acho que chega essa idade é uma...uma beleza. Porque minha velhice "tá" maravilhosa eu "tô" com saúde minha pressão é boa, não tenho diabetes, não tenho outras doenças nenhuma. Graças a Deus, minha vida "tá" sendo maravilhosa! Sempre vivo muito também satisfeito, né, por causa dos amigos que a gente tem (pausa) e sempre, nun..nun...nunca fiquei doente quase. Sobre o meu envelhecimento, eu sou muito feliz, muito Graças a Deus, porque o quê eu tinha de passar, eu passei, que é problema de saúde sério, tive várias "veiz”, tive na "bera” da sepultura, mas Graças a Deus, eu sai dessa, então eu sou uma pessoa feliz, vivo muito bem com a minha família, não tenho, "probrema" nenhum com meus vizinho, com todo mundo, eu combino com todo mundo então, prá mim tá sendo MUITO bom, melhor do que eu esperava, eu tinha muito medo de ficá velho (pausa), assim doente, sem ter alguém prá cuida, né, porque isso é muito difícil, mas Graças a Deus, eu acho que eu não vô tê esse problema. Pra mim tá sendo ótimo, né. Tô... tô bem melhor agora do quê quando eu era mais novo, sabe! Porque agora pelo menos eu já sinto realizado já..., E SOU FELIZ E MUITO MUITO MUITO FELIZ, porque na verdade eu não sinto que eu estou envelhecendo, eu sinto que eu estou vivendo e adquirindo cada vez mais experiência. Envelhecer é o seguinte: a pessoa nunca deve ficar parada, ele tem 
que ser alegre, certo? Ser uma pessoa... brincar com outros, não ficar pensando maldade na cabeça. Não pode ficar só dentro de casa, a mente tem que ser ocupada."

Pude perceber que as pessoas entrevistadas, assim como detectaram Santana e Santos (2005), querem ficar idosas, ou seja, envelhecer com saúde e não ficarem velhas, doentes e inúteis e indesejadas.

A vida é um eterno aprendizado. Sempre precisamos aprender com os outros, observar pessoas com ricas histórias para escrevermos nossa própria história (CURY, 2004, p. 22). 
7. Sentido e Significados do Envelhecimento para a Prática de Enfermagem

"Ninguém repete o envelhecimento do outro" (PASCHOAL, 2006, p. 330). 
$N$

ão pretendo aqui discutir a especificidade da assistência de enfermagem gerontogeriátrica, mas sim pontuar que contribuições este estudo pode oferecer para as diversas áreas de atendimento da enfermagem que envolvam pessoas idosas, uma vez que a visão é a partir da pessoa que está em processo de envelhecimento.

Ao citar vários autores que discutem a especificidade da atenção em enfermagem, aproprio-me de suas idéias para explicitar o que é a Enfermagem, enquanto ciência e arte, e qual é seu objeto de atuação.

Tradicionalmente, a Enfermagem tem sido considerada como a arte de cuidar dos doentes, razão pela qual a maior parte de suas ações tem sido direcionada para recuperar a saúde dos pacientes; mais recentemente, a ênfase foi redirecionada ao planejamento e implantação de programas destinados à atenção das necessidades da saúde da população, especialmente promoção e prevenção.

Neste mesmo sentido, a atenção de enfermagem aos idosos deve transformar-se de uma ação eminentemente curativa e paliativa, para outra de caráter integral, na qual a promoção e desenvolvimento da saúde constituam-se em eixo fundamental (OPS, 1993, p.5).

Erdmann e cols (2006) enfatizam que o sujeito do cuidado de enfermagem é a pessoa e que algumas diretrizes que orientam a dimensão ética deste cuidado são: o respeito à sua dignidade, o valor de sua vida, os direitos que possui como ser humano, como o direito à saúde, ao bem estar, à segurança, à paz, à educação, ao trabalho, ao lazer, entre outros. As autoras lembram ainda a complexidade do trabalho da enfermagem, especialmente do enfermeiro, pois envolve o cuidar, o gerenciar e o educar. 
Carvalho (2003, p.669) diz que a Enfermagem é:

Uma arte que dispõe de um saber profissional e de conhecimentos específicos sobre os cuidados prestados no âmbito do que-fazer da enfermeira. Arte de apoiar os clientes no alcance de condições compatíveis com um nível ótimo de saúde, ou para que possam exigir seus direitos de cidadania no que tange às crises na saúde e aos riscos das enfermidades. Arte de cuidar que, no âmbito da prática assistencial, constitui o eixo de sustentação do papel profissional e da responsabilidade social da enfermeira.

Concordo com Waldow, Lopes; Meyer (1995, p. 8) a respeito do cuidado como essência, razão existencial da enfermagem e de que, nesta área, o cuidar/cuidado é genuíno e peculiar. Enfatiza que o cuidado humano é “...uma característica única e essencial da prática da enfermagem.”. Cuidar é resposta a alguém ou a alguma coisa a quem ou à qual se atribui alguma importância e que representa um valor.

O cuidado humano, segundo a mesma autora, vem permeado por valores que priorizam a paz, a liberdade, o respeito e o amor. Deve harmonizar aspectos como raciocínio lógico + emoção + sentimento + intuição, elaborando uma forma ímpar de conceber a realidade.

Nas sociedades em que, pelas tensões e crises contemporâneas, sentimentos expressos de compaixão, gratidão, tolerância, doçura, humor, perdem-se e esvaziam-se, o cuidar/cuidado deve ser visto como uma característica humana, um imperativo moral, afeto, interação inter-pessoal e não apenas como uma intervenção.

Cuidar "consiste de esforços transpessoais de ser humano para ser humano, no sentido de proteger, promover e preservar humanidade, ajudando pessoas a encontrar significados na doença, sofrimento e dor, bem como na existência. É ainda ajudar a outra pessoa a obter autoconhecimento, controle e autocura...." (WALDOW; LOPES; MEYER 1995, p. 16). A enfermeira é co-participante, na equipe multiprofissional, num processo de cuidar que oferece doação, respeito e dignidade ao ser humano, com ações complementares e não competitivas. 
Além disso, devemos incluir como cosntituintes do cuidado: paciência, honestidade, humildade, esperança e coragem. Para Waldow, Lopes e Meyer (1995, p. 15), na Enfermagem o processo de cuidar/cuidado, deve combinar fatores como:

- Formação de um sistema de valores humanísticos- altruísticos;

- Instilação de fé e esperança;

- Cultivo da sensibilidade para o nosso eu e o dos outros;

- Desenvolvimento de um relacionamento de ajuda- confiança;

- Promoção e aceitação da expressão de sentimentos positivos e negativos;

- Utilização de mecanismos de resolução de problemas;

- Promoção ensino- aprendizado transpessoal;

- Desenvolvimento de meio ambiente de apoio, proteção e ajuda mental, física, social e espiritual;

- Satisfação de necessidades humanas;

- Aceitação de forças espirituais e existenciais.

Desejo, assim, situar a Enfermagem como uma profissão do cuidado, que envolve a atitude de cuidar e que, na relação enfermeiro - pessoa que é cuidada, perpassam os valores pessoais de ambos. As possíveis repercussões desses valores, com reflexos na prática dos enfermeiros, podem ser percebidas no cotidiano, no relacionamento entre clientes e profissionais de enfermagem.

Este relacionamento interliga-se também à subjetividade do profissional que assiste, intervindo no cuidar - no agir humano (BRUM, TOCANTINS e SILVA, 2005). As autoras citam que, por vezes, o profissional de enfermagem encontra-se impregnado de valores negativos em relação à velhice, pois, na sociedade em que vivemos, impera o estereótipo do 
idoso como um ser improdutivo, doente, inválido e ultrapassado, em fase final de sua vida, sem objetivos e esperanças. Isso se reflete em sua prática profissional, no seu modo de cuidar.

Acredito na prática de enfermagem com abordagem humanística, que priorize e contribua para um cuidar que atenda às necessidades da pessoa idosa, valorize sua vivência, suas crenças e seus valores. Assim, o cuidar deve atender às necessidades físicas e não físicas do indivíduo, englobando ambiente-cliente-família-profissional, visando contemplar a vida (BRUM, TOCANTINS e SILVA, 2005).

A enfermagem pode ser vista como fonte de recursos para os idosos a desenvolverem suas capacidades e potencialidades, reconhecendo suas experiências, sabedoria, contribuições e valores como seres humanos (OPS, 1993).

A ação do cuidar pelo enfermeiro necessita valorizar o ser humano em sua existência independente da expectativa de recuperação ou possibilidade de viver e sim pelas necessidades de cuidados, seja em nível primário, secundário ou terciário. Acredito que o desenvolvimento da ação de cuidar da pessoa idosa deva ser pautado no estabelecimento de uma relação social, na qual existem sujeitos interagindo, atuando e comunicando-se, numa atmosfera de compreensão. Uma relação social que implica em envolvimento com o outro - o idoso, na qual as experiências do profissional fazem-se presente como atitude em estar com o outro (BRUM, TOCANTINS e SILVA, 2005).

Caldas (2000) refere que a esfera existencial é um importante componente do cuidado e ocorre quando aquele que cuida compreende o mundo subjetivo do paciente, vivencia a união com este e expressa-a de tal forma que a singularidade de cada um emerge, surgindo a dimensão da intersubjetividade, sendo possível respeitar-se a liberdade de ser de cada um. Portanto, o cuidado existencial entre duas pessoas transcende o tempo, o espaço e o cotidiano.

A pessoa idosa e sua família são componentes essenciais no alcance dos objetivos de saúde e na efetividade das ações da enfermagem. Portanto, o progresso e o alcance das metas 
estabelecidas devem ser avaliados de forma conjunta. $\mathrm{O}$ cuidado integral à pessoa idosa inclui envolvê-la ativamente, em conjunto com sua família, em um processo dinâmico e contínuo de seu cuidado, determinando as metas, identificando novas metas, reordenando prioridades e iniciando outras ações (OPS, 1993, p.39).

Da mesma forma que nas diversas ações da enfermeira, as atividades da enfermagem gerontológica são direcionadas para alcançar o nível máximo de saúde das pessoas idosas, sadias ou doentes, mediante uma abordagem holística e interdisciplinar, tanto no âmbito familiar como comunitário e institucional, seja ambulatorial, hospitalar ou de reabilitação (OPS, 1993, p.40).

Não existe uma fórmula para avaliação do idoso; a abordagem deve ser centrada na pessoa, reconhecendo sua singularidade e também a pluralidade deste grupo da população. Não se pode esquecer que os idosos trazem consigo uma história de vida, plena de eventos, de pessoas, de ambientes e de interações que os fazem reagir de uma maneira muito particular (OPS, 1993, p.41).

Caldas (2000) ressalta que é fundamental para a prática da enfermagem gerontogeriátrica que o conceito de "qualidade de vida" assuma destaque muito mais abrangente que o conceito de "cura da doença". O prioritário é promover a saúde do idoso e não se preocupar apenas com o quadro patológico. O cuidar inclui, então, a redução de fatores de risco previsíveis. O objetivo mais importante é buscar o melhor bem-estar possível da pessoa.

Para Silva (2000, p. 88):

Cuidar do outro é, antes de tudo, ajudá-lo cuidar de si. Para tanto, é preciso que, através do diálogo reflexivo, me engaje com o outro no seu processo de vida. Que busque com ele refletir sobre a sua história, fornecendo os instrumentais necessários para que ele possa exercitar a sua capacidade criadora e emancipadora para ser e agir em sociedade. 
Para Lima (2005, p. 71):

Enfermagem é uma ciência humana, de pessoas e de experiências com campo de conhecimento, fundamentações e práticas do cuidar dos seres humanos, que abrangem do estado de saúde aos estados de doença, mediada por transações pessoais, profissionais, científicas, estéticas, éticas e políticas.

Para Erdmann, Ramos; Reibnitz (2006), o trabalho da enfermagem resulta da reunião de pessoas que executam ações, implementam processos em consonância com objetivos e metas comuns, que se movimentam e se transformam.

Minha experiência profissional, como enfermeira assistencial e docente, em Unidades de Internação de Clínica Médica, nas mais diversas especialidades, colocou-me diante de várias situações envolvendo a questão de cuidar da pessoa idosa caracterizada, na perspectiva médica, como portadora de alguma doença crônico- degenerativa, com poucas possibilidades de recuperar o estado de saúde anterior.

Percebi também o distanciamento em relação ao idoso como pessoa. As ações da equipe de enfermagem restringiam-se ao cumprimento das prescrições médicas de enfermagem, quando esta existia, e aos cuidados físicos básicos, como higiene corporal e alimentação. Assim, fui mergulhando em reflexões e questionamentos a respeito da ação de cuidar do idoso, não apenas no ambiente hospitalar, mas também englobando a contribuição da enfermagem ao idoso ativo, independente.

Minha intenção foi apresentar, por meio dos depoimentos, quais sentidos e significados pode ter, para a prática de enfermagem, o desvelamento de como é viver o envelhecer, numa perspectiva fenomenológica.

Ao aproximar-me da vivência do envelhecer pude ressaltar a subjetividade de cada pessoa, fortalecendo o vínculo profissional-usuário, proporcionando acolhimento e oferecendo uma prática de enfermagem voltada às necessidades e às características dessa 
população. A perspectiva é de atuar a partir da visão do idoso como sujeito e não como alguém inútil e dependente, que não consegue falar e agir por si próprio.

Não irei me deter nos aspectos intrínsecos da assistência de enfermagem ao idoso hospitalizado ou doente, pois a ligação que pretendo estabelecer é, como conhecendo o sentir dessas pessoas idosas, posso adequar a assistência prestada e ajudá-las a manter sua identidade e independência.

Remetendo-me a Ferreira e Derntl (2006, p. 447) quando afirmam que "idosos são hospitalizados porque estão doentes, não porque são velhos" e a Duarte e Lebrão (2006, p. 471) quando dizem que o envelhecimento saudável vai além da idade cronológica, é que situo as contribuições deste estudo para assistência de enfermagem em um contexto mais amplo.

Acredito que a análise dos depoimentos possibilita mudanças na visão estereotipada da velhice e reafirma que o conhecimento sobre como cuidar de idosos necessita avançar para além do mundo hospitalar e domiciliar.

Quando falo em sentido, refiro-me à motivação a partir da qual posso construir um novo modo de agir no cuidado às pessoas idosas, sejam doentes ou saudáveis. O significado está na tentativa de transformar a imagem da velhice no contexto do cuidado de enfermagem.

Lembrando Gonçalves e Alvarez (2004, p. 58), espero também ter contribuído para “...estimular o aperfeiçoamento de novos profissionais da enfermagem nessa área de trabalho em franca expansão, face ao aumento da população idosa e de suas crescentes demandas, especialmente na ordem social e sanitária”. 


\section{Algumas considerações sobre Enfermagem Gerontológica}

A Organização Pan-americana de Saúde considera a Enfermagem Gerontológica como sendo:

O estudo científico do cuidado de enfermagem ao idoso, caracterizado como ciência aplicada com o propósito de utilizar os conhecimentos do processo de envelhecimento para o planejamento da assistência de enfermagem e dos serviços que melhor atendam à promoção da saúde, à longevidade, à independência e ao nível mais alto possível de funcionamento da pessoa (OPS, 1993, p.35).

Então, com base nesta definição, somado ao desvelado neste estudo, acredito ter acrescentado fundamentos que auxiliem os profissionais de enfermagem na assistência à pessoa idosa, visando a prevenção de doenças, a promoção, manutenção e restauração da saúde, bem como da dignidade e da independência destas pessoas, até a sua finitude.

Gonçalves e Alvarez (2004, p. 60) citam os objetivos da enfermagem gerontológica, assinalados por Diogo e Duarte (1999), quais sejam:

- assistir integralmente o idoso, a sua família e a comunidade na qual ele estiver inserido, favorecendo a compreensão das mudanças decorrentes do processo de envelhecimento e facilitando as adaptações necessárias ao viver diário;

- promover educação para a vida e a saúde nos níveis primário, secundário e terciário junto à clientela idosa e à sua respectiva família;

- favorecer a participação ativa do idoso e de seus familiares, propiciando que funcionem em bom nível de auto - cuidado e que sejam eles próprios os detentores do poder pessoal para decidirem o melhor para suas vidas, seu bem-estar e qualidade de vida.

Para Duarte e Lebrão (2006), o cuidado gerontológico tem por base a manutenção, no melhor nível possível, da condição funcional dos idosos, ou seja, deve objetivar que o idoso seja capaz, independentemente do número de condições crônicas coexistentes, de manter o 
melhor e maior nível possível de independência e autonomia no desempenho de suas atividades cotidianas.

Diogo (2000) ressalta que a avaliação funcional do idoso faz parte do cuidado de enfermagem, com ênfase na pessoa e nos sistemas de apoio com os quais ela possa contar. Compreende que a enfermeira, inserida numa equipe mutidisciplinar, deve assistir ao idoso de maneira individualizada, levando em consideração as suas limitações físicas, psíquicas e ambientais.

Acredito que ao compreender a vivência do processo de envelhecimento, conforme proposto no presente trabalho, possa facilitar o alcance destes objetivos.

Entendo que, na interação do profissional com a pessoa idosa, temos, de um lado o sujeito idoso, com suas peculiaridades individuais, pertencente a uma família e comunidade, contextualizado em um dado mundo, e, do outro, a enfermeira, com suas características pessoais e de formação profissional, com conhecimentos básicos e às vezes específicos da gerontologia, porém atuando segundo a especificidade do serviço onde trabalha, com suas necessidades, valores e habilidades, com as influências culturais da comunidade a qual pertence.

Steavenson; Gonçalves; Alvarez (1997, p. 38) apresentam o referencial de McConnell (1988) para explicar a prática do cuidado de enfermagem gerontológica, em função de quatro metas a alcançar, ou sejam: promoção da saúde, compensação dos déficits e incapacidades, promoção do conforto e apoio, facilitação do diagnóstico, tratamento, cuidado e conforto. Creio que tais metas correspondem também aos objetivos gerais da assistência de enfermagem.

A ação de cuidar baseia-se na metodologia do processo de enfermagem, adotado, tradicionalmente, como o instrumento para praticar a enfermagem, mas a especificidade está na relação estabelecida com a pessoa idosa, no esforço pela promoção e/ou manutenção de 
comportamentos saudáveis; a busca de compensações devido a perdas e disfunções relacionadas à doenças, assim como a prevenção de deficiências/ disfunções futuras (preveníveis ou adiáveis); a promoção do conforto, apoio e assistência no tratamento e avaliação, para o alcance da melhor qualidade de vida possível.

Penso, então, que para atingir a excelência deste cuidado, devo conhecer de que modo, cada pessoa, em particular, vivencia seu envelhecimento e como se sente a respeito deste envelhecer. A atenção é, assim, individualizada, liberta de esteriótipos ligados a esta população; o cuidado é dirigido à pessoa e não ao seu(s) problema(s), considerando-se todo o seu contexto de vida pessoal, familiar, comunitário e de ambiente físico e social.

No âmbito da promoção da saúde, o cuidado da enfermeira pode ser o de intermediação, de encaminhamento, na tentativa de assegurar a continuidade da atenção à saúde das pessoas, além da educação em saúde e o trabalho interdisciplinar entre a equipe de saúde. Conforme Steavenson; Gonçalves; Alvarez (1997), a atuação da enfermagem requer educação formal e informal, dirigida para pessoas, famílias, grupos, comunidades em geral, com vistas à formação de recursos humanos diversificados na área gerontológica.

As autoras ainda enfatizam o estímulo ao auto-cuidado, com o objetivo de maximizar as potencialidades do ser idoso para o desenvolvimento pleno de seu poder pessoal e político, levando ao exercício de sua autonomia e a um envelhecer com qualidade e bem sucedido.

Acredito que, para assegurar a dimensão humana do cuidado, é imprescindível o respeito à autonomia e à dignidade do outro. Pela cumplicidade e do apoio mútuos, posso conhecer a mim e ao contexto no qual vivo, para, em conjunto com o outro, transformarmos a realidade.

Diante do exposto, concordo com Silva (2000) que o cuidado profissional apresenta-se como uma prática complexa, assim como a natureza do ser, das relações que estabelece e do viver em sociedade. Os valores éticos e políticos, bem como outros valores sociais e de 
cidadania, confluem para os valores profissionais do cuidado, tornando-o essencialmente humano.

Ferreira e Derntl (2006) lembram que o cotidiano do trabalho da enfermagem inclui toda a complexidade dos recursos tecnológicos; as relações com a instituição e as interpessoais com os demais membros da equipe de saúde e com as pessoas sob seus cuidados, seus familiares e a comunidade.

Compreendo que, para uma efetiva assistência de enfermagem, os profissionais precisam estar preparados para atuar nos vários níveis de atenção à saúde, como prevenção e promoção, e não apenas tratar e cuidar de pacientes hospitalizados. Concordo com Oguisso (2000, p. 50) quando afirma que “...o enfermeiro, por sua atitude, precisa transmitir ânimo, coragem e força, e se não for possível a cura, pelo menos, sempre é possível dar mais conforto."

Conforme esta autora, como enfermeiras temos que,

...simultaneamente, assegurar competência técnica no exercício profissional aliado ao espírito humanitário, acrescentando mais calor humano em cada gesto da ação de cuidar, em cada palavra e até mesmo no tom de voz, procurando transmitir através de nossa expressão corporal, aquela tranqüilidade, segurança e afetividade de quem realmente gosta do que faz e faz porque gosta (OGUISSO, 2000, p. 51).

A meu ver, para concretizar tal atuação, é preciso identificar a pessoa idosa como sujeito histórico, levar em consideração sua cultura, sentimentos e questionamentos, sua vivência deste envelhecer e, a partir desse conhecimento, “...instruir as práticas de saúde na perspectiva da promoção da saúde, contribuindo com um aporte concreto e efetivo para reorganização da atenção" (FREIRE JR, TAVARES, 2004- 2005, p.148).

Como diz Erdmann (1997, p. 153), o trabalho de enfermagem na atenção à saúde do idoso deve ser realizado com profissionalismo, responsabilidade, presteza, seriedade, respeito, honestidade e ser tecnicamente correto segundo os valores da profissão. 
É preciso ouvir o idoso e perscrutar seus desejos e necessidades, compreender cada um, individualmente, sem afrontar seus direitos de ser humano. (FERREIRA; DERNTL, 2006)

Segundo Corrêa (2000), a fenomenologia existencial permite que se vislumbre outras possibilidades para além da realidade e, portanto, espero ter contribuído para que o cuidado seja dirigido à pessoa idosa, doente ou saudável, e não para o "doente" idoso ou o "velhinho cheio de energia". 
8. Referências 
ANTONELLI, Marco Antônio Monteiro. Envelhecer: quantidade com qualidade. s/d Disponível em: www.humanus.com.br/notícias.html. Acesso em: 19 junho 2004.

ARAÚJO, Luiz Mário Valença. Envelhecimento bem sucedido. 02/04/2007. Disponível em http://www.unimedfs.com.br/noti1.php?cod_noti=396\&tip_noti=3. Acesso em: 16 abril 2007.

AYRES, José Ricardo de Carvalho Mesquita. Cuidado e reconstrução das práticas de saúde. Interface - Comunic., Saúde, Educ., v.8, n.14, p.73-92, set.2003-fev.2004.

BARBOSA, Ivani; DUARTE, Maria Jalma Rodrigues Santana. Envelhecimento e Política de saúde:uma questão de cidadania. Rev. Enf. UERJ, Rio de Janeiro, v. 9, n. 2, p.138-143, 2001

BASTIDE, Paul Arbousse. A idéia do tempo e o envelhecimento. Rev. A Terceira Idade, São Paulo, ano 10, n 16, p. 3-11, maio 1999.

BEAINI, Thaís Curi. À escuta do silêncio: um estudo sobre a linguagem no pensamento de Heidegger. São Paulo: Cortez, 1981.

BEAUVOIR, Simone de. A Velhice. Trad. Maria Helena Franco Monteiro. Rio de Janeiro: Nova Fronteira, 1990.

BICUDO, Maria Aparecida Viggiano. Fenomenologia: confrontos e avanços. São Paulo: Cortez, 2000. Cap. 2, p. 71-102: A pesquisa qualitativa fenomenológica à procura de procedimentos rigorosos.. 
BITTENCOURT, Maria Inês Garcia de Freitas. Reflexões sobre o tempo: instrumentos para uma viagem pelo ciclo vital. Psyché, São Paulo, ano 9, n. 15, p.93-104, jan-jun. 2005.

BOARETTO, Roberta Cristina. Cinema, Realidade e Cotidiano: imagens de um velho nas ruas. In: GUSMÃO, Neusa Maria Mendes de (Org.). Cinema, velhice e cultura. Campinas: Alínea, 2005. p. 45-57. Coleção Velhice e Sociedade.

BOEMER, Magali Roseira. A condução de estudos segundo a metodologia de investigação fenomenológica. Revista Latino- am. Enfermagem, Ribeirão Preto, v. 2, n.1, p. 83-94. jan. 1994.

BOEMER, Magali Roseira; ZANETTI, Maria Lúcia ; VALLE, Elizabeth R. Martins do. A idéia de morte no idoso - uma abordagem compreensiva. In: CASSORLA, Roosevelt M. S. (Coord.). Da morte: estudos brasileiros. Campinas: Papirus,1998. p.119 - 129.

BORINI, Maria Lúcia Oliveti; CINTRA, Fernanda Aparecida. Representações sociais da participação em atividades de lazer em grupos de terceira idade. Rev. Bras. Enferm., Brasília, v.55, n 5, p. 568-574. set./out. 2002.

BOSCOV, Isabela. Para ficar de cabelos brancos. Veja. n 37. edição 1871. p. 106-108. set. 2004

BOSI, Ecléa. Memória e Sociedade: lembrança de velhos. 3 ed.. São Paulo: Companhia das Letras, 1994. 
BRASIL. Constituição da República Federativa do Brasil, capítulo VII: da família, da criança, do adolescente e do idoso, 1998.

BRASIL. Lei 8.842, de 04.01.94 (regulamentada pelo Dec. 1.958, de 03.07.96). Dispõe sobre a Política Nacional do Idoso.

BRASIL. Lei $\mathrm{n}^{\circ} 10.741$, de $1^{\circ}$ de outubro de 2003. Dispõe sobre o Estatuto do Idoso e dá outras providências. Centro de Documentação e Informação - Coordenação de Publicações, Brasília, 2004.

BRUM, Ana Karine Ramos; TOCANTINS, Florence Romijn; SILVA, Teresinha de Jesus do Espírito Santo da. O enfermeiro como instrumento de ação no cuidar do idoso. Rev Latinoam. Enfermagem, Ribeirão Preto, v.13, n.6, p.1019-1026, 2005. Disponível em: http://www.scielo.br/pdf/rlae/v13n6/v13n6a15.pdf. Acesso em: 05 fev. 2007.

CALDAS, Célia Pereira. A dimensão existencial da pessoa idosa e seu cuidador. Textos Envelhecimento. Rio de Janeiro v. 3, n. 4, jul. 2000. Disponível em: http://www.unati.uerj.br/tse/scielo.php?script=sci_arttext\&pid=S151759282000000200004\&lng=pt\&nrm=iso. Acesso em: 11 maio 2007.

CAMARANO, Ana Amélia. Envelhecimento da população brasileira: uma contribuição demográfica. Local: IPEA, jan. 2002. (Textos para discussão n. 858).

CAPALBO, Creusa. Prefácio. In CARVALHO, Anésia de Souza. Metodologia da entrevista: uma abordagem fenomenológica. Rio de Janeiro: Agir, 1987. 87 p. 
CAPALBO, Creusa. Considerações sobre o método fenomenológico e a enfermagem. Rev. Enferm. UERJ, v.2, n. 2, p. 192-197, out. 1994.

CARVAlHO, Anésia de Souza. Metodologia da Entrevista: uma abordagem fenomenológica. Rio de Janeiro: Agir, 1987. 87 p.

CARVALHO, José Alberto Magno de; GARCIA, Ricardo Alexandrino. O envelhecimento da população brasileira: um enfoque demográfico. Cad. Saúde Pública. Rio de Janeiro, v. 19, n. 3, p. 725-733, 2003. Disponível em: http://www.scielo.br/pdf/csp/v19n3/15876.pdf Acesso em: 10/02/2007.

CARVALHO, Vilma de. Enfermagem fundamental - predicativos e implicações. Rev. Latino-am. Enfermagem. v. 11, n. 5, p. 664-671, set.-out. 2003. Disponível em: http://www.scielo.br/pdf/rlae/v11n5/v11n5a15.pdf. Acesso em: 08 fev. 2007.

CASALI, Paulo Antonio. Envelhecer com saúde. Rev. Homeopatia e Cia, n.6, março 2004. Disponível em: http://www.homeopatiaecia.com.br/revista6.html. Acesso em: 04 julho 2005.

CIDRACK, Marlene Lopes; CATRIB, Ana Maria Fontenelle; AMORIM, Rosendo Freitas de. Re-aprendendo a Viver. Revista Bras. Promoção da Saúde - RBPS, v. 17, n. 3, p. 138-148, 2004.

COBRA, Rubem Queiroz. Martin Heidegger. Filosofia Contemporânea. 2001. Disponível em: http://www.cobra.pages.nom.br. Acesso em: 23 abril 2007. 
COELHO, Neusa Lais Aposentadoria. São Paulo: Instituto Tempos Modernos, 1999. Trabalho apresentado na Jornada "Violência - Mancha Social", 22 e 23 de outubro de 1999.

COLPO, Marcos Oreste. A cura (Sorge) e a virtude da prudentia - a queda (Verfallen) do Dasein e o pecado da Acídia (a ontologia fundamental de M.Heidegger e o pensamento de Tomás de Aquino). s.d. Disponível em: http://www.hottopos.com/notand11/colpo.htm. Acesso em: 02 março 2007.

CORRÊA, Adriana Kátia. Fenomenologia: uma alternativa para pesquisa em enfermagem. Rev. Latino-am. Enfermagem, Ribeirão Preto, v. 5, n. 1, p.83-88, janeiro 1997.

Do treinamento do enfermeiro à possibilidade da educação em terapia intensiva: em busca do sentido da existência humana. 2000. 212 f. Tese (Doutorado) Escola de enfermagem de Ribeirão Preto da Universidade de São Paulo, Ribeirão Preto, 2000.

CURY, Augusto. 12 semanas para mudar uma vida. Colina: Academia de Inteligência, 2004.

DEBERT, Guita Grin. Gênero e Envelhecimento. Estudos Feministas. v. 2, n. 3, p. 33-51, 1994.

. Envelhecimento e curso da vida. Estudos Feministas. n. 1, p. 120-

$128,1997$. 
. A reinvenção da velhice: socialização e processos de reprivatização do envelhecimento. São Paulo: EDUSP, 1999.

. O significado da velhice na sociedade brasileira. Acta Paul. Enferm., v. 13, número especial, parte I, p. 147-158, 2000.

Os significados da velhice no curso da vida pós - moderna. s.d. Disponível em: http://www.odialetico.hpg.ig.com.br/filosofia/debert.htm. Acesso em: 22 nov. 2006.

DIOGO, Maria José D’Elboux. O papel da enfermeira na reabilitação do idoso. Rev.latinoam. Enfermagem, Ribeirão Preto, v. 8, n. 1, p. 75-81, janeiro 2000.

Formação de recursos humanos na área da saúde do idoso.

Rev. Latino-am Enfermagem; Ribeirão Preto, v. 12, n. 2, p.280-282, março-abril 2004.

DÖPPENSCHMITT, Ellen. Velhice e memória em Copacabana. In: GUSMÃO, Neusa Maria Mendes de (Org.). Cinema, Velhice e Cultura. Campinas: Alínea, 2005. p. 59-71. Coleção Velhice e Sociedade.

DUARTE, Lúcia Regina Severo. Idade cronológica: mera questão referencial no processo de envelhecimento. Estud. Interdiscip. Envelhec., Porto Alegre, v. 2, p. 35-47, 1999.

DUARTE, Maria Jalma Rodrigues Santana. Atenção ao Idoso: um problema de saúde pública e de enfermagem. R. Enferm. UERJ, RJ, v. 2, n 1, p. 100-11. maio 1994 
DUARTE, Yeda Aparecida de Oliveira; LEBRÃO, Maria Lúcia. O cuidado gerontológico: um repensar sobre a assistência em gerontologia. In: PESSINI, Leocir; BARCHIFONTAINE, Christian de Paul de (Orgs). Bioética e longevidade humana. São Paulo: Centro Universitário São Camilo; Loyola, 2006. p. 467-484.

ERDMANN, Alacoque Lorenzini. Tecnologia em Enfermagem Geriátrica e Gerontológica. Texto e Contexto Enferm., Florianópolis, v. 2, n. 6, p. 151-154, 1997.

; RAMOS, Flávia Regina; REIBNITZ, Kenya Schmidt; PRADO, Marta Lenise do. Educação em bioética: desafios para a formação crítico-criativa dos profissionais de enfermagem. In: PESSINI, Leocir; BARCHIFONTAINE, Christian de Paul de (Orgs). Bioética e longevidade humana. São Paulo: Centro Universitário São Camilo; Loyola, 2006. p. 237-250.

FERREIRA, Ana Maria Tucci Gammaro Baldavira; DERNTL, Alice Moreira. Ouvindo o idoso hospitalizado: direitos envolvidos na assistência cotidiana de enfermagem. In: PESSINI, Leocir; BARCHIFONTAINE, Christian de Paul de (Orgs). Bioética e longevidade humana. São Paulo: Centro Universitário São Camilo; Loyola, 2006. p. 445-465.

FERRIGNO, José Carlos. O estigma da velhice: uma análise do preconceito aos velhos à luz das idéias de Erving Goffman. A Terceira Idade, São Paulo, v.13, n. 24, p.48-56, abr. 2002.

A co-educação entre gerações: um desafio da longevidade. In: PESSINI, Leocir; BARCHIFONTAINE, Christian de Paul de (Orgs). Bioética e longevidade humana. São Paulo: Centro Universitário São Camilo; Loyola, 2006. p. 329-352. 
FIGUEIREDO, Maria do Livramento Fortes; TYRREL, Maria Antonieta Rubio. O gênero (in)visível da terceira idade no saber da enfermagem. Rev. Bras. Enferm. v. 58, n. 3, p. 330334, maio-jun. 2005.

FIGURELLI, Roberto. Envelhecimento e morte na obra de Ingmar Bergman. In: GUSMÃO, Neusa Maria Mendes de (Org.). Cinema, velhice e cultura. Campinas: Alínea, 2005, p. 123134. Coleção Velhice e Sociedade.

FOGAÇA, Maria Cristina Costa Braga Hortelli. Idoso + conhecimento sobre o envelhecimento $=$ novas perspectivas de vida. Revista da APG, São Paulo, ano 8, n 17, p. 203-207, maio 1999.

FORGHIERI, Yolanda Cintrão. Psicologia fenomenológica: fundamentos, método e pesquisa. São Paulo: Pioneira Thomson Learning, 2004.

FREIRE JR., Renato Campos; TAVARES, Maria de Fátima Lobato. A saúde sob o olhar do idoso institucionalizado: conhecendo e valorizando sua opinião. Interface - Comunic., Saúde, Educ., v.9, n.16, p.147-58, set. 2004-fev. 2005.

FRUMI, Cailene; CELICH, Kátia Lilian Sedrez. O olhar do idoso frente ao envelhecimento e à morte. RBCEH - Rev. Bras. Ci. Envelhecimento Humano, Passo Fundo, p. 92-100, jul.dez. 2006

GARRIDO, Regiane; MENEZES, Paulo R. O Brasil está envelhecendo: boas e más notícias por uma perspectiva epidemiológica. Rev. Bras. Psiquiatr. v. 24, p. 3-6, 2002 supl 1. 
GELAIN, Ivo; ALVAREZ, Ângela Maria; SILVA, Rode D. M. da. A enfermagem e o envelhecimento humano: aspectos éticos. Texto \& Contexto Enferm., Florianópolis, v.6, n.2, p. 221-232, mai.-ago. 1997

GOLDSTEIN, Lucila L. Produção científica brasileira na área da gerontologia: (1975-1999). Rev. Online Bibl. Prof. Joel Martins, v. 1, n.1, out. 1999.

GONÇALVES, Lúcia Hisako Takase; ALVAREZ, Ângela Maria. A enfermagem gerontogeriátrica: perspectiva e desafios. RBCEH - Ver. Bras. Ci. Envelhecimento Humano, Passo Fundo, p. 57-68, jan.-jun. 2004.

GUERREIRO, Tânia; RODRIGUES, Regina. Envelhecimento bem-sucedido: utopia, realidade ou possibilidade? Uma abordagem transdisciplinar da questão cognitiva. In: VERAS, Renato Peixoto. Terceira Idade: alternativas para uma sociedade em transição. local: Relume-Dumará, 1999. p. 51-69.

HEIDEGGER, Martin. Todos nós...ninguém: um enfoque fenomenológico do social. Trad. Dulce Maria Critelli. São Paulo: Moraes, 1981.

. Ser e Tempo. Trad. Márcia Sá Cavalcante Schuback. 13 ed. Petrópolis: Vozes, 2005. Parte I.

.. Ser e Tempo. Trad. Márcia Sá Cavalcante Schuback. 13 ed.

Petrópolis: Vozes, 2005. Parte II. 
HEINSIUS, Ana Maria. O Processo de Envelhecimento. s.d. Disponível em: http://www.jsa.med.br/Terceiraidade.htm. Acesso em: 17 junho 2005.

INSTITUTO BRASILEIRO DE GEOGRAFIA E ESTATÍSTICA - IBGE. Censo demográfico: Brasil, 2000. Rio de Janeiro, 2000.

Perfil dos idosos responsáveis por domicílios no Brasil. Série Estudos \& Pesquisas: informação demográfica e socioeconômica. Rio de Janeiro, 2000.

JACQUES, Maria da Graça Côrrea; CARLOS, Sérgio Antonio. Identidade, aposentadoria e o processo de envelhecimento. 2002 Disponível em:

http://www.comciencia.br/reportagens/envelhecimento/texto/env15.htm Acesso em: 26 junho 2006.

JARDIM, Viviane Cristina Fonseca da Silva; MEDEIROS, Bartolomeu Figueiroa de; BRITO, Ana Maria de. Um olhar sobre o processo de envelhecimento: a percepção de idosos sobre a velhice. Rev. Bras. Geriatr. Gerontol., Rio de Janeiro, v. 9, n. 2, p. 1-10, 2006.

JUNQUEIRA, Ester Dalva Silvestre. Velho. E, por que não? Bauru: EDUSC, 1998.

KOMATSU, Ricardo S. In: RODRIGUES, Rosalina Aparecida Partezani; DIOGO, Maria José D’ Elboux (Orgs). Como cuidar dos idosos. Introdução. Campinas: Papirus, 1996. Coleção Vivaidade. 
LEBRÃO, Maria Lúcia. Seminário velho amigo discute o cenário do idoso no Brasil e papel da sociedade civil. 2006

Disponível em: www.velhoamigo.org.br/images/seminariovelhoamigo.pdf. Acesso em: 22 fev. 2007.

LEITE, Marinês Tambara; CAPPELLARI, Viviane Tolfo; SONEGO, Joseila Mudou, mudou tudo na minha vida: experiências de idosos em grupos de convivência no município de Ijuí/RS. Revista Eletrônica Enferm., Goiânia, v. 4, n. 1, p. 18 - 25, 2002. Disponível em: http://www.fen.ufg.br/revista/revista4 1/index.html. Acesso em: 08 fev. 2007.

LIMA, Maria José de. O que é Enfermagem? Cogitare Enferm., v. 10, n. 1, p. 71-74, jan.abril 2005.

LIMA-COSTA, Maria Fernanda; VERAS, Renato Peixoto. Saúde Pública e Envelhecimento. Cad. Saúde Pública, Rio de Janeiro, v. 19, n. 3, p. 700-701, jun. 2003.

LOPES, Regina Lúcia Mendonça; RODRIGUES, Benedita Maria Rêgo Deusdará; DAMASCENO, Marta Maria Coelho. Fenomenologia e a pesquisa em enfermagem. Rev. Enferm. UERJ, Rio de Janeiro, v. 3, n. 1, p. 49-52, maio 1995.

LOPES, Regina Lúcia Mendonça; SOUZA, Ívis Emília Oliveira. A fenomenologia como abordagem metodológica: compartilhando a experiência de mulheres que buscam a prevenção do câncer cérvico-uterino. Rev. Latino-am. Enfermagem, Ribeirão Preto, v. 5, n. 3, p. 5-11, jul. 1997. 
MACHADO DE OLIVEIRA, Cristina G. A questão do Ser. s.d. Disponível em: http://www.filosofiavirtual.pro.br/serheidegger.htm. Acesso em: 10 abril 2007.

MAGRO, Viviane M. de Mendonça. Espelho em negativo: a idade do outro e a identidade etária. In: Gusmão, Neusa Maria Mendes de (Org). Infância e velhice: pesquisa de idéias. Campinas: Alínea, 2003. Cap. 2; p. 33- 46.

MARTINS, Joel. Contribuição da fenomenologia à psicologia clínica: imaginação e fantasia. In: FORGHIERI, Yolanda Cintrão (Org.). Fenomenologia e psicologia. São Paulo: Cortez, 1984. p. 131-143.

MARTINS, Joel; BOEMER, Magali Roseira; FERRAZ, Clarice Aparecida. A fenomenologia como alternativa metodológica para pesquisa: algumas considerações. Rev. Esc. Enferm. USP, São Paulo, v. 24, n. 1, p. 139-147, abr. 1990.

MAUAD, Leonor Campos. Sabedoria e revisão de vida: o desempenho de um grupo de mulheres em diferentes idades. 1997. 189 f. Tese (Doutorado) - Faculdade de Educação da UNICAMP, Campinas, 1997.

MENDES, Iranilde José Messias. Promoção de saúde: caminhando para o único. 1996. 175 f. Tese (Livre Docência) - Escola de Enfermagem de Ribeirão Preto da Universidade de São Paulo, Ribeirão Preto, 1996. 
MENDES, Márcia R. S. S. Barbosa ; GUSMÃO, Josiane Lima de; FARO, Ana Cristina Mancussi e ; LEITE, Rita de Cássia Burgos de O. A situação social do idoso no Brasil: uma breve consideração. Acta Paul. Enferm., São Paulo, v. 18, n. 4, p. 422-426, 2005.

MENDES, Maria Manuela Rino. Enfermagem gerontológica e geriátrica: do estado da arte no Brasil a uma proposta para o ensino de graduação. 1989. 231 f. Dissertação (Mestrado) Escola de Enfermagem de Ribeirão Preto da Universidade de São Paulo, Ribeirão Preto, 1989.

MINAYO, Maria Cecília de Souza; COIMBRA JR., Carlos E. A. Entre a liberdade e a dependência: reflexões sobre o fenômeno social do envelhecimento. In: Minayo, Maria Cecília de Souza (Org.). Antropologia, saúde e envelhecimento. Rio de Janeiro: Editora FIOCRUZ, 2002.

MORAES, Edgar Nunes de. Gerontologia básica. s.d. Disponível em: http://ciape.org.br/matdidatico/edgar/Livro_Ger_Bas_Demo_Fisiologia_Env.doc. Acesso em: 16 abril 2007.

NERI, Anita Liberalesso. In: Gusmão, Neusa Maria Mendes de (Org). Infância e velhice: pesquisa de idéias. Prefácio. Campinas: Alínea, 2003.

Palavras-chave em gerontologia. 2 ed. Campinas: Alínea, 2005.

Coleção Velhice e Sociedade. 
OGUISSO, Taka. A enfermagem no mundo atual e projeções para o futuro. Acta Paul Enferm., São Paulo, v. 13, número especial, parte I, p.44-52, 2000.

OLIEVENSTEIN, Claude. O nascimento da velhice. Trad. Viviane Ribeiro. Bauru: EDUSC, 2001. $156 \mathrm{p}$.

OMERY, Anna. Fenomenologia: um método para pesquisa em enfermagem. Adv. Nurs. Sci., n. 52, p. 49-63, jan. 1983.

ORGANIZAÇÃO MUNDIAL DE SAÚDE OMS. Envelhecimento ativo: uma política de saúde. Trad. Suzana Gontijo. Brasília: Organização Pan-Americana da Saúde, 2005.

ORGANIZACIÓN PANAMERICANA DA LA SALUD OPS. Enfermería gerontológica: conceptos para la practica. Washington, DC., 1993. Serie PALTEX, n 31.

Envelhecimento e Saúde: Um novo paradigma. Washington, D.C., Jul. 1998.

PAPALÉO NETTO, Matheus; YUASO, Denise Rodrigues; KITADAI, Fábio Takashi. Longevidade: desafio no terceiro milênio. In: PESSINI, Leocir; BARCHIFONTAINE, Christian de Paul de (Orgs.). Bioética e longevidade humana. São Paulo: Centro Universitário São Camilo; Loyola, 2006. p. 259-287. 
PASCHOAL, Sérgio Márcio Pacheco. Desafios da longevidade: qualidade de vida. In: PESSINI, Leocir; BARCHIFONTAINE, Christian de Paul de (Orgs.). Bioética e longevidade humana. São Paulo: Centro Universitário São Camilo; Loyola, 2006. p. 329-337.

PAVARINI, Sofia Cristina Iost; MENDIONDO, Marisa Silvana Zazzetta de; BARHAM, Elizabeth Joan; VAROTO, Vania Aparecida Gurian; FILIZOLA, Carmen Lúcia Alves. A arte de cuidar do idoso: gerontologia como profissão? Texto \& Contexto Enferm., Florianópolis, v.14, n.3, p. 01- 09, 2005.

PESSINI, Leo; BERTACHINI, Luciana. Novas perspectivas em cuidados paliativos: ética, geriatria, gerontologia, comunicação e espiritualidade. In: PESSINI, Leocir; BARCHIFONTAINE, Christian de Paul de (Orgs.). Bioética e longevidade humana. São Paulo: Centro Universitário São Camilo; Loyola, 2006. p. 353-391.

PRADO, Shirley Donizete; SAYD, Jane Dutra. Teses e dissertações sobre envelhecimento no Brasil. Textos Envelhecimento, Rio de Janeiro, v. 7, n. 1,. p. 1-14, 2004a. Disponível em: http://www.unati.uerj.br/tse/scielo.php?script=sci_arttext\&pid=S151759282004000100003\&lng=pt\&nrm=iso. Acesso em: 15 abril 2007.

A pesquisa sobre envelhecimento humano no Brasil: grupos e linhas de pesquisa. Ciênc. Saúde Coletiva, Rio de Janeiro, v. 9, n. 1, p. 5767, 2004b. Disponível em: http://www.scielo.br/pdf/csc/v9n1/19823.pdf Acesso em: 15 abril 2007. 
A produção científica sobre envelhecimento

e saúde no Brasil. Textos Envelhecimento, Rio de Janeiro, v. 7, n. 2, p. 1-12, 2004c.

Disponível em: http://www.unati.uerj.br/tse/scielo.php?script=sci_arttext\&pid=S151759282004000200006\&lng=pt\&nrm=iso Acesso em: 15 abril 2007.

SALGADO, Marcelo Antonio. A aposentadoria e ética social. Rio de Janeiro CBCISS, 1990. p. 14-24. Coleção Temas Sociais, n 230.

SALGADO, Carmen Delia Sánchez. Mulher idosa: a feminização da velhice. Estud. Interdiscip. Envelhec. Porto Alegre, v. 4, p. 7-19, 2002.

SANTANA, Rosemeire Ferreira; SANTOS, Iraci dos. Como tornar-se idoso: um modelo de cuidar em Enfermagem Gerontológica. Texto \& Contexto Enferm., Florianópolis, v. 14, n 2, 2005.

SCHIRRMACHER, Frank. A ditadura dos jovens. Veja, p. 11 - 15, 18 ago.2004.

A revolução dos idosos: o que muda no mundo com o aumento da população mais velha. Trad. Maria do Carmo Ventura Wolly. Rio de Janeiro: Elsevier, 2005.

SILVA, Alcione Leite. A dimensão humana do cuidado em enfermagem. Acta Paul. Enferm., São Paulo, v. 13, número especial, parte I, p. 86-90. 2000. 
SILVA, Iolete Ribeiro da; GÜNTHER, Isolda de Araújo. Papéis sociais e envelhecimento em uma perspectiva de curso de vida. Psicologia: Teoria e Pesquisa, Brasília, v. 16, n. 1, p. 31 40, jan.-abr. 2000.

SILVA, Marina da Cruz. O processo de envelhecimento no Brasil: desafios e perspectivas.

Textos Envelhecimento, Rio de Janeiro, v. 8, n. 1, 2005. Disponível em: http://www.unati.uerj.br/tse/scielo.php?script=sci_arttext\&pid=S151759282005000100004\&lng=pt\&nrm=iso. Acesso em: 15 abril 2007.

SILVESTRE, Jorge Alexandre, KALACHE, Alexandre, RAMOS, Luiz Roberto, VERAS, Renato Peixoto. O envelhecimento populacional brasileiro e o setor saúde. Arq. Geriatr. Gerontolo., . n. 1, p. 81-89, 1996.

SIMÕES, Sonia Mara Faria; SOUZA, Ívis Emília Oliveira. Um caminhar na aproximação da entrevista fenomenológica. Rev. Latino-am. Enfermagem, Ribeirão Preto, v. 5, n. 3, p. 1317, jul. 1997.

SIQUEIRA, Renata Lopes de; BOTELHO, Maria Izabel Vieira; COELHO, France Maria Gontijo. A velhice: algumas considerações teóricas e conceituais. Ciênc. Saúde Coletiva, Rio de Janeiro, v. 7, n. 4, p. 899-906, 2002.

STEAVENSON, Joane; GONÇALVES, Lúcia; ALVAREZ, Ângela M. O cuidado e a especificidade da enfermagem geriátrica e gerontológica. Texto \& Contexto Enferm., Florianópolis, v. 2, n. 6, p. 33-50, mai/ago. 1997. 
STEIN, Ernildo. Seis estudos sobre ser e tempo. Petrópolis: Vozes, 1988.

STEINER, George. As idéias de Heidegger. Trad. de Álvaro Cabral. São Paulo: Cultrix, 1978.

TAVARES, Samila Sathler. O que rima com idade? Identidade e sociabilidade na velhice em tempos de transição. In: GUSMÃO, Neusa Maria Mendes de (Org.). Cinema, velhice e cultura. Campinas: Alínea, 2005. p. 101-110. Coleção Velhice e Sociedade.

TERCEIRA IDADE - um desafio para todos. s.d. Disponível em: (http://www.mabesa.com.br/dicas_saude03.htm). Acesso em: 23 nov. 2006.

TOLEDO, Edegarda Helena Rusisca de; DIOGO, Maria José D'Elboux. Idosos com afecção onco-hematológica: ações e as dificuldades para o autocuidado no início da doença. Rev. Latino-am. Enfermagem, Ribeirão Preto, v. 11, n. 6, p. 707-712, 2003. Disponível em: http://www.scielo.br/pdf/rlae/v11n6/v11n6a02.pdf. Acesso em: 16 abril 2007.

VERAS, Renato Peixoto. In: Minayo, Maria Cecília de Souza (org.). Antropologia, saúde e envelhecimento.Prefácio. Rio de Janeiro: Editora FIOCRUZ, 2002.

VON FABER, Margaret; VAN DER WIEL, Annetje Bootsma; VAN EXEL, Eric; GUSSEKLOO, et al. Successful aging in the oldest old: who can be characterized as successfully aged? Arch Intern Med., v. 161, n. 22, p. 2694-2700. Dec. 2001. 
WALDOW, Vera Regina; LOPES, Marta Júlia Marques; MEYER, Dagmar Estermann. Maneiras de cuidar, maneiras de ensinar: a enfermagem entre a escola e a prática profissional. Porto Alegre: Artes Médicas, 1995.

ZIMERMAN, Guite I. Velhice: aspectos biopsicosociais. Porto Alegre: Artmed, 2005. 
Apêndices 
Apêndice $A$ 


\section{Apêndice A - Termo de Consentimento Livre e Esclarecido}

\section{A pesquisadora responsável pelo estudo A Vivência do Envelhecer na Perspectiva} Fenomenológica: significados para prática de enfermagem, sou eu, Maria da Graça da Silva, enfermeira, professora do Curso de Enfermagem da Universidade Federal de Mato Grosso do Sul.

A questão que me preocupa é: o que significa vivenciar o envelhecer? Ser sujeito neste processo de envelhecer? Conheço alguns aspectos teóricos deste assunto, das leituras que realizei, dos estudos e da minha experiência como enfermeira e professora. No entanto, entendo que é a pessoa que vivencia uma situação ou um momento de sua vida, que tem muito a ensinar sobre ele.

Assim, para compreender o significado de estar envelhecendo, na perspectiva das pessoas que vivenciam essa situação, necessito de sua participação que constará de uma entrevista, permitindo-me utilizar sua fala no relato da pesquisa.

Preciso gravar a entrevista, mas o(a) Sr.(a) tem o direito de recusar. Nesse caso, após o encontro, farei uma síntese do que foi dito pelo(a) Sr.(a).

Informo ainda que:

- $O(a)$ senhor(a) tem direito de não participar da pesquisa, se assim o desejar. Isto em nada afetará sua participação neste serviço.

- Caso o(a) senhor(a) aceite participar, garanto seu anonimato e privacidade quanto ao seu nome e as informações prestadas.

- Em momento algum o (a) senhor(a) estará sob condição de risco físico ou emocional;

- Caso o(a) senhor(a) tenha aceitado participar mas, por qualquer motivo, durante o andamento da pesquisa, resolver desistir, tem toda a liberdade para retirar o seu consentimento.

- Sua colaboração e participação poderão trazer benefícios para a atuação do enfermeiro nas funções assistenciais e da profissão como um todo.

Por estas razões, gostaria de poder contar com sua valiosa cooperação, a qual desde já agradeço.

Caso necessite falar comigo, após a entrevista, deixo um telefone para que o(a) $\operatorname{Sr}(a)$ possa entrar em contato;

Tel. para contato: 3365-4621 (res.); 3345-7353 (com.)

Atenciosamente, 
$\mathrm{Eu}$ , declaro que tomei conhecimento das informações referentes à pesquisa A VIVÊNCIA DO ENVELHECER NA PERSPECTIVA FENOMENOLÓGICA: significados para prática de enfermagem, da pesquisadora Maria da Graça da Silva. Entendi - as e não tenho dúvidas a respeito do que será tratado.

Desta forma, consinto em participar como sujeito dessa pesquisa.

Campo Grande/MS, de de 200

Assinatura do participante e/ou responsável

Maria da Graça da Silva

Pesquisadora responsável 
Apêndice B 


\section{Apêndice B - Autorização da Secretaria Municipal de Assistência Social}

Campo Grande, 20 de fevereiro de 2005

\section{Prezado Sra.}

Lacy Severo Pupim

Mui digna Secretária Municipal de Assistência Social de Campo Grande-MS

Cumprimentando V.S ., venho por meio desta apresentar-me: sou Maria da Graça da Silva, enfermeira, docente do curso de graduação em Enfermagem da Universidade Federal de Mato Grosso do Sul e Diretora de Educação da Associação Brasileira de Enfermagem seção MS., e estarei iniciando pós-graduação, nível doutorado, na Escola de Enfermagem de Ribeirão Preto, da Universidade de São Paulo, a partir deste mês.

Portanto, venho mui respeitosamente, solicitar permissão para desenvolver o projeto de pesquisa intitulado “A Vivência do Envelhecer na Perspectiva Fenomenológica: significados para prática de enfermagem", junto aos freqüentadores do Centro de Convivência do Idoso "João Nogueira Vieira" - Centro - Av. Fernando Corrêa da Costa - 350, Anexo Horto Florestal, e do Centro de Convivência "Elias Lahdo", Av. Monte Castelo, 456, Bairro Monte Castelo, na cidade de Campo Grande/MS. O projeto estará sob minha responsabilidade, com orientação da $\operatorname{Prof}^{\mathrm{a}}$. Dr ${ }^{\mathrm{a}}$. Magali Roseira Boemer.

Neste momento estarei realizando uma aproximação com os referidos Centros, e comprometo-me a apresentar cópia do projeto assim que estiver totalmente finalizado e aprovado nas devidas instâncias da UFMS e da EERP/USP.

Contando com a colaboração de V.S , desde já agradeço, colocando-me à disposição para quaisquer esclarecimentos que se fizerem necessários.

Atenciosamente,

Prof. ${ }^{a}$ Maria da Graça da Silva

e-mail: gracasilva-ms@,brturbo.com.br

Tel.: 67- 3345-7353 (Departamento de Enfermagem/UFMS)

3365-4621 (residência); 9906-3607 (celular) 
Anexos 
Anexo $A$ 

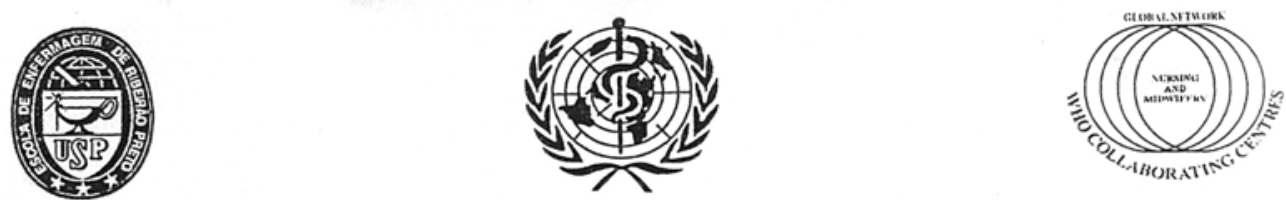

ESCOLA DE ENFERMAGEM DE RIBEIRÃO PRETO - UNIVERSIDADE DE SÃO PAULO CENTRO COLABORADOR DA ORGANIZAÇÃO MUNDIAL DA SAÚDE PARA O DESENVOLVIMENTO DA PESQUISA EM ENFERMAGEM

Avenida Bandeirantes, 3900 - Campus Universitário - Ribeirão Preto - CEP 14040-902 - São Paulo - Brasil FAX: $55-16-633-3271 / 55-16-630-2561$ - TELEFONES: 55 - 16 - 633-0379/602-3382

\section{COMITÊ DE ÉTICA EM PESQUUISA DA EERP/USP}

Of.CEP-EERP/USP - 019/2006

Ribeirão Preto, 17 de fevereiro de 2006

Prezada Senhora,

Comunicamos que o projeto de pesquisa, abaixo especificado, foi analisado e considerado APROVADO pelo Comitê de Ética em Pesquisa da Escola de Enfermagem de Ribeirão Preto da Universidade de São Paulo, em sua $83^{a}$ Reunião Ordinária, realizada em 17 de fevereiro de 2006.

Protocolo: $n^{\circ} 0610 / 2005$

Projeto: A VIVÊNCIA DO ENVELHECER NA PERSPECTIVA FENOMENOLÓGICA: SIGNIFICADOS PARA PRÁTICA DE ENFERMAGEM

Pesquisadores: MAGALI ROSEIRA BOEMER (Orientadora) MARIA DA GRAÇA DA SILVA (Doutoranda)

Em atendimento à Resolução 196/96, deverá ser encaminhado ao CEP o relatório final da pesquisa e a publicação de seus resultados, para acompanhamento, bem como comunicada qualquer intercorrência ou a sua interrupção.

Atenciosamente,

$$
\text { Lenula C. Nasinento. }
$$

Praf ${ }^{a} \mathfrak{r}^{a}$ Cléa Regina de Oliveira Ribeira

Coordenadora do CEP-EERP/USP

IIma. Sra.

Profa $^{a}$. Dra . Magali Roseira Boemer (Orientadora)

Dept $^{\circ}$ de Enfermagem Geral e Especializada

Escola de Enfermagem de Ribeirão Preto - USP 
Anexo B 


\title{
Universidade Federal de Mato Grosso do Sul Comitê de Ética em Pesquisa /CEP/UFMS
}

\author{
Carta de Aprovação
}

A minha assinatura neste documento, atesta que o protocolo $n^{\circ} 794$ da Pesquisadora Maria da Graça da Silva intitulado "A vivência do envelhecer na perspectiva fenomenológica: significados para prática de enfermagem", e o seu Termo de Consentimento Livre e Esclarecido, foram revisados por este comitê e aprovados em reunião Extraordinária no dia 19 de junfo de 2006, encontrando-se de acordo com as resoluções normativas do Ministério da Saúde.

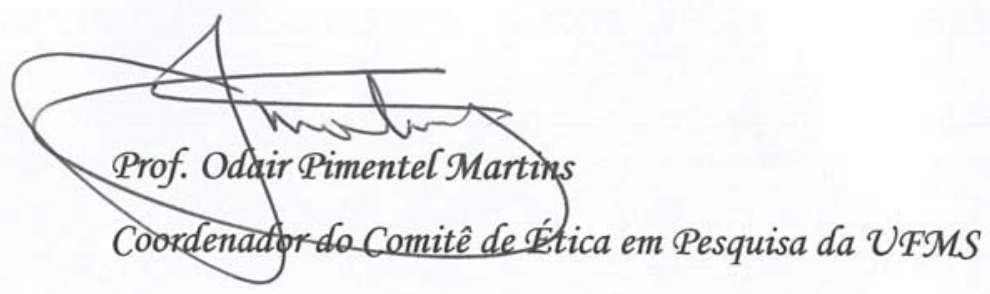

Campo Grande, 20 de junfio de 2006. 


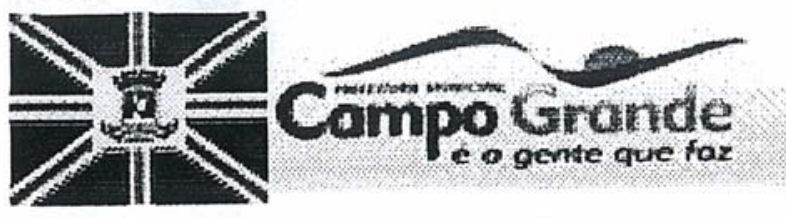

Campo Grande, 23 de janeiro de 2006

Ao Comitê de Ética em Pesquisa da Escola de Enfermagem de Ribeirão Preto/USP

Endossamos a permissão anteriormente concedida pela Sra. Lacy Severo Pupim, mui digna Secretária Municipal de Assistência Social de Campo Grande-MS, a Maria da Graça da Silva, para desenvolver o projeto de pesquisa intitulado "A Vivência do Envelhecer na Perspectiva Fenomenológica: significados para prática de enfermagem”, junto aos freqüentadores dos Centros de Convivência do Idoso "João Nogueira Vieira" - Centro Av. Fernando Corrêa da Costa - 350, Anexo Horto Florestal, e "Elias Ladho" - Avenida Monte Castelo, s/n, Bairro Monte Castelo, ambos na cidade de Campo Grande/MS.

A pesquisadora terá acesso às dependências dos Centros para desenvolver a pesquisa conforme metodologia apresentada no projeto.

Atenciosamente,

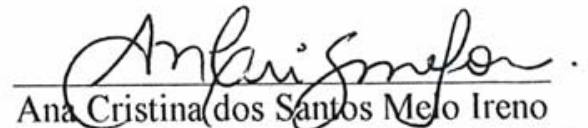

Coordenadora do CCI "João Nogueira Vieira"

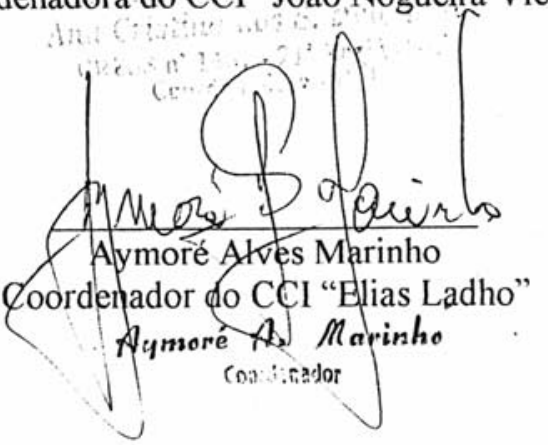


MINISTÉRIO DA EDUCAÇÃO

UNIVERSIDADE FEDERAL DE MATO GROSSO DO SUL

PRÓ-REITORIA DE PESQUISA E PÓS-GRADUAÇÃO

COORDENADORIA DE PESQUISA

PARECER DA COMISSÃO DE PESQUISA

Número: 246/06

Data 22/05/2006

De: Chefe da Coordenadoria de Pesquisa - CPq/PROPP

De: Presidente da Comissão de Pesquisa - CP/PROPP

Para: Prof $f^{a}$ MARIA DA GRAÇA DA SILVA

Depto: DEN/CCBS

Orientador:

Projeto no: $\quad 2006 / 0080$

Período de execução:

Início: $\quad 02 / 2006$

Título do Projeto:

Término: $\quad 12 / 2007$

"A VIVÊNCIA DO ENVELHECER NA PERSPECTIVA FENOMENOLÓGICA: SIGNIFICADOS PARA PRÁTICA DE ENFERMAGEM".

Tese para obtenção do título de Doutor.

X SUBMETER PROJETO AO COMITÉ DE ÉTICA Humanos

$\mathrm{X}$ Animais

CTBIO

APROVADO $\mathrm{X}$ PRORROGADO $\square$ INTERROMPIDO $\square$ CANCELADO $\square$ CONCLUÍDO

REFORMULAR $\square$ DESFAVORÁVEL:

Observação:

A Comissão de Pesquisa analisou o presente projeto de pesquisa e deliberou pela sua aprovação. Quanto aos recursos financeiros previstos para execução do projeto, esclarecemos que:

1. Os recursos para Material de Consumo, Equipamentos e Material Permanente, serão liberados mediante a solicitação do pesquisador através de $\mathrm{Cl}$ e conforme disponibilidade orçamentária da CPq/PROPP.

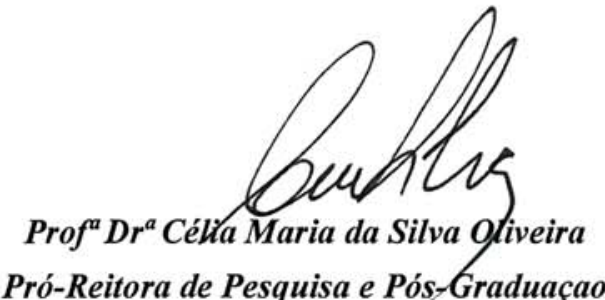

Pró-Reitora de Pesquisa e Pós-Graduaçao

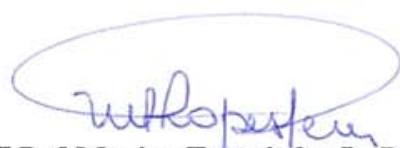

Prof $^{a}$ Dr $^{a}$ Marize Terezinha L. P. Peres

Chefe da Coordenadoria de Pesquisa/PROPP 